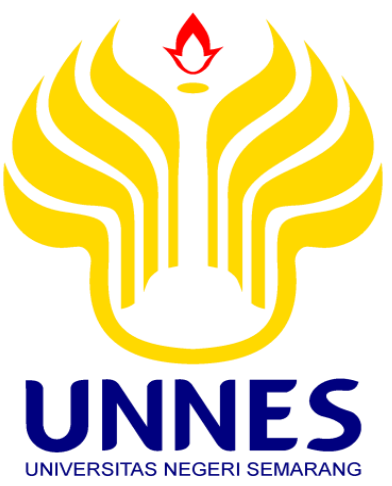

PERAN MASYARAKAT TERHADAP KESENIAN TAYUB DI DESA BEDINGIN KECAMATAN TODANAN

KABUPATEN BLORA

SKRIPSI

untuk memperoleh gelar Sarjana Pendidikan

$\begin{array}{ll} & \text { Oleh } \\ \text { Nama } & : \text { Ayu Mustika Sari } \\ \text { NIM } & : 2501409028 \\ \text { Program Studi } & : \text { Pendidikan Seni Tari } \\ \text { Jurusan } & : \text { PSDTM }\end{array}$

FAKULTAS BAHASA DAN SENI

UNIVERSITAS NEGERI SEMARANG

2016 
PERSETUJUAN PEMBIMBING

Skripsi ini telah disetujui oleh pembimbing untuk diajukan ke Sidang Panitia Ujian Skripsi.

Semarang, 6 Juni 2016

Menyetujui,

Pembimbing I

Pembimbing II
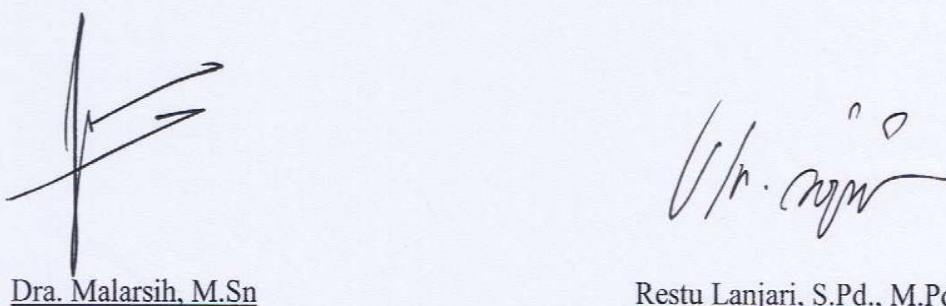

NIP. 196106171988032001

Restu Lanjari, S.Pd., M.Pd

NIP. 196112171986012001 


\section{PENGESAHAN KELULUSAN}

Skripsi ini telah dipertahankan dihadapan sidang Panitia Sidang Skripsi Jurusan Pendidikan Sendratasik, Fakultas Bahasa Dan Seni, Universitas Negeri Semarang

$$
\begin{array}{ll}
\text { Pada hari } & : \text { Selasa } \\
\text { Tanggal } & : \text { 14 Juni } 2016
\end{array}
$$

Panitia Ujian Skripsi

Prof. Dr. Agus Nuryatin, M.Hum ( 196008031989011001 ) Ketua

Dr. Udi Utomo, M.Si. ( 196708311993011001 )

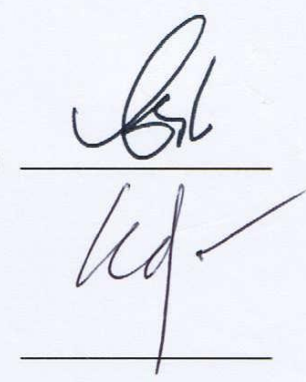

Sekretaris

Utami Arsih, S.Pd., M.A. ( 197001051998032001$)$

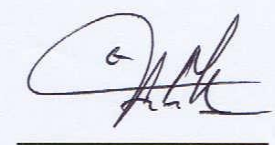

Penguji I

Restu Lanjari, S.Pd., M.Pd. ( 196112171986012001 )

Penguji II/ Pembimbing II

Dra. Malarsih, M.Sn. ( 196106171988032001 )

Penguji III/ Pembimbing I
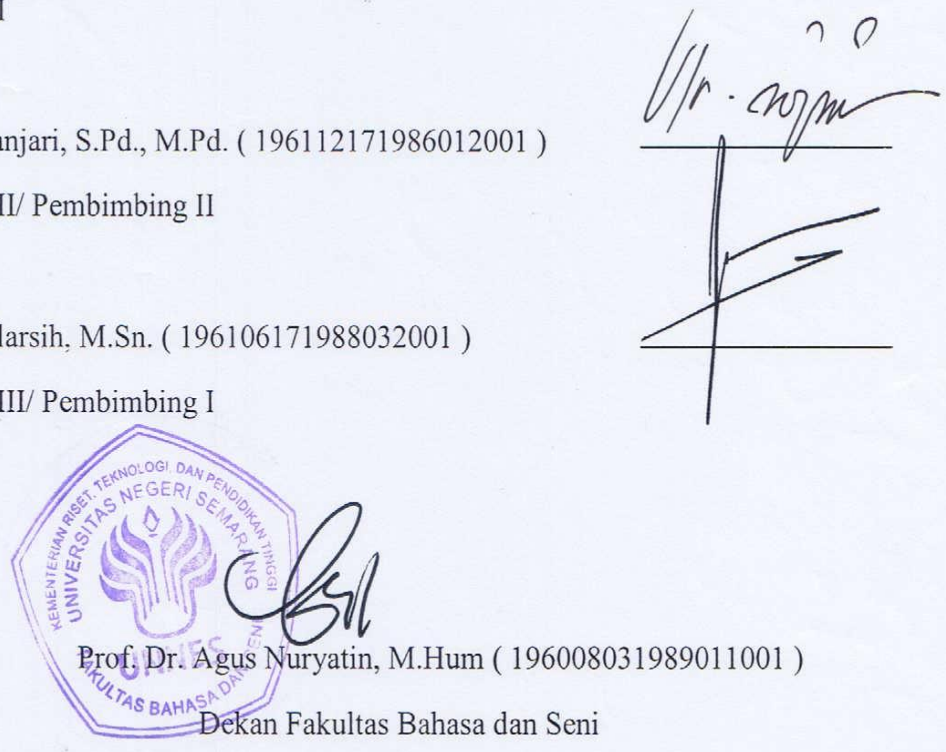


\section{PERNYATAAN}

Saya menyatakan bahwa yang tertulis di dalam skripsi ini benar-benar hasil karya saya sendiri, bukan jiplakan dari karya orang lain, baik sebagian atau seluruhnya. Pendapat atau temuan orang lain yang terdapat dalam skripsi ini dikutip atau dirujuk berdasarkan kode etik ilmiah.

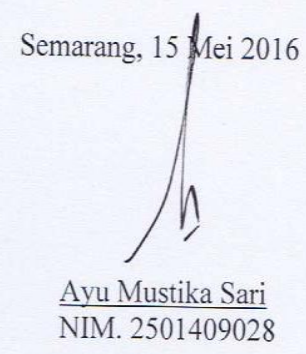

iv 


\section{MOTTO DAN PERSEMBAHAN}

1. Barang siapa menempuh suatu jalan untuk mencari ilmu maka Allah akan memudahkan padanya jalan menuju surga (H.R. Muslim)

2. Gantunglah cita-citamu setinggi langit, bermimpilah setinggi langit. Jika engkau jatuh,diantara bintang-bintang (Bung Karno)

3. Barang siapa yang tak pernah melakukan kesalahan, maka dia tidak pernah mencoba sesuatu yang baru (Albert Einstein)

Persembahan:

Skripsi ini saya persembahkan untuk

Bapakku Karyoso Rochmad, Ibuku Purwaningsih, Adikku Ayu Nila Sari 


\section{SARI}

Sari, Ayu Mustika. 2016. Peran Masyarakat Terhadap Kesenian Tayub di Desa Bedingin Kecamatan Todanan Kabupaten Blora. Jurusan sendratasik, Fakultas Bahasa dan Seni, Universitas Negeri Semarang. Pembimbing I : Dra. Malarsih, M. Sn. Pembimbing II: Restu Lanjari S.Pd M.Pd

Kata kunci: Peran Masyarakat, Kesenian, Pertunjukan Tayub.

Kesenian yang berbentuk pertunjukan Tayub Di Desa Bedingin Kecamatan Todanan Kabupaten Blora adalah sebuah kesenian rakyat yang masih sering dipentaskan dan digemari dikalangan penikmatnya, karena dalam pertunjukan perlu adanya peran masyarakat sebagai penonton, pengibing, tamu undangan dan pedagang.

Pokok masalah yang diajukan yaitu peran masyarakat terhadap kesenian Tayub di Desa Bedingin Kecamatan Todanan Kabupaten Blora dengan kajian pokok: (1) Bagaimana Bentuk Pertunjukan Tayub di Desa Bedingin Kecamatan Todanan Kabupaten Blora; (2) Bagaimana Peran Masyarakat Terhadap Kesenian Tayub di Desa Bedingin Kecamatan Todanan Kabupaten Blora.

Penelitian ini menggunakan metode kualitatif yang menghasilkan data deskriptif dengan menggunakan pendekatan sosiologi. Teknik pengumpulan data yang digunakan yaitu: wawancara, observasi dan dokumentasi.

Hasil penelitian menunjukan bahwa bentuk pertunjukan meliputi pembukaan, inti dan penutup yang terdiri dari pemain (pelaku), iringan, tata rias, tata busana dan tempat pentas. Peran masyarakat dalam pertunjukan Tayub sebagai penonton yang menyaksikan pertunjukan Tayub. Pengibing sebagai orang yang menari bersama joged. Tamu undangan sebagai penikmat Tayub yang berhubungan dengan penanggap dan pedagang yang menggelar pusat jajanan menyerupai pasar tiban di arena pertunjukan Tayub. Tujuan diselenggarakan pertunjukan Tayub untuk menghibur masyarakat Desa Bedingin serta melestarikan kesenian yang berkembang di masyarakat.

Saran dalam penelitian ini yaitu kepada Pemerintah Desa Bedingin hendaknya menyediakan wadah bagi seniman-seniman yang ada di Desa Bedingin agar lebih dapat mengembangkan bakat terutama pada kesenian Tayub. Bagi Dinas pariwisata untuk terus memperhatikan keberadaan kesenian terutama kesenian tradisional kerakyatan Tayub. Menjaga dan memelihara serta mengembangkan dengan memberikan bantuan berupa sarana dan prasarana pendukung kesenian Tayub serta didirikannya sanggar seni tari Desa Bedingin yang didalamnya terdapat kesenian Tayub, sehingga ketika ada acara hajadan tidak perlu mendatangkan atau menyewa kesenian lain, sehingga lebih ringan menggunakan swasembada masyarakat desa sendiri dan diharapkan pula dapat mempromosikan kesenian Tayub. 


\section{PRAKATA}

Alhamdulillah, Puji syukur atas kehadirat Allah SWT yang Maha Pengasih lagi Maha Penyayang. Berkat Rahmat, Hidayah dan Inayah-Nya, akhirnya saya dapat menyelesaikan skripsi untuk memenuhi sebagian persyaratan guna memperoleh gelar sarjana. Peneliti dalam menyusun skripsi ini memperoleh banyak bantuan dan bimbingan serta pengalaman dari berbagai pihak. Pada kesempatan ini peneliti mengucapkan banyak terimakasih kepada yang terhormat:

1. Prof. Dr. Fathur Rokhman, M.Hum Rektor Universitas Negeri Semarang yang telah memberikan kesempatan kuliah di UNNES.

2. Prof. Dr. Agus Nuryatin, M.Hum Dekan Fakultas Bahasa dan Seni yang telah memberikan ijin untuk melaksanakan penelitian.

3. Dr. Udi Utomo, M.Si Ketua Jurusan Pendidikan Sendratasik yang telah memberi bantuan dan kemudahan dalam penyusunan skripsi ini.

4. Dra. Malarsih, M.Sn Dosen Pembimbing 1 dan Restu Lanjari S.Pd M.Pd Dosen Pembimbing II yang telah banyak membimbing dan meluangkan waktunya untuk memberikan arahan serta saran-saran selama penyusunan skripsi.

5. Dr. Wahyu Lestari, M.Pd selaku Dosen Wali yang selalu memberikan motivasi dan semangat dalam menyelesaikan skripsi.

6. Segenap Dosen Jurusan Pendidikan Seni Drama Tari dan Musik yang telah banyak memberi bekal pengetahuan dan ketrampilan selama belajar di Universitas Negeri Semarang. 
7. Sunyoto selaku Kepala Desa dan Agil Manunggal selaku ketua paguyuban kesenian Tayub di Desa Bedingin Todanan Kabupaten Blora yang telah membantu dalam proses pengambilan data.

8. Purwaningsih ibu kandungku yang kebetulan selaku penari Tayub selalu memberikan semangat, motivasi dan dukungan serta bantuan kepada penulis dalam informasi jadwal pementasan dan pengambilan data.

9. Teman-teman seni tari angkatan 2009 dansemua pihak yang tidak dapat penulis sebutkan satu-persatu yang telah membantu dan memberikan semangat serta dukungan dalam mengerjakan skripsi.

Penulis sadar bahwa penelitian ini jauh dari kesempurnaan. Untuk itu, saran dari pembaca selalu penulis harapkan demi kesempurnaan skripsi ini. Akhirnya penulis berharap semoga skripsi ini dapat bermanfaat dan berguna bagi semua pihak. 


\section{DAFTAR ISI}

\section{Halaman}

HALAMAN JUDUL _...................................................

HALAMAN PENGESAHAN _........................................ ii

PERNYATAAN ……..................................................................

MOTTO DAN PERSEMBAHAN _........................................ iv

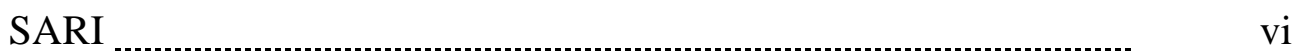

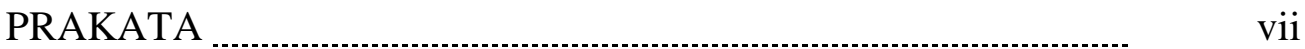

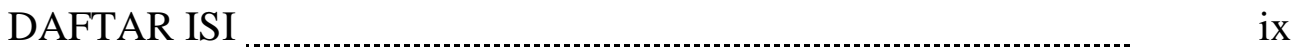

DAFTAR TABEL

DAFTAR FOTO

DAFTAR LAMPIRAN _............................................... xvi

\section{BAB I PENDAHULUAN}

1.1 Latar Belakang Masalah _.............................................. 1

1.2 Rumusan Masalah ........................................................... 3

1.3 Tujuan Penelitian _.................................................... 4

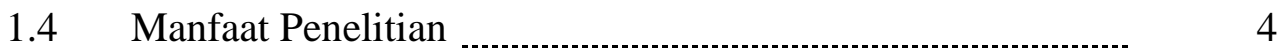

$1.5 \quad$ Sistematika Skripsi …................................................ 6

\section{BAB II TINJAUAN PUSTAKA DAN LANDASAN TEORETIS}

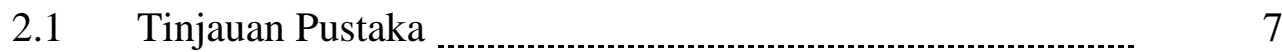

2.2 Landasan Teoretis _................................................ 10 


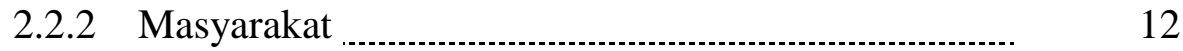

2.2.2.1 Kelompok Masyarakat ………………................... 13

2.2.2.2 Interaksi Sosial

2.2.3 Kesenian

2.2.4 Kesenian Tradisional ……............................... 19

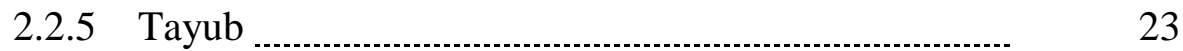

2.2.6 Bentuk Pertunjukan _........................................... 25

2.2.6.1Pemain/Pelaku

2.2.6.2 Tata Busana

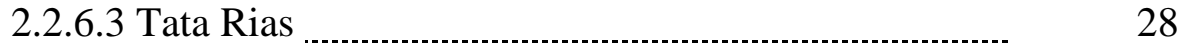

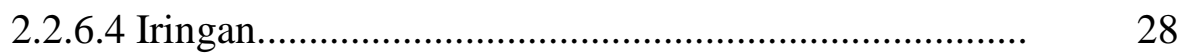

2.2.6.5 Tempat Penyajian ……......................................... 29

2.2.6.6 Pengibing _................................................ 30

2.2.6.7 Penonton

2.2.6.8 Tamu Undangan .................................................. 31

2.2.6.9 Pedagang ……....................................................

2.3 Kerangka Berfikir _......................................................... 33

\section{BAB III METODE PENELITIAN}

3.1 Pendekatan Penelitian _......................................... 35

3.2 Lokasi dan Sasaran Penelitian ……................................. 36 
3.2.1 Lokasi Penelitian

3.2.2 Sasaran Penelitian ……..................................... 37

3.3 Teknik Pengumpulan Data …….................................. 37

3.3.1 Observasi 37

3.3.2 Wawancara

3.3.3 Dokumentasi

3.4 Teknik Analisis Data 42

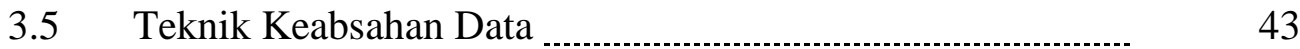

\section{BAB IV HASIL DAN PEMBAHASAN}

4.1 Gambaran Umum Lokasi Penelitian

4.1.1 Lokasi dan Kondisi Geografis Desa Bedingin …...... 44

4.1.2 Jumlah Penduduk .................................................

4.1.3 Mata Pencaharian $\quad 48$

4.1.4 Pendidikan ................................................... 40

4.1.5 Sejarah Tayub di Desa Bedingin ……..................... 54

4.2 Bentuk Pertunjukan _.............................................. 57

4.2.1 Deskripsi Pertunjukan Tayub _................................ 57

4.2.1.1 Pembukaan ……..........................................

4.2.1.2 Inti

4.2.1.3 Penutup .............................................................. 61

4.2.2 Penyajian Dalam Kesenian Tayub ……..................... 62 
4.2.2.1 Pemain Atau Pelaku ................................................. 62

4.2.2.1.1 Joged _........................................................... 62

4.2.2.1.2 Tata Rias Dan Busana 66

4.2.2.1.3 Iringan …….................................................

4.2.2.1.4 Tempat Pentas _................................................ 72

4.3 Peran Masyarakat _...................................................... 73

$\begin{array}{lll}\text { 4.3.1 Penonton } & 74\end{array}$

4.3.2 Pengibing .....................................................

4.3.3 Tamu Undangan ………........................................

4.3.4 Pedagang ............................................................... $\quad 79$

4.3.5 Penanggap .......................................................

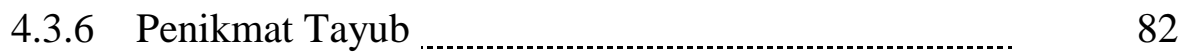

$\begin{array}{lll}\text { 4.3.7 Pendokumentasi } & 82\end{array}$

4.3.8 Operator $\ldots 3$

4.3.9 Karang Taruna _..............................................

\section{BAB V PENUTUP}

5.1 Simpulan

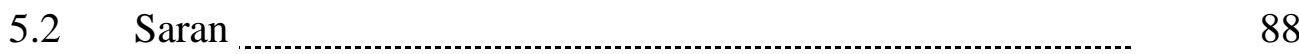

DAFTAR PUSTAKA

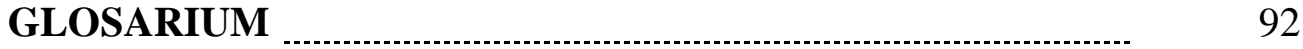

LAMPIRAN 
DAFTAR TABEL

\section{Halaman}

Tabel 1 : Jumlah penduduk Desa Bedingin menurut umur dan jenis Kelamin 46

Tabel 2 : Penduduk Desa Bedingin berdasarkan mata pencaharian 48

Tabel 3: Jumlah penduduk menurut mata pencaharian 49

Tabel 4: Jumlah penduduk Desa Bedingin menurut pendidikan 50 


\section{DATAR FOTO}

\section{Halaman}

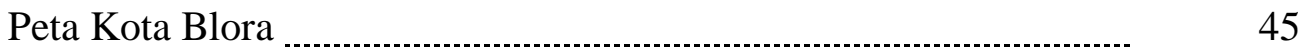

Foto 1 : Wawancara Dengan Kepala Desa _............................. 47

Foto 2 : Wawancara Dengan Bapak Kacung _..................... 52

Foto 3 : Wawancara Dengan Ibu Purwaningsih ...................... 53

Foto $4 \quad$ : Wawancara Dengan Bapak Supandri …….................. 54

Foto 5 : Gambyongan Disertai Sinden ……........................... 64

Foto 6 : Wawancara Dengan pengarih ..................................

Foto $7 \quad: \quad$ Penari Tayub _..................................................

Foto 8 : Agil, Ketua Paguyuban ………….........................

Foto $9 \quad: \quad$ Pengrawit Tayub

Foto $10 \quad$ : Tayuban

Foto 11 : Wawancara Dengan Penonton ……………................ 83

Foto 12 : Pedagang Minuman Keras 


\section{DAFTAR LAMPIRAN}

Lampiran

Halaman

Lampiran 1. Pedoman Observasi

95

Lampiran 2. Pedoman Wawancara

96

Lampiran 3. Identitas Penulis

98

Lampiran 4. Surat Penetapan Dosen Pembimbing 99

Lampiran 5. Surat Keterangan Permohonan Izin Penelitian 100

Lampiran 6. Dokumentasi Penelitian 


\section{BAB I}

\section{PENDAHULUAN}

\subsection{Latar Belakang}

Kabupaten Blora merupakan salah satu kabupaten yang berada di Propinsi Jawa Tengah. Daerah ini memiliki berbagai jenis seni pertunjukan seni tradisional, diantaranya Tayub, Barongan, Wayang Krucil, Wayang Kulit, Kentrung dan Kethoprak. Disamping itu juga hidup dan berkembang bentuk seni pertunjukan lain seperti: Dangdut, Campursari serta Organ Tunggal. Salah satu diantaranya yang cukup terkenal di wilayah Kabupaten Blora adalah kesenian Tayub.

Kesenian Tayub adalah salah satu bentuk seni pertunjukan tradisional yang tumbuh dan berkembang dengan subur di Kabupaten Blora. Pertunjukan Tayub yang berkembang di Blora memiliki bentuk yang hampir sama dengan bentuk pertunjukan Tayub yang berkembang di daerah lain, seperti: Purwodadi, Rembang, Pati, dan Sragen.

Pigeaud dalam Centhini (1985:37) berpendapat bahwa Tayub berkembang di lingkungan Keraton dan lingkungan rakyat. Tayub dalam lingkungan masyarakat keraton diwujudkan dalam pelembagaan tari Bedaya, sedangkan masyarakat pedesaan dapat diungkapkan dalam palembagaan tari Tayub. Jenis tari Bedaya yang sampai sekarang masih sering dipentaskan di lingkungan istana sebagai tarian ritual, mengandung makna adanya kekuatan atau magis bagi kemakmuran dan kesejahteraan raja beserta kawulanya. Begitu pula Tayub yang diadakan dalam rangkaian bersih desa di lingkungan masyarakat pedesaan 
merupakan ritus kesuburan yang diharapkan dapat mempengaruhi kesuburan tanah pertanian (Hadi, 2005:43).

Tayub sebagai bagian dari upacara yang terkait dengan simbol kesuburan yang melambangkan hubungan seksual antara laki-laki dan perempuan atau lambang pertemuan lingga (alat kelamin laki-laki) dan yoni (alat kelamin perempuan), dipercaya mempunyai kekuatan magis simpatetis yang mampu menyuburkan tanah dan alam. Upacara ritual bertujuan agar yang diselenggarakan lebih meriah (Skripsi Umami, 2013:2).

Kesenian Tayub merupakan bentuk pertunjukan tari rakyat yang disajikan oleh penari perempuan atau ledhek diiringi dengan seperangkat gamelan berlaras selendro atau pelog disertai tembang, serta dipertunjukkan di atas panggung, pendapa atau halaman. Pertunjukan Tayub melibatkan penonton terutama laki-laki untuk berpartisipasi langsung menjadi pasangan penari Tayub dalam menari di atas pentas. Oleh karena itu tari berpasangan Tayub mempunyai sifat erotis yang diwarnai dengan sensualitas dan seksualitas yang disebut sebagai simbol kesuburan Rohana (dalam Tesis 2009:291).

Kesenian Tayub Di Kabupaten Blora terdapat dua bagian, yaitu bagian kulon Kecamatan Todanan dan bagian wetan Kecamatan Jepon (Dinas Pariwisata Kabupaten Blora). Bentuk pertunjukannya sama, perbedaan terdapat pada kostum ledhek.

Desa Bedingin merupakan salah satu desa yang luas, terletak di pinggiran atau perbatasan diantara Kabupaten Pati dan Kabupaten Blora. Jumlah penduduknya sangat padat, sebagian besar mayoritas bekerja sebagai petani, 
namun tidak sedikit diantaranya yang ikut serta menjadi anggota seniman, baik dalam kesenian Tayub, Barongan maupun Dangdut. Beberapa kesenian tersebut biasa dipetaskan dengan membutuhkan antusias masyarakat untuk ikut meramaikan atau memeriahkan acara pertunjukan, masyarakat bisa dari desa maupun dari luar Desa Bedingin,maka dari itu peran masyarakat sangatlah penting keberadaannya, karena kesenian tidak akan bertahan hidup tanpa adanya dukungan dari masyarakat. Diantara kesenian yang ada di Desa Bedingin, peneliti tertarik untuk meneliti salah satu kesenian yaitu Tayub yang berada di Desa Bedingin khususnya mengenai peran masyarakatnya, karena pertunjukan Tayub sering disewa di Desa Bedingin. Hal ini dibuktikan Tayub masih sering dipentaskan dan digemari dikalangan penikmatnya.

\subsection{Rumusan Masalah}

Berdasarkan latar belakang yang sudah diuraikan diatas, maka permasalahan yang diangkat dalam penelitian ini adalah:

1.2.1 Bagaimana bentuk pertunjukan kesenian Tayub di Desa Bedingin Kecamatan Todanan Kabupaten Blora?

1.2.2 Bagaimana peran masyarakat terhadap kesenian Tayub di Desa Bedingin Kecamatan Todanan Kabupaten Blora.

\subsection{Tujuan Penelitian}

Permasalahan tentang peran masyarakat terhadap kesenian Tayub di Desa Bedingin Kecamatan Todanan Kabupaten Blora adalah sebagai berikut :

1.3.1 Mengetahui dan mendeskripsikan bentuk pertunjukan kesenian Tayub Di Desa Bedingin Kecamatan Todanan Kabupaten Blora. 
1.3.2 Mengetahuidan mendeskripsikan peran masyarakat terhadap kesenian Tayub di Desa Bedingin Kecamatan Todanan Kabupaten Blora.

\subsection{Manfaat Penelitian}

Adapun manfaat yang dapat diambil dari hasil penelitian tentang peran masyarakat terhadap kesenian Tayub di Desa Bedingin Kecamatan Todanan Kabupaten Blora adalah sebagai berikut :

\subsubsection{Manfaat Teoritis}

Manfaat teoritis yaitu manfaat yang tidak langsung meliputi :

1.4.1.1 Penelitian ini diharapkan bermanfaat untuk menambah khasanah pengetahuan dalam bidang seni khususnya pada peran masyarakat terhadap kesenian Tayub di Desa Bedingin Kecamatan Todanan Kabupaten Blora.

1.4.1.2 Memberikan wawasan dan pertimbangan bagi peneliti yang akan meneliti penelitian sejenis.

\subsubsection{Manfaat Praktis}

Manfaat praktis yaitu manfaat yang secara langsung, meliputi:

1.4.2.1 Sebagai bahan dokumentasi serta sebagai bahan informasi yang lengkap bagi masyarakat yang memiliki rasa peduli terhadap kesenian tradisional, sehingga dapat tercapainya peran masyarakat terhadap kesenianTayub di Desa Bedingin Kecamatan Todanan Kabupaten Blora.

1.4.2.2 Bagi generasi muda dapat memberikan inspirasi untuk ikut serta mewarisi dan melestarikan kesenian tradisional. 
1.4.2.3 Bagi mahasiswa, diharapkan hasil penelitian ini berguna sebagai bahan informasi terutama bagi Mahasiswa Universitas Negeri Semarang.

1.4.2.4 Bagi Departemen Pendidikan dan kebudayaan Kabupaten Blora, hasil penelitian ini dapat menambah sumber informasi sehingga dapat dijadikan dasar pertimbangan dalam menjaga kelestarian seni pertunjukan Tayub.

\subsection{Sistematika Penulisan Skripsi}

Keseluruhan uraian rangkaian di atas dipermudah dengan adanya sistematika, penelitian skripsi ini dibagi menjadi tiga bagian yaitu : bagian awal berisi halaman judul, halaman pengesahan, halaman motto, dan persembahan, prakata, daftar isi, daftar lampiran. Bagian isi terbagi atas lima Bab yaitu:

Bab I : Pendahuluan, yang berisi tentang Latar Belakang Masalah, Rumusan Masalah, Tujuan Penelitian, Manfaat Penelitian dan Sistematika Skripsi.

Bab II : Tinjauan Pustaka pada Bab ini akan diuraikan tentang bentuk dan peran masyarakat terhadap kesenian Tayub di Desa Bedingin Kecamatan Todanan Kabupaten Blora.

Bab III : Metode penelitian, berisi tentang pendekatan penelitian, tekhnik pengumpulan data (observasi, wawancara dan dokumentasi) dan analisis data.

BabIV : Hasil penelitian dan pembahasan yang mencakup tentang lokasi penelitian, bentuk penyajian Tayub dan pembahasan tentang peran masyarakat terhadap kesenian Tayub di Desa Bedingin Kecamatan Todanan Kabupaten Blora. 
BabV : Penutup berisi Simpulan dan Saran.

Bagian akhir skripsi berisi Daftar Pustaka dan Lampiran-Lampiran 


\section{BAB II}

\section{TINJAUAN PUSTAKA DAN LANDASAN TEORETIS}

\subsection{Tinjauan Pustaka}

Penelitian serupa pernah dilakukan oleh Afriza Fitri Umami tahun 2013 dengan judul "Peran Pengibing Dalam Pertunjukan Tayub Di Desa Kemiri Kecamatan Jepon Kabupaten Blora”. Penelitian Afriza dan penelitian yang dilakukan peneliti sama-sama meneliti Tayub di Kabupaten Blora, Perbedaan Afriza meneliti peran pengibing, sedangkan peneliti tentang peran masyarakat yang terdiri dari pengibing, penonton, tamu undangan dan pedagang.

Penelitian yang diambil Afriza memiliki perbedaan dengan penelitian yang akan dilakukan oleh peneliti, penelitian tersebut membahas tentang bentuk pertunjukan dan peran pengibing dalam kesenian Tayub di Desa Kemiri Kecamatan Jepon Kabupaten Blora, sedangkan peneliti ingin meneliti bentuk pertunjukan dan peran masyarakat terhadap kesenian Tayub yang berada di Desa Bedingin Kecamatan Todanan Kabupaten Blora.

Hasil penelitian Afriza mengatakan bentuk pertunjukan Tayub diawali dengan joged menari gambyong, selanjutnya ucapan selamat datang oleh kepala Desa (Pambagyoharjo) kemudian inti pertunjukan dengan melakukan slisig, kemudian bawa, dilanjutkan ngibing akhir pertunjukan ditandai degan lelagon lancarangendhing pamitan dilanjutkan pamungkas. Peran pengibing dalam pertunjukan Tayub yang meliputi: (1) peran pengibing sebagai penari pada pertunjukanTayub di Desa Kemiri Kecamatan Jepon Kabupaten Blora; (2) 
Pengibing sebagai pelengkap pertunjukan Tayub; (3) Pengibing sebagai sarana interaksi sosial.

Kesimpulan dari penelitian Afriza adalah kesenian Tayub tidak akan berhasil tanpa adanya masyarakat, karena tujuan dari diselenggarakan pertunjukan Tayub guna menghibur para masyarakat serta melestarikan kesenian yang tumbuh didalam masyarakat.

Penelitian peran juga pernah dilakukan oleh Sri Rochana tahun 2007 dengan judul "Peran Penari Perempuan Dalam Tari Tayub Di Blora Jawa Tengah Sebuah Pendekatan Etnokoreologi”. Penelitian Sri Rochana dan penelitian yang dilakukan peneliti sama-sama meneliti Tayub di Kabupaten Blora, Perbedaan Sri Rochana meneliti peran penari sebagai pelaku atau pemain, sedangkan peneliti tentang peran masyarakatnya.

Penelitian yang diambil Sri Rochana memiliki perbedaan dengan penelitian yang akan dilakukan oleh peneliti, penelitian tersebut membahas tentang peran penari Tayub dan fungsi masyarakat dalam kesenian Tayub di Blora Jawa Tengah. Peneliti ingin meneliti bentuk pertunjukan dan peran masyarakat, terhadap kesenian Tayub yang berada di Desa Bedingin Kecamatan Todanan Kabupaten Blora.

Hasil Penelitian didalamnya membahas tentang peran penari Tayub (Joged) yang berperan penting dalam dunia hiburan, tak terkecuali dalam bidang tari Tayub dan fungsi di dalam masyarakat Blora. Peran penari Tayub dalam rumah tangga sebagai tulang punggung keluarga dan sebagai ibu rumah tangga. Tayub berfungsi sebagai salah satu kesenian yang menjadi sumber mata 
pencaharian, Tayub juga berfungsi didalam masyarakat Blora sebagai hiburan. Fungsi masyarakat dalam Tayub sebagai pemeriah acara tari Tayub, karena masyarakat berperan sebagai pengibing dan penonton dalam acara pertunjukan Tayub di Blora, agar tari Tayub dapat meriah dan berjalan lancar. Penelitian juga memaparkan aspek pertunjukan yang meliputi tata rias dan tata busana.

Kesimpulanya bahwa masyarakat sebagai fungsi yang sangat penting dalam acara pertunjukan Tayub di Blora. Masyarakat sebagai pemeriah acara pertunjukan Tayub yang tidak dapat ditinggalkan, karena pertunjukan tidak akan berjalan lancar tanpa adanya masyarakat.

Penelitian yang didalamnya membahas peran juga pernah ditulis oleh Desy Cahyaningtyas tahun 2013 dengan judul Penyajian Dalam Upacara Apitan Di Desa Tanggel Kecamatan Winong Kabupaten Pati. Penelitian Dessy dan penelitian yang dilakukan peneliti sama-sama meneliti tentang peran masyarakat dalam Tayub, Perbedaan terdapat dari penelitian Desy meneliti tentang peran masyarakat sebagai penyelenggaraan Tayubandi Desa Tanggel Kecamatan Winong Kabupaten Pati, sedangkan peneliti meneliti tentang peran masyarakat terhadap kesenian Tayub yang berada di Desa Bedingin Kecamatan Todanan Kabupaten Blora.

Penelitian yang diambil Dessy memiliki perbedaan dengan penelitian yang akan dilakukan oleh peneliti, Penelitian tersebut membahas tentang bentuk penyajian dalam upacara Apitan dan peran serta masyarakat dalam penyelenggaraan Tayuban pada upacara apitan di Desa Tanggel Kecamatan Winong Kabupaten Pati. Sedangkan peneliti ingin meneliti tentang bentuk 
pertunjukan dan peran masyarakat terhadap kesenian Tayub yang berada di Desa Bedingin Kecamatan Todanan Kabupaten Blora.

Hasil penelitian mengungkapkan bahwa seni Tayub di Desa Tanggel Kabupaten Pati disajikan secara utuh dari awal hingga akhir upacara Apitan. Penyajian yang memfokuskan pada bentuk pertunjukan yang terdiri dari pemain (pelaku), gerak, iringan, tata rias, tata busana dan tempat pentas. Tayub dalam upacara Apitan merupakan sebagai sarana ritual yang sangat penting dan tidak boleh ditinggalkan karena dapat menimbulkan musibah pada Desa Tanggel. Upacara didukung masyarakat setempat dengan peran dan upaya dalam bentuk tenaga dan materi, sedangkan masyarakat disaat sajian Tayuban berperan sebagai penayub dan penonton yang membuat acara semakin meriah.

Kesimpulannya bahwa peran masyarakat sebagai pendukung terpenting dalam pementasan kesenian Tayub, karena tanpa adanya masyarakat kesenian Tayub tidak akan berjalan lancar dan tidak akan terjadi pada Pertunjukan Tayub.

Paparan tentang pertunjukan Tayub yang peneliti uraikan di atas, merupakan salah satu alasan yang mendorong peneliti mengkaji peran masyarakat terhadap kesenian Tayub di Desa Bedingin Kecamatan Todanan Kabupaten Blora.

\subsection{Landasan Teoretis}

\subsubsection{Peran}

Peran adalah perangkat tingkat yang diharapkan, dimiliki oleh orang yang berkedudukan dimasyarakat dan dalam dunia akting peran adalah pemain sandiwara (Soekamto, 2001:17). Pendapat peran adalah satu set yang tersambung yaitu perilaku hak dan kewajiban seperti yang dikonseptualisasikan oleh pelaku 
dalam situasi sosial. Hal ini terus menerus mengubah perilaku yang diharapkan dan memiliki individu yang diberikan kepada status sosial atau posisi sosial.

Menurut Poerwodarminto (2005:381) kata peran yang berarti pemain sandiwara tukang lawak pada pemain Ma'yung. Peran didefinisikan sebagai perilaku yang diharapkan dari status yang dimiliki oleh seseorang. Artinya seseorang yang dimiliki status tertentu seharusnya juga memiliki peran sesuai dengan status yang disandangnya (Soeroso, 2008:17). Peran aspek dinamis dari kedudukan (status) apabila seseorang melaksanakan hak dan kewajibannya sesuai dengan kedudukannya, maka dia menjalankan suatu peran (Soekanto, 1991:268).

Peran perempuan sebagai ibu merupakan sangkan paraning dumadi yang berarti tempat dan berakhirnya kehidupan. Identitas perempuan sebagai ibu, dipercaya mampu menjalankan proses sosialisasi terhadap anak-anak tentang nilai-nilai kultural, kebenaran, hingga penghayatan atas rasa kemanusiaan. Tumpuan ibu sebagai pengasuh, pendidik dan menolong tersebut dipasangkan dengan fungsi lainya sebagai istri. Sebagai seorang pedamping, perempuan juga memiliki tanggung jawab untuk berpartisipasi aktif dalam menjaga relasinya dengan suami, hal inilah yang tercermin pada kehidupan perempuan pedesaan. Penguasaan perannya sebagai ibu dan istri senantiasa dimanifestasikan dalam pergumulan simbol-simbol dunia privat dan publik, sebab demi kelangsungan hidup keluarga, perempuan tidak dapat hanya berkutat pada tugas domestik, melainkan juga tampil dalam arena publik mengolah tanah pertanian Asriani (dalam Ismawati 2005:35). 
Beberapa pengertian di atas dapat disimpulkan bahwa peran adalah perilaku yang diharapkan, contoh adalah perempuan pedesaan yang berperan sebagai ibu yang melakukan hak dan kewajibanya menjalankan proses sosialita terhadap anak-anak.

\subsubsection{Masyarakat}

Pengertian masyarakat berasal dari bahasa Arab syakara yang berarti ikut serta, berpatisipasi (Koenjaraningrat, 2000:143-144). Masyarakat memiliki arti sekelompok orang yang membentuk sebuah sistem semi tertutup atau terbuka. Masyarakat terdiri atas individu-individu yang saling tergantung satu sama lain atau disebut zoon polition. Masyarakat dalam Bahasa Inggris disebut dengan istilah society yang berasal dari kata latin socius yang berarti kawan.

Menurut Kamus Besar Bahasa Indonesia, masyarakat adalah sejumlah manusia yang terikat oleh suatu kebudayaan. Definisi masyarakat adalah suatu keseluruhan kompleks hubungan manusia yang luas sifatnya. Keseluruhan yang kompleks sendiri berarti bahwa keseluruhan itu terdiri atas bagian-bagian yang membentuk suatu kesatuan (Peter, 1991:46). Menurut Mark (1996:22) masyarakat ialah keseluruhan hubungan-hubungan ekonomis, baik produksi maupun konsumsi yang berasal dari kekuatan-kekuatan produksi ekonomis, yakni teknik dan karya. Pengertian diatas dapat disimpulkan bahwa pengertian masyarakat adalah orang-orang yang hidup bersama dan menghasilkan kebudayaan.

Masyarakat adalah kesatuan hidup manusia yang berinteraksi menurut suatu sistem adat-istiadat tertentu yang bersifat kontinu dan terikat oleh suatu rasa identitas bersama. Masyarakat disebutkan dalam arti masyarakat luas dan sempit, 
masyarakat luas contohnya masyarakat se-Indonesia, sedangkan masyarakat yang sempit yaitu masyarakat yang terdiri dari suatu warga atau berkelompok yang hidup di desa atau kota yang terikat dalam kesatuan-kesatuan khusus (Koenjaraningrat, 2000:150-155).

\subsubsection{Kelompok Masyarakat}

Kelompok masyarakat merupakan kelompok yang berisi orang-orang yang memiliki kesadaran berorganisasi. Menurut Geertz (1989) mengidentifikasi masyarakat Jawa berdasarkan tipe keagamaan menjadi tiga golongan yaitu Abangan, Santri dan Priyayi. Ketiga tipe keagamaan tersebut memiliki karakteristik yang berbeda.

\subsection{Abangan}

Memiliki tradisi keagamaan yang berupa pesta keupacaraan yang disebut dengan selamatan. Kepercayaan yang kompleks dan rumit terhadap makhluk halus, dan seluruh rangkaian teori dan praktik pengobatan, sihir dan magis serta dihubungkan dengan elemen petani. Abangan identik dengan penyelenggaraan pesta upacara atau selamatan. Selamatan adalah versi Jawa yang barangkali merupakan upacara keagamaan yang paling umum didunia. Selamatan melambanggakan kesatuan mistis dan sosial dari para peserta selamatan. Saudara, tetangga, rekan kerja, sanak keluarga, arwah nenek moyang yang sudah mati duduk bersama dan terikat dalam kesatuan sosial. Selamatan merupakan wadah bersama bagi masyarakat yang mempertemukan berbagai aspek kehidupan sosial dan pengalaman seseorang, dengan suatu cara yang memperkecil ketidakpastian, ketegangan dan konflik. Selamatan digunakan untuk acara kelahiran, kematian, 
ganti nama dan selamatan desa. Selain itu golongan Abangan memiliki kepercayaan terhadap makhluk halus seperti memedi, lelembut, thuyul, dhemit dan danyang. Istilah Islam Abangan merupakan sebutan untuk pemeluk Islam di Jawa yang tidak begitu memperhatikan perintah Agama Islam dan kurang memenuhi kewajiban Agamanya (Geertz dalam Alkaf 2009:47).

\subsection{Santri}

Tradisi keagamaan golongan santri yaitu pelaksanaan peribadatan Islam sembahyang, haji, puasa, keseluruhan yang kompleks dari organisasi sosial, kedermawaan dan politik Islam serta dihubungkan dengan elemen dagang Golongan santri menjalankan ajaran-ajaran berdasarkan Al-Qur'an dan Hadits. Pada golongan santri cenderung mengarah pada titik berat keharusan keimanan dan keyakinan terhadap kebenaran mutlak. Agama Islam serta sikap toleran yang tegas pada kepercayaan dan praktik kejawen. Golongan santri dibagi menjadi dua yaitu santri konservatif dan santri modernis. Santri konservatif ini adalah dari kalangan Muhammadiyah. Golongan santri menurut Maliki (2004:356) sebagai simbol kelas yang tidak memegang kekuasaan penting atau strategis atau wong ndhek-ndhekan. Dikalangan santri agama lebih dipandang sebagai refleksi dari kesadaran religiunitas Maliki (2004:355).

\subsection{Priyayi}

Priyayi menurut istilah aslinya merujuk pada seseorang yang bisa menelusuri asal-usul keturunannya kepada Raja-Raja besar Jawa sebelum masa penjajahan Belanda. Priyayi menekankan pada aspek Hindu dan elemen birokrasi. Golongan priyayi sudah lepas dari ikatan keraton atau sudah bukan pada raja 
melainkan kepada pemerintah kolonial. Golongan priyayi menjadi pembentuk sekera baru dari kebudayaan Koentowijoyo (2006:34). Menurut Maliki (2004:356) golongan priyayi sebagai simbol kelas yang memegang kekuasaan strategis atas wong ndhuwuran. Kalangan priyayi, penggunaan simbol-simbol agama tidak bercorak orgaris, sehingga tidak ada formalitas kebijakan maupun rekrutmen pejabat atas dasar preferensi keagamaan (Maliki 2004:353).

Masyarakat petani merupakan bagian dari masyarakat kelas menegah ke bawah, yang tidak cukup memiliki kapasitas untuk memenuhi kebutuhan hidupnya meskipun telah memproduksi barang konsumsinya sendiri (subsisten). Masyarakat pedesaan banyak mempunyai peranan aktif dalam kegiatan ekonomi seperti beternak, berdagang dan bertani. Keterlibatan mereka sangat dipengaruhi oleh sistem sosial dimana hubungan laki-laki dan perempuan di Jawa itu saling mengisi. Asriani (2010:2).

Kesimpulan dari beberapa pendapat di atas masyarakat merupakan satu kesatuan atau sekumpulan orang yang hidup bersama dalam suatu kerukunan dan saling berinteraksi satu sama lain. Baik dalam masyarakat pedesaan maupun masyarakat perkotaan tanpa membedakan golongan Abangan, Santri dan Priyayi.

\subsubsection{Interaksi Sosial}

Interaksi sosial mengandung makna tentang kontak secara timbal balik atau interstimulasi dan respon antara individu-individu dan kelompok-kelompok (Taneko,1993:110 dalam Wadiyo, 2006:142). Interaksi sosial oleh Young dan Raymond (dalam Soekanto, 1990:67) diartikan sebagai hubungan sosial yang dinamis yang menyangkut hubungan-hubungan sosial yang dinamis yang 
menyangkut hubungan antara orang perorangan, antara kelompok-kelompok manusia, maupun antara orang perorangan dengan kelompok manusia. Bertrand (dalam Faisal, 1980:28) mengartikan interaksi sosial sebagai suatu hubungan timbal balik yang telah menampilkan aksi dan reaksi diantara orang-orang yang berhubungan. Koentjaningrat (dalam Taneko, 1993:110) menjelaskan interaksi sosial adalah suatu reaksi seseorang atau kelompok orang akibat adanya aksi dari pihak lain.

Berkesenian dapat dipahami sebagai bentuk melakukan kegiatan seni. Kegiatan dalam seni bisa dilakukan secara aktif tapi juga bisa dilakukan secara pasif. Dilakukan secara aktif dapat dimengerti sebagai pelaku melakukan reaksi, seperti melukis atau menggambar, memainkan instrumen musik dan menari (Wadiyo,2006:144).

Interaksi sosial menurut Polhaupessy (1998:28) adalah perilaku atau Tanggapan Reaksi. Sebuah gerakan yang dapat diamati dari luar, seperti orang berjalan, naik sepeda dan mengendarai motor atau mobil. Sikap dikatakan sebagai suatu respons evaluasi, respon hanya akan timbul apabila individu dihadapkan pada suatu stimulus yang dikehendaki adanya reaksi individual. Respon evaluatif berarti bahwa bentuk reaksi yang dinyatakan sebagai sikap itu timbul didasari oleh proses evaluasi dalam diri individu yang memberi kesimpulan terhadap stimulus dalam bentuk nilai baik buruk, positif negatif, menyenangkan-tidak menyenangkan, yang kemudian mengkristal sebagai potensi reaksi terhadap objek sikap (Azwar, 2000:15). Perilaku merupakan bentuk tindakan nyata seseorang sebagai akibat dari adanya aksi respon dan reaksi. 
Kegiatan seni secara pasif, dimengerti sebagai suatu kegiatan berkesenian tapi hanya dilakukan dengan mengapresiasi tanpa menghasilkan bentuk karya apapun yang bisa dinikmati atau dimengerti orang lain.

Pengertian di atas dapat disimpulkan apabila dikaitkan dengan peran masyarakat dalam pertunjukan Tayub bahwa berkesenian secara aktif dapat diartikan masyarakat berinteraksi dan saling berekspresi secara langsung dengan menari bersama ledhek sebagai pengibing dan juga sebagai penikmat pertunjukan. Berkesenian secara pasif yaitu penikmat seni tidak terjun langsung menari bersama joged, melainkan menonton pertunjukan Tayub tanpa berekspresi apapun yang bisa dilihat orang lain. Interaksi sosial merupakan saling ketergantungan satu sama lain yang berhubugan saling mendukung dalam kebersatuan, untuk itu masyarakat diharapkan mampu bekerjasama, saling menghormati. Pengertian tersebut, dapat dimengerti dengan respon timbal balik antar individu maupun kelompok.

\subsubsection{Kesenian}

Menurut Idris dalam Muhtar (2010:34) Seni memiliki karya yang diciptakan dengan keahlian luar biasa. Seni adalah rasa keindahan dan diciptakan untuk melanjutkan perasaan-perasaan tersebut. Seni merupakan penjelmaan rasa indah yang terkandung dalam jiwa orang, dilahirkan dengan perantara alat-alat komunikasi dalam bentuk yang dapat ditangkap oleh indra pendengar (Suara), indra penglihat (Rupa), atau dilahirkan dengan gerak (Ensiklopedia Indonesia, 1992:3080). Menurut Sunarto dalam Muhtar (2010:34) dalam hal kodratesensial dan fungsi dari seni terdapat 3 teori yaitu bentuk hakiki merupakan salah satu sifat 
yang penting bagi seni, seni sebagai ekspresi dari perasaan manusia dan seni lebih berfungsi sebagai simbol daripada ekspresi.

Kesenian dibagi menjadi dua yaitu kesenian modern dan kesenian tradisional. Kesenian tradisional sebagai unsur kebudayaan dalam berbagai keragaman perwujudannya senantiasa terkait dengan penggunaan kaidah-kaidah dan simbol-simbol. Perwujudan karya seni dapat merupakan ekspresi yang bermakna individual, sosial, maupun budaya yang bermuatan isi sebagai substansi ekspresi yang merujuk kepada berbagai tema, interpretasi, atau pengalaman tertentu. Karya seni berisikan pesan dalam idiom komunikasi dan rangsangan perasaan misteri, yaitu sebuah perasaan yang lebih dalam dan kompleks daripada apa yang tampak dari luar (Bohanan dalam Aesijah, 2011:24).

Kesenian merupakan simbol dari masyarakat dan mengandung nilai-nilai yang hidup didalam masyarakat. Kesenian tradisional dibagi menjadi dua macam yaitu kesenian tradisional klasik dan kesenian tradisional kerakyatan. Kesenian tradisional kerakyatan disebut pula seni rakyat. Seni rakyat merupakan suatu seni yang hidup ditengah-tengah masyarakat secara turun menurun. Tradisi kerakyatan ini terlahir dengan sendirinya, namun diterima sebagai pemiliknya, bahkan diakui sebagai norma-norma yang dituruti, Bastosmi (dalam Rochmiyatun, 2009: 18-19).

Paparan di atas dapat disimpulkan bahwa kesenian tidak dapat berkembang sendiri tanpa dukungan masyarakat, maka dari itu peneliti tertarik untuk mengkaji peran masyarakat dalam kesenian Tayub. 


\subsubsection{Kesenian Tradisional}

Menurut Kayam, kesenian tradisional terjalin rapat dengan ritus keagamaan dan kemasyarakatan, ia mencerminkan secara setia dan hampir secara harfiah denyut nadi masyarakat itu (Khayam, 1981:25).

Kata tradisional merupakan istilah yang berasal dari kata tradisi, sedangkan kata tradisi berasal dari bahasa latin tradisional, yang berarti mewariskan (Rosjid, 1979:5). Warisan ini kemudian diturunkan dari generasi kegenerasi melalui proses, jadi dengan kata lain tradisi artinya warisan budaya dari masa lalu ke masa sekarang. Hal itu dapat berupa pandangan hidup, kepercayaan, kesenian, upacara adat dan sebagainya.

Sinaga (dalam Harmonia, 2007:71) menjelaskan bahwa kesenian tradisional merupakan bentuk seni yang bersumber dan berakar serta telah disarankan sebagai milik sendiri oleh masyarakat dilingkungannya. Kehidupan dan pengolahan seni tradisional didasarkan atas cita rasa masyarakat pendukungnya, meliputi pandangan hidup, nilai kehidupan tradisi, rasa etis, estetis serta ungkapan budaya lingkungan yang kemudian diwariskan pada generasi berikutnya. Kesenian sebagai salah satu cabang budaya yang berkaitan dengan cita rasa merupakan hasil budi daya manusia, menurut kodratnya manusia yang hidup akan selalu mengenal keindahan.

Kesenian tradisional merupakan ungkapan batin yang dinyatakan dalam bentuk simbolis menggambarkan arti kehidupan penduduknya. Oleh karena itu nilai yang terkandung dalam kesenian tradisional adalah nilai-nilai yang bersumber dari pandangan hidup masyarakat pendukungnya (Bastomi, 1998:16). 
Sedyawati (1991:119) mengemukakan bahwa pengertian seni tradisi bisa dilihat dari dua arah, yaitu:

2.2.4.1 Seni tradisi dapat diartikan sebagai kesenian yang diselenggarakan demi kelangsungan suatu tradisi yang menjadi pokok, sedangkan kesenian hanya sebagai sarana penunjang dengan kata lain kesenian merupakan alat penguat tradisi.

2.2.4.2 Seni tradisi bisa dimaksudkan sebagai bentuk-bentuk kesenian yang memiliki tradisi.

Predikat dapat diartikan segala yang sesuai dengan tradisi, perjalanan sejarah cukup lama dan selalu bertumpu pada pola-pola tradisi yang telah ada.

Uraian di atas maka dapat disimpulkan bahwa yang dimaksud dengan kesenian tradisional adalah kesenian yang merupakan bentuk seni warisan yang terdahulu di turunkan dari generasi ke generasi telah mengalami perjalanan sejarah cukup lama.

Kesenian tradisional dibagi menjadi dua yaitu kesenian tradisional klasik dan kesenian tradisional kerakyatan.Kesenian Tayub merupakan kesenian rakyat.

\subsection{Kesenian Klasik}

Hadi (2005:62-63) menjelaskan istilah klasik yang telah disebutkan, dalam pelembagaan tari menjadi sebutan untuk membedakan dengan istilah kerakyatan. Dua istilah antara tradisional klasik dan tradisional kerakyatan sering menjadi perbedaan yang cukup tajam apabila seni klasik dengan predikat (adi luhung), halus (politess) dan dianggap selesai (finesse). Sementara kesenian rakyat dianggap kasar, tidak selesai dan kadang berupa tiruan atau mengambil beberapa 
unsur dari kesenian yang lebih baku. Pelembagaan tari tradisional kerakyatan didukung oleh kebersamaan masyarakat pedesaan, sementara pelembagaan tari tradisional klasik hidup di lingkungan istana dengan perlindungan kekuasaan raja.

Bentuk tarian istana merupakan salah satu simbol budaya dimana tarian itu lahir, tumbuh dan berkembang. Bentuk-bentuk tari yang menduduki fungsi khusus dalam masyarakat istana ternyata sangat kompleks dan sangat banyak jenisnya. Sebagai contoh tari Bedhaya dan tari Srimpi (Jazuli, 2001:69).

\subsection{Kesenian Rakyat}

Kesenian rakyat dikonsumsi oleh masyarakat, terutama yang memiliki ikatan dengan kesenian rakyat itu. Masyarakat yang membutuhkan pelarian sejenak dari monotoni kehidupan mereka sehari-hari. Seni rakyat tumbuh dari kalangan rakyat secara langsung lantaran dari masyarakat kecil saling mengenal secara akrab, bentuknya sederhana (Jenifer, 1991:44).

Sementara itu kesenian tinggi adalah kesenian kaum elite yang tumbuh dan berkembang bersama penghalusan nilai-nilai sosial budaya istana. Dalam hal ini sesungguhnya kesenian itu berfungsi untuk mengikat solidaritas terhadap kelangsungan hidup dari istana sebagai pusat kekuasaan. Lingkaran itu lebih kecil dari kesenian rakyat, lebih khusus, lebih intens, lebih detail dan cenderung lebih perfeksionis. Pada waktu kerajaan-kerajaan sudah hilang, tradisi kesenian elite ini diteruskan oleh kaum pelajar dan kelas menengah atas yang menghuni kota (Kayam, 1981:140-141).

Kesenian rakyat dibeberapa lingkungan Indonesia tercipta secara anonim, menjangkau satu wilayah yang terbatas, tidak banyak mengalami perkembangan 
dan benar-benar merupakan refleksi dari satu kebudaaan petani. Dia adalah bentuk seni fungsional atau seni utilitas terhadap masyarakatnya. Baik tema, pengungkapannya lewat gerak maupun saat menampilkannya, tidak terpisah dari kepentingan menyeluruh dari sang kosmos (aturan) tersebut. Maka Kayam (1981:90) menyebutkan tarian-tarian itu menyangkut segala hal ikhwal yang berkaitan dengan kehidupan masyarakat petani. Dia akan menyangkut sang petani, sang padi dan sang badan halus yang menjaga padi dan petani.

Berdasarkan kesenian tradisional klasik dan rakyat merupakan kesenian yang tumbuh dikalangan masyarakat, sedangkan tradisional klasik hidup dimasyarakat keraton. Kesenian tradisional rakyat adalah kesenian yang berada dikalangan masyarakat menengah. Keduanya mendapatkan dukungan dari masyarakat dan dukungan dari istana dengan perlindungan kekuasaan raja.

\subsubsection{Tayub}

Tayub mempunyai pengertian tari atau menari, menurut tradisi lisan kata Tayub merupakan paduan dari kata Tata dan Guyub atau ditata ben guyub yang artinya tari diatur secara baik agar terwujud kerukunan. Kesenian Tayub (Tayuban) hidup di Jawa sebagai tari rakyat yang tumbuh dan berkembang dengan subur di Desa-Desa. Tayub mengandung pengertian sebagai tarian sewaktu berpasangan (Dokumentasi Pendidikan Daerah, 1986:87).

Tayub adalah salah satu bentuk seni pertunjukan tradisional yang tumbuh dan berkembang dengan subur. Tayub adalah sebuah tarian pergaulan yang banyak diminati oleh masyarakat, baik didesa maupun kota (Rohana, 2007:2). Tayub menghadirkan ledhek yang menari dan menyanyi nyinden (Rochana 
2007:2). Tayub yaitu tarian yang dilakukan oleh ledhek dan pengibing dengan iringan gamelan dan tembang. Biasanya untuk meramaikan pesta perkawinan dan sebagainya (Anton Dalam Rubini 2010:220). Pengertian Tayub seni pertunjukan yang menggunakan minuman keras. (warsito dalam Rabimin 2010:220).

Tayub merupakan bentuk pertunjukkan tari rakyat di Jawa yang disajikan oleh penari perempuan (ledhek atau joged) diiringi dengan seperangkat gamelan berlaras selendro atau pelog disertai tembang, serta dipertunjukkan ditempat tertentu (panggung, pendapa atau halaman). Pertunjukkan Tayub dilibatkan penonton terutama laki-laki untuk berpartisipasi langsung menjadi pasangan penari Tayub (joged) dalam menari diatas panggung. Oleh karena bentuk tari berpasangan itu Tayub mempunyai sifat erotis yang diwarnai dengan sensualitas dan seksualitas. Hal itu sebagai wujud dari simbol kesuburan (Suharto, 1999:12).

Pemeran utama dari Tayub adalah seorang penari perempuan dengan rias cantik, penari Tayub disebut ledhek, biasanya ledhek merupakan penari bayaran. ledhek dalam menari dan menyanyi senantiasa melibatkan para penontonnya untuk diajak menari bersama. Tari yang sering diadakan setelah panen ini banyak terdapat di daerah pulau Jawa dan pertunjukan ini disebut dengan istilah lain dari Tayub yakni Tayuban (Jazuli 2008:48).

Tayub atau Tayuban mempunyai banyak penafsiran yang saling memperluas, memperdalam dan memperjelas pengertiannya. Tayub dalam Kamus Bau Sastra Jawa-Indonesia, karangan Prawioratmojo (1981:243) berarti senangsenang dengan mengibing bersama tandak. Bisa juga menari bersama ledhek, joged atau ronggeng. 
Apabila merujuk pada pendapat Soeharto $(1999,12)$ dapat dikatakan ada dua pendapat mengenai kata Nayub, yaitu: (1.) Nayub berarti menari-nari dan (2.) Nayub berarti menari-nari yang ada kaitannya dengan minuman keras. Masyarakat sekarang ini tidak membedakan arti kata Nayub dan Tayub itu. Kata Tayub menjadi nama sebuah tarian tertentu (kata benda), sedangkan kata Nayub diberi pengertian sedang menari Tayub (kata kerja).

Paparan di atas dapat disimpulkan bahwa Tayub merupakan tari berpasangan dimana penari perempuan atau ledhek menari dengan pengibing diringi seperangkat gamelan. Serta minuman keras yang sudah menjadi ciri khas adanya kesenian Tayub yang disuguhkan untuk calon pengibing yang akan menari bersama ledhek Rohana (dalam tesis 2009:341).

\subsubsection{Bentuk Pertunjukan}

Kata bentuk mempunyai arti wujud yang ditampilkan. Menurut (Langer dalam Indriyanto, 2001:2) pengertian bentuk secara abstrak adalah struktur. Struktur adalah seperangkat tata hubungan di dalam bentuk membentuk satuan keseluruhan (Brown dalam Indriyanto, 2001:11). Jadi berbicara tentang bentuk pertunjukan berarti berbicara tentang bagian pembentuk pertunjukan. Pertunjukan secara garis besar digolongkan menjadi dua, yaitu: 1) perilaku manusia atau disebut juga pertunjukan, 2) pertunjukan budaya yang meliputi pertunjukan seni, olah raga, ritual, festival-fastival dan berbagai bentuk keramaian. Pertunjukan kedua yang penting bukanlah bentuk ungkapan artistiknya, melainkan tujuannya sangat diperlukan oleh masyarakat (Soedarsono, 2002:105). 
Bentuk pertunjukkan Tayub terdiri dari berbagai elemen yang saling terkait dan saling mendukung nilai estetik. Elemen-elemen itu adalah pemain, rias, busana, iringan, tempat pentas, dan waktu pertunjukkan, dan juga penikmat. Itulah yang dimaksud oleh Marinis (1993:8) bahkan sebuah pertujukkan merupakan Multilayered Entity. Hal itu dipertegas Soedarsono, bahwa pengkonseptualisasian pertunjukkan (teater) sebagai sebuah fenomena yang otonom serta merupakan entitas yang multilapis. Sebuah pertunjukkan merupakan perpaduan antara berbagai aspek penting yang menunjang seperti pemain, busana, iringan, tempat pentas, bahkan juga penonton (Soedarsono, 2001:5).

\subsubsection{Pemain Atau Pelaku}

Semua jenis seni pertunjukan memerlukan pelaku dalam penyajian, artinya seniman yang terlibat langsung atau tidak langsung dalam mengetengahkan atau menyajikan bentuk seni pertunjukan tersebut. Bentuk penyajian tari tertentu ada yang melibatkan pelaku laki-laki dan pelaku perempuan. Demikian pula halnya dengan usia atau umur pelaku seni pertunjukan juga bervariasi, yaitu pelaku anakanak, remaja, dewasa sampai orang tua. Mengenai jumlah pelaku juga bervariasi, yaitu pelaku tunggal, berpasangan dan kelompok (Cahyono, 2002:79). Sementara itu, teori menurut Suharto (1980:48) bahwa ledhek diartikan ngledhek untuk memikat hati, dimaksudkan agar semua penontonnya lebih-lebih para tamu dapat ngibing bersama ledhek.

Pelaku yang lain adalah pengrawit yang akan menabuh gamelan dalam pementasan Tayub, Pranatacara yang bertugas sebagai pemandu agar tercipta 
acara dengan suasana yang konduktif, pengarih dan yang terpenting adalah tamu undangan atau pengibing yang akan menari bersama ledhek.

\subsubsection{Tata Busana}

Tata busana tari sering muncul mencerminkan identitas (ciri khas) suatu daerah yang menunjukkan pada tari itu berasal, demikian pula pemakaian warna busana. Semua itu terlepas dari latar belakang budaya atau pandangan filosofi dari masing-masing daerah (Jazuli, 2008:20). Menurut Lestari (1993:3) busana memiliki beraneka ragam corak yang masing-masing memiliki ciri yang berbeda. Keanekaragaman busana ditentukan oleh cara pemakaian, bahan yang digunakan aksesoris sebagai pelengkapnya.

Unsur pendukung dalam tari Jazuli (2008:20) mengemukakan bahwa busana bersifat melengkapi sebuah seni pertunjukan. Penataan busana yang dapat mendukung penyajian tari akan menambah daya tarik penonton. Fungsi busana tari adalah untuk mendukung tema atau isi tari dan untuk memperjelas perananperanan dalam suatu sajian tari. Busana tari yang baik bukan hanya sekedar untuk menutupi tubuh semata, melainkan juga harus dapat mendukung design ruang pada saat penari sedang menari.

Tata busana merupakan unsur yang tidak dapat dipisahkan dan ditinggalkan dalam sebuah penyajian tari. Dalam penyajian Tayub busana yang digunakan menunjukkan karakteristik atau menambah keserasian penari Tayub atau joged, serta menunjukkan ketertarikan kepada masyarakat (Jazuli, 2008:20).

Busana dalam pertunjukan Tayub sampur (selendang) bagi ledhek dan pengibing yang digunakan untuk menari bersama sebagai wujud ekspresi penari. 
Selain itu sampur juga dimaknai sebagai simbol penghormatan kepada seseorang yang akan menari bersama ledhek yang disebut Tayuban (Hidajat, 2005:50).

Dapat disimpulkan bahwa, busana dan sampur merupakan pelengkap yang sangat penting dalam pertunjukan Tayub. Busana yang telah divariasi dapat menambah keserasian dalam kostum ledhek, sedangkan sampur sebagai properti yang terpenting dalam kelangsungan Tayuban.

\subsubsection{Tata Rias}

Rias terkait dengan cara berdandan untuk menghasilkan bentuk yang diharapkkan, dalam hal ini rias sebagai salah satu cara untuk mempercantik diri. Joged biasanya menggunakan bentuk rias korektif makeup (Richard, 1981:75). Rias merupakan hal yang paling peka dihadapan penonton, karena penonton biasanya sebelum menikmati tarian selalu memperhatikan wajah penari, baik untuk mengetahui tokoh atau peran yang sedang dibawakan maupun untuk mengetahui penarinya. Jazuli (2008:23) mengungkapkan fungsi rias antara lain untuk mengubah karakter pribadi menjadi karakter tokoh yang sedang dibawakan, untuk memperkuat ekspresi, dan untuk menambah daya tarik penampilan.

Rias yang digunakan dalam pertunjukan Tayub adalah rias cantik atau korektif yang digunakan joged untuk mempertegas garis-garis pada wajah yang berfungsi sebagai penguat ekspresi dan juga sebagai daya tarik para penonton.

\subsubsection{Iringan}

Iringan atau musik dalam tari bukan hanya sekedar sebagai pelengkap saja, tetapi juga sebagai pengiring tari yang sangat terkait, yang dapat memberikan suasana yang diinginkan dan mendukung alur cerita. Jazuli (2008:13) 
mengemukakan musik dan tari merupakan pasangan yang tidak dapat dipisahkan satu dengan yang lainnya. Keduanya berasal dari sumber yang sama, yaitu dorongan atau naluri ritmis. Fungsi musik atau iringan dalam tari adalah (1) sebagai pengiring tari (2) sebagai ilustrasi tari.

Fungsi musik dalam tari adalah sebagai aspek untuk mempertegas maksud gerak, membentuk suasana tari dan memberi rangsangan estetis pada penari dengan ekspresi jiwa sesuai dengan maksud karya tari yang ditampilkan (Indrianto, 2010:20).

Iringan yang digunakan sebagai pengiring dalam pertunjukan Tayub menggunakan laras pelog dan slendro, yang dalam penggunaannya ditabuh bergantian. Salah satu alat yang berperan penting dalam seperangkat gamelan yaitu kendhang, karena ekspresi penari sangat didukung oleh gamelan terutama kendhang. Iringan dalam pertunjukan Tayub sebagai pendukung terpenting, karena tanpa adanya musik pengiring pertunjukan Tayub tidak akan berjalan lancar. Musik pengiring dalam pertunjukan Tayub sebagai pengatur irama yang menambah semarak pertunjukan Tayub dan memberi suasana keindahan dalam setiap gerak penari Tayub.

\subsubsection{Tempat Penyajian}

Suatu pertunjukan apapun bentuknya selalu memerlukan tempat atau ruangan untuk menyelenggarakan pertunjukan itu sendiri. Indonesia mengenal bentuk-bentuk pertunjukan (pentas) seperti di lapangan terbuka atau di pendapa dan pemanggungan atau staging (Jazuli 1994:20). Tempat pertunjukan adalah lokasi atau arena yang akan dipergunakan dalam suatu pertunjukan. 
Paparan di atas dapat disimpulkan bahwa tempat penyajian sangat penting untuk kelancaran suatu pertunjukan, karena suatu pertunjukan tidak akan terlihat menarik jika dipentaskan ditempat selain panggung, pendapa atau lapangan terbuka. Tempat penyajian dalam pertunjukan Tayub dapat dipentaskan di atas panggung agar penonton lebih leluasa untuk menyaksikan dan menikmati pertunjukan Tayub.

\subsubsection{Pengibing}

Pengibing adalah seorang atau salah satu tamu undangan yang mendapat kesempatan menari Tayub di atas panggung bersama ledhek atau joged. Pengibing pada umumnya laki-laki, tetapi dalam perkembangan sekarang ini sering terlihat ada pula perempuan yang tampil sebagai pengibing (Rochana, 2007:222).

Kesenian Tayub terkenal sebagai tari berpasangan, paparan di atas menyebutkan pengibing adalah seseorang yang menjadi pasangan dalam pertunjukan Tayub yang menari bersama ledhek, maka dari itu pengibing adalah salah satu pelengkap tari berpasangan dalam pertunjukan Tayub.

\subsubsection{Penonton}

Seni pertunjukan tradisional kedudukan penonton sangat menentukan berhasil atau tidaknya sebuah pertunjukan. Penonton adalah salah satu komponen yang menentukan, oleh karena itu penonton harus diperhitungkan dalam perencanan penyajian suatu pertunjukan. Penonton pada pertunjukan Tayub, tidak terbatas pada usia-usia tertentu. Pengelompokan jenis usia menurut Soeparwoto (dalam Hurlock, 2007:55-56), dalam kehidupan bermasyarakat terdapat berbagai tingkatan usia yaitu : Masa Bayi (akhir minggu kedua-akhir tahun kedua), usia 
awal masa anak-anak (2-6 tahun), usia akhir masa anak-anak (6-12 tahun), masa puber atau pra remaja (12-14 tahun), masa remaja (14-18 tahun), usia dewasa (1840 tahun), masa dewasa madya (40-60 tahun), serta masa dewasa lanjut (60meninggal) dan penonton yang menonton pertunjukan Tayub di Desa Bedingin mencakup seluruh kelompok usia.

Pertunjukan dalam Tayub akan terjadi interaksi sosial antara joged dan penonton, interaksi sosial menurut Wadiyo (2008:59) adalah suatu hubungan sosial manusia, baik individu-individu dan kelompok atau individu dengan kelompok ditujukan adanya suatu ciri telah terjadi suatu aksi dan redaksi diantara mereka yang berhubungan. Interaksi sosial tersebut digambarkan dalam bentuk kesinambungan masyarakat setempat dengan mendengar suatu seni pertunjukan.

\subsubsection{Tamu Undangan}

Fiqih dalam Abujola (2010:5) kata $d a^{\prime} a$ adalah bentuk kata kerja yaitu da'awuh yang berarti ajakan. Maka dipahami dari pengertian kata ini adanya tiga komponen yaitu: (1) pihak yang mengajak (2) pihak yang diajak (3) jenis ajakan. Berkenaan dengan masalah ini ada beberapa bahasan yang perlu untuk diketahui yaitu: (1) mengundang secara langsung (menyebutkan namanya). (2) mengundang orang-orang baik dan saleh. (3) tidak boros dan tidak juga bakil dalam acara. (4) tidak mendesak seorang yang tengah berpuasa untuk membatalkan puasanya. (5) bersikap ramah terhadap seluruh undangan.

Mengadakan acara (pesta) pernikahan adalah yang disyari'atkan bahkan sebagian ulama menyatakan wajib, pengadaan acara (pesta) nikah adalah hal yang mesti bagi pasangan yang telah menikah dan momen-momen yang lain seperti 
Khitanan, Aqiqahan, dan seterusnya. Hukum menjawab undangan pernikahan adalah wajib, baik undangan pernikahan atau undangan selainnya. Apabila salah seorang dari kalian diundang untuk menghadiri pesta, maka hendaklah ia mendatanginya (H.R Muslim, 2014:4).

Paparan di atas dapat disimpulkan bahwa tamu undangan wajib untuk menghadiri acara apapun termasuk dalam pertunjukan kesenian Tayub. Kehadiran tamu undangan dan penonton adalah salah satu faktor pendukung jalanya suatu pertunjukan sebagai pemeriah acara. Pertunjukan tidak akan berjalan lancar tanpa adanya masyarakat yang berperan sebagai tamu undangan maupun penonton.

\subsubsection{Pedagang}

Pedagang yang didalam usahanya menggunakan sarana atau perlengkapan yang mudah dibongkar pasang atau dipindahkan dan mempergunakan tempat usaha, menempati tanah yang dikuasai pemerintah daerah atau pihak lain (Perda Kota Semarang Nomor 11 Tahun 2000)

Pedagang juga diartikan sebagai orang yang bermodal relatif sedikit berusaha dibidang produksi dan berjualan barang-barang (jasa-jasa) untuk memenuhi kebutuhan kelompok konsumen tertentu didalam masyarakat. Aktivitasnya dilaksanakan pada tempat-tempat yang setrategis dalam suasana lingkungan yang informal (Akhirudin, 1982). Universitas Parahiyangan (dalam putra, 1993:27) mendefinisikan pedagang sebagai orang dengan modal relatif sedikit berusaha (produksi penjualanbarang atau jasa) untuk memenuhi kebutuhan kelompok konsumen tertentu didalam masyarakat, usaha mana dilakukan pada tempat-tempat yang dianggap strategis dalam suasana informasi. 
Pernyataan di atas dapat ditarik kesimpulan bahwa pedagang sebagai salah satu tempat untuk memenuhi suatu kebutuhan konsumen dalam masyarakat. Pedagang berjualan dengan menggunakan sarana perlengkapan yang mudah dibongkar pasang ditempat-tempat yang informal. Maka dari itu dalam suatu acara Tayuban terdapat pasar dadakan atau pasar tiban yang diperankan oleh masyarakat sebagai pedagang yang berjualan disekitar arena pertunjukan Tayub. 


\subsection{Kerangka Berfikir}

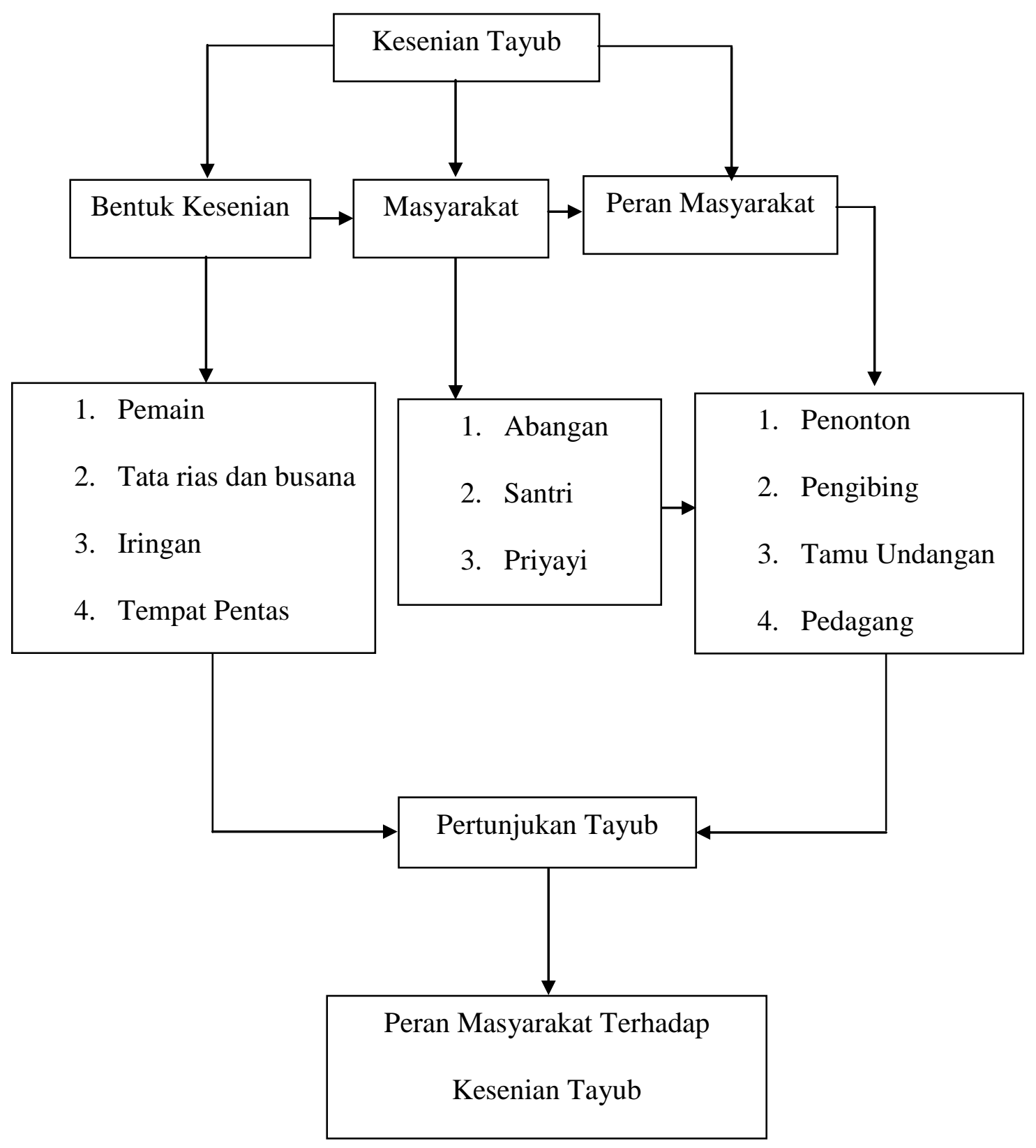

Bagan 2.1 Kerangka Berfikir 


\section{Keterangan Bagan :}

Berdasarkan landasan teoretis dan tinjauan pustaka, memberikan gambaran kerangka berfikir seperti bagan di atas, peneliti akan melakukan penelitian mengenai bentuk pertunjukan kesenian Tayub meliputi pembukaan, inti dan penutup yang terdiri dari pemain, iringan, tata rias busana dan tempat pentas. Masyarakat Bedingin merupakan masyarakat yang meliputi Abangan, Santri dan Priyayi, disinilah peneliti akan meneliti tentang Peran Masyarakat Terhadap Kesenian Tayub di Desa Bedingin Kecamatan Todanan Kabuaten Blora. Berdasarkan peran masyarakat terhadap kesenian Tayub yaitu sebagai penonton, pengibing, tamu undangan dan pedagang. 


\section{BAB III \\ METODE PENELITIAN}

\subsection{Pendekatan Penelitian}

Menurut Margono (2000:18), penelitian adalah penerapan pendekatan ilmiah pada pengkajian suatu masalah, metode penelitian adalah suatu cara yang digunakan untuk memecahkan masalah dan mendapatkan jawaban yang benar secara sistematik.

Pada penelitian ini peneliti menggunakan pendekatan yang berupa pendekatan kualitatif, yaitu prosedur yang menggunakan data yang berupa uraian kalimat tertulis ataupun lisan dari suatu objek yang bertujuan untuk menggunakan hal-hal yang berhubungan dengan keadaan suatu gejala (Rahman, 1993:108).

Penelitian kualitatif berakar pada latar alamiah sebagai keutuhan, mengandalkan manusia sebagai alat penelitian, memanfaatkan pada metode kualitatif, mengadakan menganalisis data secara induktif, mengarahkan sasaran penelitiannya pada usaha menemukan teori dasar, bersifat deskriptif, lebih mementingkan proses daripada hasil, membatasi studi dengan fokus, memiliki seperangkat kriteria untuk memeriksa keabsahan data, rancangan penelitiannya bersifat sementara dan hasil penelitiannya disepakati oleh kedua belah pihak yaitu peneliti dan subjek penelitiannya (Moleong, 2001:27).

Berdasarkan pokok permasalahan yang dikaji, maka penelitian ini menggunakan metode penelitian kualitatif yang menghasilkan data-data deskriptif berupa kata-kata tertulis atau lisan yang lebih menekankan makna 
dengan menggeneralisasikan permasalahan secara mendalam. Alasan yang mendasari digunakannya pendekatan kualitatif yaitu 1) Peneliti dapat mengupas permasalahan secara mendalam karena sifatnya tentatif dan berkembang setelah peneliti berada di lapangan. 2) Peneliti mampu melihat fenomena secara lebih luas dan mendalam sesuai dengan yang terjadi dan berkembang situasi sosial yang diteliti. 3) Peneliti dapat menentukan situasi sosial secara keseluruhan berdasarkan aspek tempat (place), pelaku (aktor), dan aktivitas (activity) yang berinteraksi secara sinergis (Pramudyani, 2011: 58).

Pada penelitian ini juga menggunakan pendekatan sosiologi, yaitu pendekatan yang memperhatikan lingkungan dalam masyarakat, yang melibatkan pendekatan individu dan interaksi. Pendekatan individu meliputi watak kemampuan psikomotorik yang mengerti tata kehidupan masyarakat. Pendekatan interaksi pendekatan interaksional individu dan sosial mempengaruhi hubungan timbal balik antar individu dan masyarakat. (Ahmadi, 1991: 44-45).

Paparan di atas menggunakan pendekatan kualitatif dan pendekatan sosiologi. Pendekatan ini dimaksudkan untuk mendeskripsikan tentang bentuk pertunjukan dan peran masyarakat terhadap kesenian Tayub di Desa Bedingin Kecamatan Todanan Kabupaten Blora.

\subsection{Lokasi dan Sasaran Penelitian}

\subsubsection{Lokasi Penelitian}

Lokasi penelitian dilakukan di Desa Bedingin Kecamatan Todanan Kabupaten Blora Jawa Tengah. Penelitian pertama dalam penelitian ini mengambil lokasi dirumah Purwaningsih selaku penari Tayub Desa Bedingin 
RT/RW 006/002. Penelitian kedua dirumah Bapak Sakiman RT/RW 008/002 selaku tuan rumah hajatan, serta bertepatan dengan berkumpulnya masyarakat yang menyaksikan pertunjukan Tayub.

Alasan peneliti mengambil penelitian dilokasi tersebut agar mempermudah peneliti untuk melakukan penelitian, karena bertepatan dengan adanya pertunjukan Tayub serta terdapat kumpulan masyarakat yang datang sesuai dengan perannya masing-masing.

\subsubsection{Sasaran Penelitian}

Sasaran dalam penelitian ini adalah mengenai bentuk pertunjukan dan Peran Masyarakat Terhadap Kesenian Tayub di Desa Bedingin Kecamatan Todanan Kabupaten Blora.

\subsection{Teknik Pengumpulan Data}

Pengumpulan data dalam penelitian ini dimaksudkan agar memperoleh datayang akurat. Data menggunakan teknik observasi, wawancara, dokumentasi dan analisis data. Pengumpulan data dengan teknik dan alat pengumpulan data yang tepat memungkinkan data yang obyektif (Arikunto, 1982:142). Pengumpulan data yang digunakan dalam penelitian ini yaitu observasi, wawancara dan dokumentasi.

\subsubsection{Observasi}

Menurut Arikunto (1998:146) memberikan pengertian observasi adalah pengamatan yang meliputi perbuatan pemantauan terhadap suatu objek yang menggunakan seluruh indera atau pengamatan langsung. Observasi dalam 
penelitian ini menggunakan cara langsung terhadap observasi yang relevan dengan kondisi lingkungan dilokasi penelitian yang diamati.

Teknik observasi digunakan dalam penelitian ini dengan maksud untuk mendapatkan informasi dan data secara langsung dari lokasi penelitian, yaitu untuk melihat secara langsung bagaimana bentuk pertunjukan dan peran masyarakat terhadap kesenian Tayub di Desa Bedingin Kecamatan Todanan Kabupaten Blora.

\subsubsection{Wawancara}

Wawancara adalah percakapan yang dilakukan antara dua pihak yaitu pewawancara yang mengajukan pertanyaan dengan yang diwawancarai memberi jawaban atas pertanyaan itu. Wawancara mencakup cara yang digunakan untuk mendapat keterangan lisan dari responden dengan bercakap-cakap dan tatap muka (Moleong 2002:135).

Wawancara dibagi menjadi dua, yaitu pertama wawancara tertutup. Pertanyaan yang diajukan difokuskan pada topik-topik khusus. Panduan wawancara dibuat rinci. Kedua wawancara yang terbuka, peneliti memberikan kebebasan diri dan mendorongnya untuk berbicara secara luas dan mendalam. Subjek penelitian lebih kuat pengaruhnya dalam menentukan isi wawancara (Danim, 2002: 132). Peneliti melakukan wawancara tertutup dan terbuka terhadap responden.

Selain itu juga pewawancara membawa pedoman atau daftar pertanyaan tentang hal yang akan diteliti. Langkah-langkah yang dilakukan dalam wawancara meliputi menentukan lokasi, menentukan informan yang akan dijadikan sumber 
informasi, menentukan waktu wawancara, membuat daftar pertanyaan yang akan diajukan kepada responden. Wawancara yang akan dilakukan dalam penelitian ini meliputi bentuk pertunjukan dan peran masyarakat.

Wawancara dilaksanakan dengan cara mengunjungi ke tempat sumber informasi, baik dipertunjukan, kantor, maupun dirumah. Wawancara diusahakan dapat berlangsung secara wajar dan tidak resmi, sehingga tidak menimbulkan suasana pembicaraan yang kaku. Wawancara difokuskan untuk menggali informasi tenteng pertunjukan Tayub. Tokoh masyarakat (pengarih), Dinas Pariwisata, Perangkat Desa, joged, pengibing, pengiring (pengrawit) dan masyarakat atau penonton. Untuk mempermudah wawancara peneliti menggunakan alat bantu Handphone (recorder) Wawancara ditujukan pada informasi untuk menggali informasi, wawancara tersebut dilakukan kepada (1) tokoh masyarakat (sekaligus sebagai pengarih) dengan maksud menggali informasi tentang asal usul kesenian Tayub, faktor yang mempengaruhi terjadinya perkelahian, urutan pertunjukan Tayub; (2) Joged dan pengibing untuk menggali informasi tentangpara pemain, kostum dan tata rias; (3) pemain musik untuk menggali informasi tentang musik-musik apa yang diamainkan dalam pertunjukan Tayub; (4) masyarakat atau penonton untuk menggali informasi mengenai tangapan masyarakat terhadap pertunjukan Tayub serta dampak positif dan negatif terhadap pertunjukan Tayub yaitu, (5) pedagang yang selalu mengikuti adanya pertunjukan Tayub untuk menggali informasi tentang dampak yang ada dalam menjual dagangannya ditengah-tengah penonton. 
Pada tahap wawancara peneliti mengadakan wawancara dengan para pendukung pertunjukan Tayub yang dapat diuraikan sebagai berikut:

3.3.2.1 Wawancara dilakukan peneliti pada tanggal 5 September 2015, yang kemudian dilakukan pada tanggal 14 September 2015 hingga 24 November 2015, adapun pihak yang diwawancarai adalah tokoh masyarakat (sekaligus sebagai pengarih), mendapatkan data informasi tentang bagaimana kesenian Tayub, bagaimana sejarah Tayub, bagaimana perkembangan Tayub, bagaimana kedudukan pengarih dalam pertunjukan Tayub, adakah sesaji khusus dalam pertunjukan Tayub, pada saat akan pentas apakah ada syarat-syarat khusus yang dijalankan oleh pengrih supaya pementasan atau pertunjukan berhasil, apakah nama penari lakilaki dalam pertunjukan Tayub, apakah peran pengibing dalam pertunjukan Tayub, apakah dalam pertunjukan Tayub para pengibing dapat ditarikan oleh laki-laki dan perempuan serta anak-anak, faktor apa yang mempengaruhi pengibing terjadi konflik, ditampilkan dalam acara apa saja kesenian Tayub, bagaimana bentuk gerak pengibing dalam kesenian Tayub. Wawancara kepada pemusik yaitu tentang apa saja alat musik yang digunakan dan menggunakan lagu apa saja dalam mengiringi pertunjukan Tayub.

3.3.2.2 Wawancara dengan perangkat desa, menanyakan tentang letak dan kondisi Geografis lokasi penelitian, kependudukan masyarakat, struktur penduduk menurut mata pencaharian masyarakat, agama dan penidikan masyarakat lokasi penelitian. Wawancara dilakukan di Rumah Bapak Kepala Desa 
Bedingin Kecamatan Todanan dan meminta dokumen-dokumen seperti petadan denah lokasi penelitian sebagai lampiran dalam skripsi.

3.3.2.3 Wawancara dengan Ibu Purwaningsih (41 Tahun) salah satu joged atau ledhek yang ditanyakan antara lain sudah berapa lama berprofesi sebagai joged, apakah anda mempunyai bakat nyindendan menari sebelumnya, apakah ada syarat menjadi joged, apakah profesi joged dapat membantu perekonomian keluarga, berapa banyak penghasilan disetiap pentas, apakah yang menjadi kendala ketika dalam pertunjukan Tayub, bagaimana menanggapi pandangan negatif dari masyarakat, wawancara kepada masyarakat atau penonton mengenai tanggapan terhadap kesenian Tayub.

3.3.2.4 Wawancara dengan Bapak Agil sebagai ketua pengrawit mendapatkan data lengkap tentang iringan, laras, dan gamelan yang akan digunakan dalam pertunjukaan Tayub.

3.3.2.5 Wawancara dengan masyarakat Desa Bedingin yaitu mendapatkan data tentang peran-peran dan minat masyarakat terhadap pertunjukan Tayub. Wawancara yang telah dilakukan oleh peneliti menghasilkan gambaran tentang lokasi penelitian yaitu Desa Bedingin Kecamatan Todanan Kabupaten Blora, gambaran kesenian Tayub, sejarah kesenian Tayub, peran dan tanggapan masyarakat terhadap pertunjukan Tayub.

\subsubsection{Dokumentasi}

Dokumentasi menurut (Sugiyono, 2009:329) adalah catatan peristiwa yang sudah berlaku, sedangkan dokumentasi menurut Esterberg (dalam Sarosa, 
2012:61) adalah segala sesuatu materi dalam bentuk tertulis yang dibuat oleh manusia. Dokumen yang dimaksud adalah segala catatan baik berbentuk catatan kertas (hardcopy) maupun elektronik (softcopy). Dokumen dapat berupa buku, catatan harian, sejarah hidup, artikel media masa, manifesto, undang-undang, notulen, blog, halaman web, foto dan lain-lain. Teknik pengumpulan data dengan dokumentasi digunakan untuk menggali informasi tentang pertunjukan seni tradisional Tayub melalui arsip tersedia.

Data dokumentasi yang menjadi perhatian adalah pertunjukan Tayub dan managemen pengelolaan kesenian Tayub. Data-data yang dikumpulkan melalui teknik pengumpulan data dokumentasi dalam penelitian ini adalah tempat yang menjadi lokasi penelitian, peneliti menggunakan alat bantu kamera untuk mengambil foto dan video dalam pertunjukan Tayub yang peneliti lakuakan.

\subsection{Teknik Analisis Data}

Analisis data dapat dibedakan menjadi dua macam yaitu, kualitatif dan kuantitatif. Perbedaan ini tergantung dari sifat data yang dikumpulkan. Data yang bersifat monografis disebut analisis kuantitatif statistik, sedangkan yang berdasarkan pada data yang terkumpul disebut analisis kualitatif. Proses pengumpulan data dan menyeleksi data yang diperoleh, selanjutnya menyederhanakan data dengan cara mengurangi dan membuang yang tidak perlu, kemudian mengelompokkan secara terpisah sesuai dengan sub pokok bahasan. Sebelum menganalisis data, semua data yang diperoleh dari teknik observasi, wawancara dan dokumentasi dikelompokkan terlebih dahulu. Data tersebut digabungkan dan dikumpulkan untuk menjelaskan sasaran yang diteliti. 
Proses analisis data dalam penelitian kualitatif dimulai dengan menelaah seluruh data yang tersedia dari berbagai sumber, yaitu wawancara dan pengamatan yang sudah tertulis dalam catatan lapangan, dokumentasi pribadi, dokumentasi resmi, gambar, foto, dan sebagainya. Data tersebut sangat banyak, oleh sebab itu peneliti harus membaca dan mempelajarinya (Sumaryanto, 2007:105).

\subsection{Teknik Keabsahan Data}

Langkah terakhir dari analisis data dalam penelitian ini adalah verifikasi atau pemeriksaan keabsahan data. Pemeriksaan keabsahan data dalam penelitian ini memakai dependabilitas dan konfirmabilitas (Lincoln dan Guba dalam Jazuli, 2011 : 34). Data yang didapat dari hasil observasi, wawancara dan dokumentasi selanjutnya ditafsirkan hingga penarikan kesimpulan, dan melakukan pengecekan serta pengkajian silang dengan pakar atau teman sejawat. Disamping itu, juga menggunakan member cheking, yakni meminta pengecekan dari informan, pemain dan penonton. 


\section{BAB IV}

\section{HASIL PENELITIAN DAN PEMBAHASAN}

\subsection{Gambaran Umum Lokasi Penelitian}

\subsubsection{Lokasi dan Kondisi Geografis Desa Bedingin}

Lokasi penelitian tentang Peran Masyarakat Terhadap Kesenian Tayub di Desa Bedingin Kecamatan Todanan Kabupaten Blora.Desa ini merupakan salah satu desa terluas dari 25 desa yang berada di Kecamatan Todanan.Desa Bedingin memiliki 24 RT dan 3 RT mempunyai batasan-batasan desa yaitu, sebelah utara Desa Ledok, sebelah barat Desa Candi, sebelah selatan Desa Kembang, sebelah timur Desa Gaplokan

Secara geografis Desa Bedingin terletak jauh dari keramaian kota dan berada ditengah-tengah hamparan hutan dan sawah sekitar $10 \mathrm{~km}$ dari pusat kecamatan dan $40 \mathrm{~km}$ dari pusat Ibu Kota Kabupaten Blora. Luas wilayah Desa Bedingin 7.125,4 Ha, sebagian besar wilayahnya hutan dan sawah.Desa Bedingin Kecamatan Todanan Kabupaten Blora memiliki jumlah penduduk 4.863 jiwa.

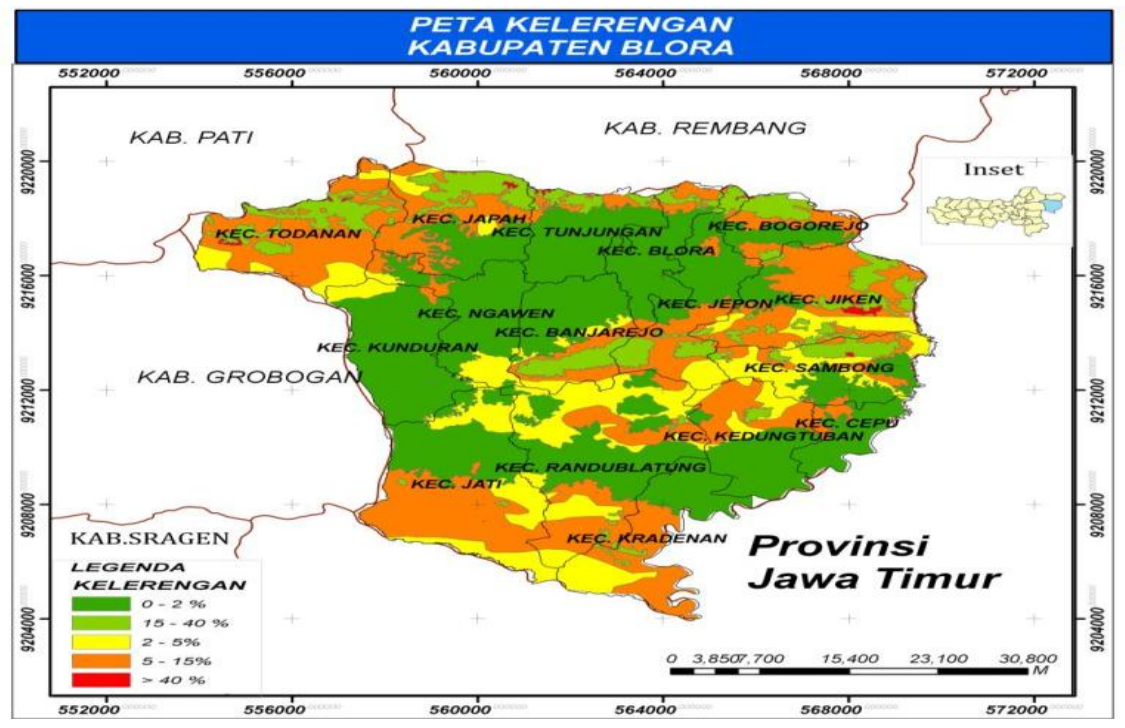

Peta Kabupaten Blora 
Jalur untuk sampai ke Desa Bedingin melewati jalur selatan yaitu Semarang, Demak, Purwodadi, Blora. Sebelum sampai Kota Blora terdapat pertigaan Desa Gagaan yang terletak diperbatasan Kota Blora dengan Purwodadi, mengambil arah kekiri untuk sampai ke Kecamatan Todanan, sesampai kapolsek Todanan terdapat perempatan belok kanan dari kapolsek mengambil arah Puncakwangi Pati sekitar 5 km dari kapolsek terdapat pertigaan Desa Sumurwatu ambil kanan untuk menempuh $10 \mathrm{~km}$ sampai ke Desa Bedingin, karena medan jalannya rusak dan naik turun gunung.

Warga Desa Bedingin mayoritas masyarakatnya beraktifitas setiap hari kesawah dengan menggunakan sepeda motor atau berjalan kaki. Masyarakat yang lebih memilih jalan kaki dianggap menyehatkan, karena termasuk berolahraga. Untuk masyarakat yang pekerjaannya diluar kawasan Desa Bedingin harus menggunakan kendaraan pribadi atau dengan menggunakan angkutan umum karena kawasan Desa Bedingin dengan pusat kota terlampau jauh. Wawancara dengan Perangkat Desa Bedingin (carik), Oktober 2015.

\subsubsection{Jumlah Penduduk}

Tabel 1 : Jumlah penduduk Desa Bedingin menurut umur dan jenis kelamin

\begin{tabular}{|l|l|l|l|l|}
\hline \multirow{2}{*}{ No. } & \multirow{2}{*}{ Golongan Usia } & \multicolumn{2}{|l|}{ Klarifikasi } & \multirow{2}{*}{ Jumlah } \\
\cline { 3 - 4 } & $0-15$ & Laki-Laki & Perempuan & \\
\hline 1. & & 738 Jiwa & 754 Jiwa & \\
\hline 3. & $16-55$ & 882 Jiwa & 890 Jiwa & \\
\hline 3. & 55 Keatas & 775 Jiwa & 769 Jiwa & \\
\hline \multicolumn{2}{|l|}{ Jumlah } & 2.395 Jiwa & 2.413 Jiwa & 4.808 Jiwa \\
\hline
\end{tabular}

(Sumber : Data Monografi Desa Bedingin 2015). 
Komposisi penduduk pada tabel 1 bisa dilihat bahwa sebagian besar masyarakat Desa Bedingin mempunyai persentase jumlah penduduk tertinggi pada kelompok usia 16-55 tahun, yaitu sebanyak 1.772 jiwa. Untuk persentase jumlah penduduk terendah pada kelompok usia 0-15 tahun, yaitu sebanyak 1.492 orang. Persentase jumlah penduduk apabila dikaitkan dengan minat masyarakat untuk berpartisipasi dalam pertunjukan Tayub di Desa Bedingin lebih banyak pada kelompok usia dewasa dan usia lanjut. Masyarakat dari lain desa juga ikut bergabung dalam pertunjukan Tayub yang diadakan di Desa Bedingin.

Penduduk Desa Bedingin pada umumnya memperoleh penghasilan dari pertanian, karena didukung kondisi tanah yang subur, irigasi yang memadai dan iklim yang cocok. Masyarakat Desa Bedingin berdasarkan monografi Desa Bedingin periode 2013 menunjukkan sebagian besar penduduknya bekerja sebagai petani. Masyarakat Desa Bedingin ada yang bekerja sebagai Pegawai Negeri Sipil, pedagang, wiraswasta, buruh pabrik, buruh bangunan, buruh tani dan jasa. Wawancara dengan Kepala Desa Bedingin ditempat.

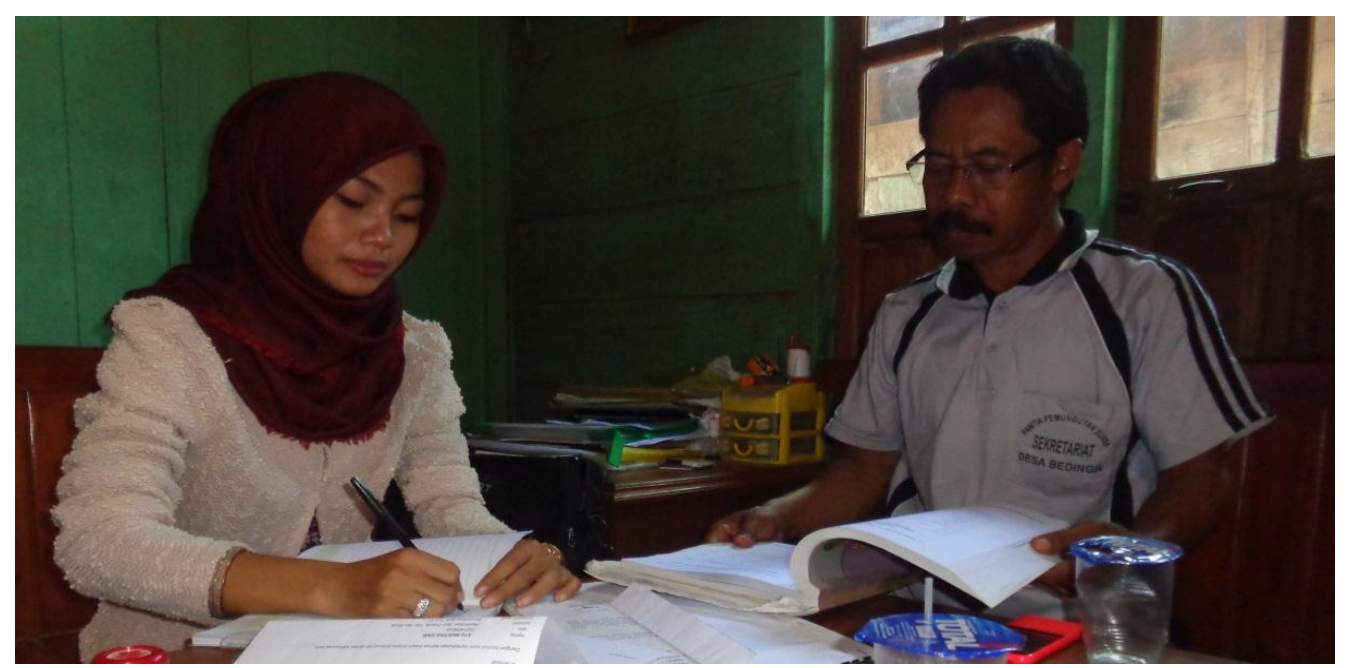

Foto 1: Wawancara Dengan Kepala Desa

(Dokumentasi: Ayu, November 2015) 
Kelompok tani tersebut ada yang mengerjakan sawah tanahnya sendiri, ada juga sebagian buruh tani yang mengerjakan sawah orang lain dengan sistem bagi hasil ataupun menyawa sawah. Masyarakat Desa Bedingin sebagian bekerja sebagai petani sawah maupun ladang yang menghasilkan sayur-sayuran, padi serta palawija. Adapun hasil dari pertanian dijual kepasar, kebeberapa daerah dan sebagian untuk kebutuhan sehari-hari. Adapun data mata pencaharian Desa Bedingin sebagai berikut.

\subsubsection{Mata Pencaharian}

Tabel 2 : Penduduk Desa Bedingin berdasarkan mata pencaharian

\begin{tabular}{|l|l|l|}
\hline No. & Jenis Pekerjaan & Jumlah \\
\hline 1. & Karyawan (PNS/TNI/POLRI) & 25 Jiwa \\
\hline 2. & Tani & 1.235 Jiwa \\
\hline 3. & Buruh Tani & 45 Jiwa \\
\hline 4. & Tukang & 51 Jiwa \\
\hline 5. & Batu & 65 Jiwa \\
\hline 6. & Penjahit & 5 Jiwa \\
\hline 7. & Pensiun & 7 Jiwa \\
\hline 8. & Perangkat & 8 Jiwa \\
\hline 9. & Pengrajin & 3 Jiwa \\
\hline 10. & Industri & 7 Jiwa \\
\hline 11. & Peternak & 1.415 Jiwa \\
\hline 12. & Pedagang & Lain-Lain \\
\hline 13. & & \\
\hline
\end{tabular}

(Sumber : Data Monografi Desa Bedingin Tahun 2015) 
Data yang diperoleh dari tabel 2 dapat dilihat dominanya pekerjaan sebagai petani. Pemerintah Desa Bedingin juga melakukan klarifikasi antara tani dan buruh tani. Bila dilihat secara sekilas nampak ada kesamaan, bahwa samasama sebagai petani, perbedaanya tani memiliki tanah atau sawah sendiri dan ada kalanya mengelola sendiri, sedangkan buruh tani adalah petani yang tidak memiliki tanah atau sawah sendiri dan mengelola sawah pemilik tanah (tani). Desa Bedingin merupakan desa yang berdiri dipegunungan diantara hutan dan hamparan ladang, masyarakat Bedingin memenuhi kebutuhan pokok dengan bertani industri kecil (pengrajin), sebagai buruh, karyawan, Pegawai Negeri Sipil (PNS), anggota Tentara Nasional Indonesia (TNI), Polisi dan beternak. Berikut jumlah penduduk berdasarkan pekerjaan dan mata pencaharian.

Tabel 3 : Jumlah penduduk menurut mata pencaharian.

\begin{tabular}{|l|l|l|}
\hline No. & Mata Pencaharian & Jumlah Penduduk \\
\hline 1. & Petani & 1.235 Jiwa \\
\hline 2. & Pengrajin & 3 Jiwa \\
\hline 3. & Buruh & 45 Jiwa \\
\hline 4. & Pedagang & 56 Jiwa \\
\hline 5. & PNS & 15 Jiwa \\
\hline 6. & Anggota TNI & 10 Jiwa \\
\hline 7. & Pensiun & 7 Jiwa \\
\hline 8. & Peternak (4 Kelompok) & \\
\hline & 1. Sapi & 657 Jiwa \\
\hline & 2. Kambing & 237 Jiwa \\
\hline & 3. Ayam & 353 Jiwa \\
\hline & 4. Bebek & 168 Jiwa \\
\hline
\end{tabular}

(Sumber data monografi Desa Bedingin Tahun 2015) 


\subsubsection{Pendidikan}

Kehidupan masyarakat Desa Bedingin sudah banyak dipengaruhi sistem pendidikan dan teknologi. Sistem pendidikan yang semakin berkembang telah menyadarkan pada pola pikir masyarakat bahwa betapa pentingnya arti pendidikan bagi anak-anak dengan demikian masyarakat Desa Bedingin tidak jauh berbeda dari masyarakat desa yang lebih maju. Secara lebih rinci berikut ini adalah tabel tingkat pendidikan penduduk Desa Bedingin.

Tabel 4 : Jumlah penduduk Desa Bedingin menurut pendidikan.

\begin{tabular}{|l|l|l|}
\hline No. & Tingkat & Jumlah \\
\hline 1. & Tamat SD & 3.808 Jiwa \\
\hline 2. & Tamat SMP & 394 Jiwa \\
\hline 3. & Tamat SMA/SMEA/STM & 200 Jiwa \\
\hline 4. & Tamat Perguruan Tinggi & 53 Jiwa \\
\hline 5. & Tidak Sekolah & 0 Jiwa \\
\hline
\end{tabular}

(Sumber : Data Monografi Desa Bedingin, Tahun 2015)

Tabel 4 di atas adalah data penduduk dengan status pendidikan yang berada di Desa Bedingin. Jumlah paling banyak tamatan SD yaitu dengan jumlah 3.808 jiwa, kemudian urutan kedua adalah tamatan SMP dan berikutnya SMA. Pendidikan yang tidak dapat melanjutkan ke jenjang lebih tinggi umumnya mengikuti kursus-kursus ketrampilan antara lain, perbengkelan, pertukangan, menjahit, komputer, dan bordir. Memiliki modal ketrampilan tersebut banyak penduduk yang membuka usaha pekerjaan sebagai wirausaha. 
Kondisi tersebut dapat dilihat dari pelaku kesenian Tayub yang produktif dalam kesenian dapat disimpulan bahwa jika dikaitkan dengan usia dan tingkat pendidikan rata-rata dari tamatan SD dan SMP usia remaja ikut serta mempelajari kebudayaan menjadi pengrawit atau menjadi ledhek, hal ini menunjukan bahwa masyarakat ikut berpartisipasi menjadi seniman selain bertani, karena dapat dikatakan sebagai pekerjaan sampingan. Berdasarkan hasil wawancara dengan Bapak Kacung Saputro (40 tahun) selaku wirosuworo pada Oktober 2015 menjelaskan sebagai berikut:

Menjadi seorang seniman itu menurut saya adalah hobi. Dimana ada rasa kesenangan tersendiri dalam jiwa saya, dibandingkan sekolah yang belum tentu nanti akan bekerja apa, mikir mengejar rumus, teori dan sebagainya. Pikiran saya tidak sampai kalau mikir sekolah mbak. Selain itu juga saya terjun menjadi seniman menghasilkan uang, kalausekolah membuang uang. Tapi kalau untuk anak saya nanti tergantung memilih sekolah lagi atau bekerja, saya memberi kebebasan.

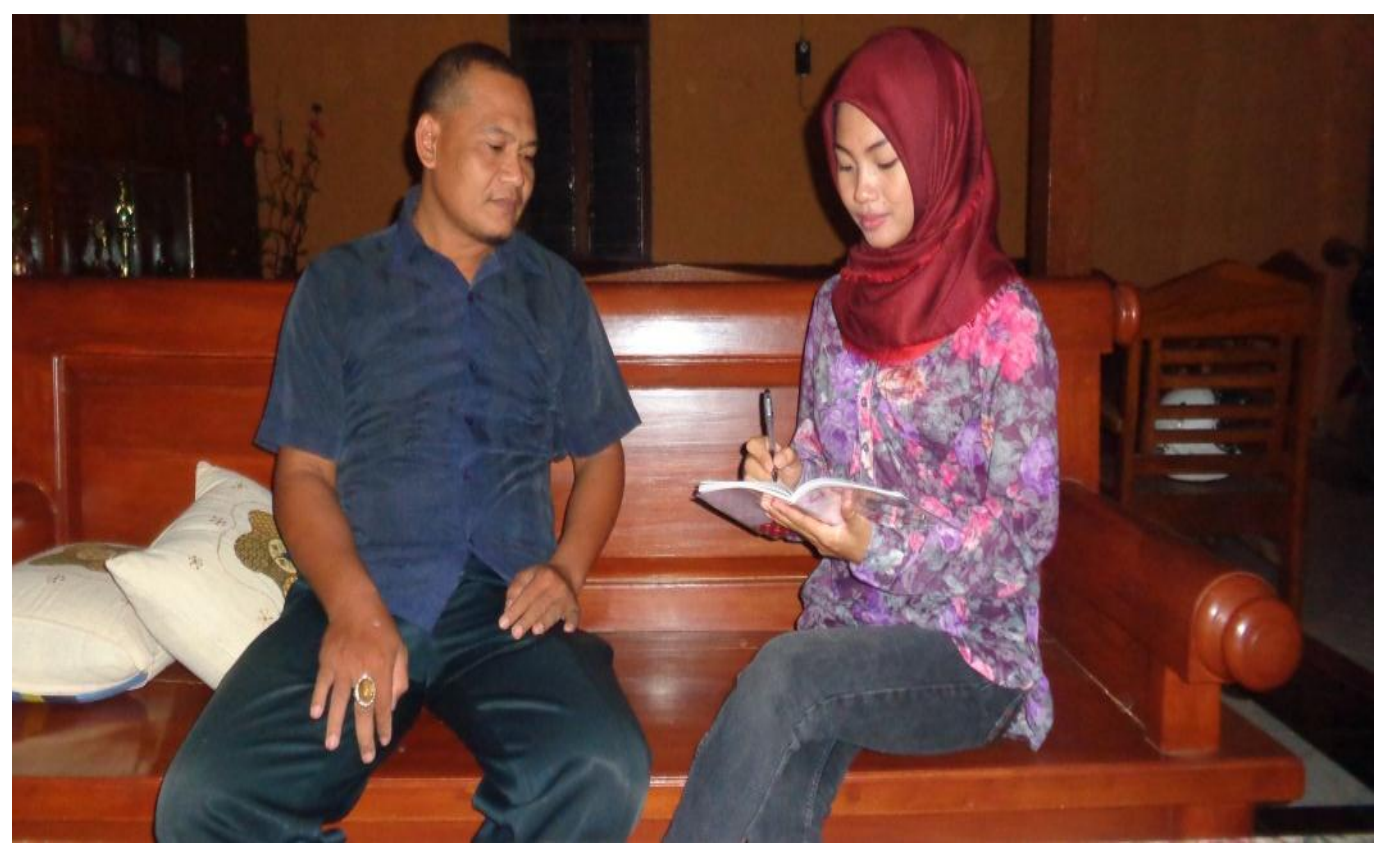

Foto 2: Wawancara Dengan Bapak Kacung (wirosuworo)

(Dokumentasi : Ayu, Oktober 2015) 
Wawancara dengan Ibu Purwaningsih (ledhek) pada Oktober 2015 dilokasi pertunjukukan Todanan

Menurut saya berkesenian itu dapat dipelajari diusia remaja, contohnya diusia belasan tahun. Soalnya belajar menjadi joged itu membutuhkan waktu yang sangat lama, ada yang sudah 15 tahun menjadi joged tapi masih belum bisa menyanyi Jawa, hanya menang di perawakan yang memadai. Belajar njoged kalau sudah menginjak usia 28 tahun ke atas sudah tidak laku lagi dipasaran atau sudah terlalu tua untuk belajar njoged. Saya belajar njoged waktu usia saya 14 tahun hingga saat ini, tapi anak-anak saya kalau bisa saya lebih tekankan lagi ke perguruan yang lebih tinggi selama saya masih mampu membiayai anak-anak saya, karena saya tidak mau anak-anak saya mengikuti langkah saya yang kurang berpendidikan.

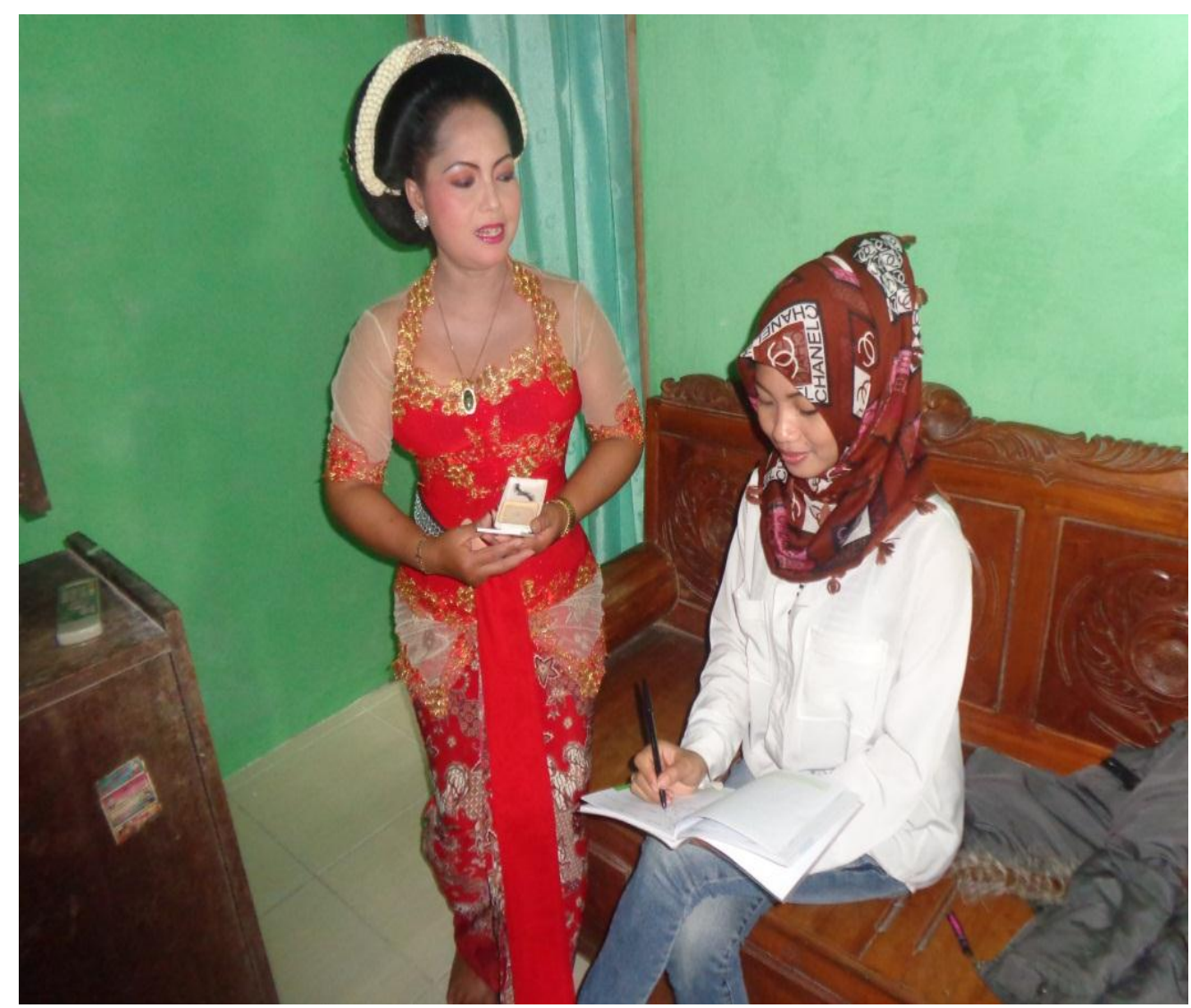

Foto 3 : Wawancara Dengan Ibu Purwaningsih (joged) 41 tahun.

(Dokumentasi : Ayu, Oktober 2015) 
Wawancara dengan Bapak supandri pengibing pada Oktober 2015

di arena pertunjukan.

Nanggap Tayub iku nek jogete gak ayu, pinter nyanyi, semok do wegah nanggap mbak, soale wong kene ki hobine do Tayuban roto-roto. Tapi nek cah nom-nom yo sitik sing melu ngibing, paling teko do nonton karo do tuku ngume mabuk, masale nek ono tanggapan Tayuban iku ditututi bakul minuman, sing diiderno ning wong sing do ameh tayuban. Dicawisi sisan diilingno ning gelas. Cah nom noman kene ki sing gak seneng Tayub paling yo sing sekolah ngasi SMA, nanging yo ono sing latian dadi panjak iku biasane sing lulusan SD SMP.

"Mengadakan pertunjukan Tayub itu kalau penarinya tidak cantik, bisa menyanyi dan mempunyai tubuh yang padat berisi maka masyarakat tidak tertarik untuk mengadakan pertunjukan Tayub. Sebab masyarakat sekitar sini rata-rata gemar Tayuban. Tapi kalau pemuda hanya sedikit yang suka Tayuban, mungkin datang untuk sebagai penonton atau hanya untuk membeli minuman keras diarena pertunjukan. Sebab diarena pertunjukan disediakan minuman keras dan disuguhkan oleh penjualnya. Pemuda yang tidak menyukai Tayub biasanya yang sekolah sampai tingkat atas, tapi ada juga yang ikut latihan menjadi pengiring biasanya yang putus sekolah perguruan tinggi seperti sekolah dasar atau sekolah menegah pertama saja".

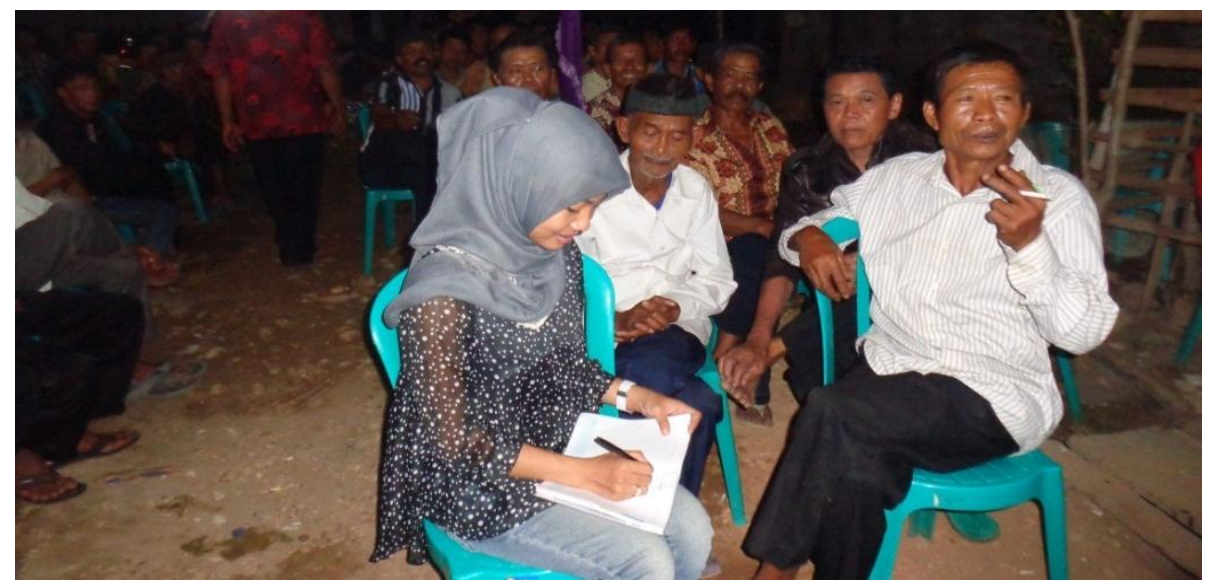

Foto 4 : Wawancara Dengan Bapak Supandri (pengibing)

(Dokumentasi : Ayu, Oktober 2015) 
Kesimpulan di atas menunjukkan bahwa berkesenian dan pendidikan sama-sama penting di dalam masyarakat Bedingin. Hal ini dapat dilihat dari hasil wawancara peneliti dengan masyarakat dan pemain seniman khususnya Tayub. Menjadi ledhek memang harus dituntut berusia belasan, jika menginjak usia dewasa ditakutkan kesenian Tayub akan punah, karena dalam pertunjukan Tayub lebih mengutamakan ledhek sebagai salah satu daya tarik yang diminati masyarakat untuk mengadakan pertunjukan Tayub. Maka dari itu kesenian Tayub di Desa Bedingin masih berkembang hingga saat ini, karena adanya generasi penerus yang dilakukan oleh para remaja.

\subsubsection{Sejarah Tayub di Desa Bedingin}

Sejarah Tayub di Desa Bedingin dilihat dari kondisi alam yang sebagian besar penduduknya adalah bermata pencaharian sebagai petani dan masyarakat percaya dengan adanya kesenian Tayub sebagai kesuburan tanah petani. Maka dari itu Tayub berkembang ke pelosok pedesaan hingga sampai di Desa Bedingin.

Adapun beberapa pendapat awal terkait kemunculan kesenian Tayub, berdasarkan wawancara dengan Ibu Purwaningsih pada Oktober 2015 selaku joged dalam pertunjukan Tayub menjelaskan bahwa:

Sejarah Desa Bedingin belum ada sejarahnya yang jelas. Tapi Tayub sudah ada pada masa Sunan Kalijaga yang mengadakan Pertunjukan Tayub di Demak sebagai tanda tasyakuran atas berdirinya Masjid yang telah didirikan oleh Sunan Kalijaga, karena menurut sejarah dari Masjid yang didirikan oleh Sunan Kalijaga kurang satu tiang penyanggah, pada akhirnya tiang tersebut dibuat dari kayu batangan yang ditumpuk hingga menyerupai ke 3 tiang yang sudah ada menjadi tiang kokoh. Hingga Sunan Kalijaga mempunyai nazar 
apabila masjid berdiri tegak dengan tiang yang terbuat dari batangan kayu tersebut maka Sunan Kalijaga akan mengadakan Toyibun sebagai rasa syukur atas berdirinya Masjid di Demak. Seiring dengan perkembangan zaman dalam masyarakat luas menyebut Toyibun dengan Tayuban. Adapula yang menjelaskan bahwa Tayub datang dari masa penjajahan yang awalnya kesenian Tayub diadakan untuk mengelabui para penjajah agar terlena dengan rayuan joged dengan disuguhi minuman keras bertujuan supaya penjajah lengah dan dapat dikalahkan.

Sri Rochana menjelaskan dalam bukunya dengan judul Tayub Blora Jawa Tengah Pertunjukan Ritual Kerakyatan (2007) bahwa, Asal mula kesenian Tayub muncul di Kabupaten Blora dari sejarah yang dapat dipakai sebagai sumber untuk mengetahui latar belakang kesenian Tayub belum kuat. Sebab pada umumnya kehidupan kesenian tradisional seperti Tayub hanya dilaksanakan secara turun temurun. Tidak ada data-data secara tertulis oleh sebagian masyarakat diakui bahwa kesenian Tayub lahir ada kaitanya dengan masa peperangan yang dilakuan oleh Raden Mas Said (Mangkunegara 1) pada awal abad ke-18. Pada masa peperangan itu Raden Mas Said sampai ke wilayah Blora. Tayub sering dipergelarkan di sela-sela peperangan yang dilakukan untuk menghibur prajurit dan sekaligus menumbuhkan semangat untuk berperang bagi para prajurit.

Penyebaran kebeberapa desa ini terjadi karena adanya kebiasaan mengamen (mbarang) dari rumah satu kerumah yang lain dari desa satu ke desa yang lain. Mereka berkeliling desa dengan cara menawarkan jasa kepada penduduk desa yang akan menanggap atau keliling desa dengan cara memasuki rumah satu kerumah yang lain. Tradisi mengamen itu memudahkan 
perkembangan dan penyebaran Tayub, sehingga hampir disetiap desa memiliki pendukung Tayub.

Kesenian Tayub di Desa Bedingin termasuk primadona yang masih digemari serta sering dipertunjukan, Tayub mampu mempromosikan dengan cara mengembangkan iringan bervariasi yang lebih menarik perhatian masyarakat dan juga didukung oleh seniman pelaku. Dengan adanya masyarakat yang ikut membantu mengembangkan kesenian Tayub dihati penggemarnya, maka Tayub tidak akan punah dan akan terus berkembang.Tayub mampu berkembang keberbagai daerah sekitar Blora dan memiliki penggemar-penggemar yang sangat fanatik. Wawancara dengan Bapak Kacung Saputra wirosuworo Oktober 2015.

Kesimpulan dari paparan di atas bahwa kesenian Tayub yang berada di Desa Bedingin belum ada kepastian tentang sejarah kemunculan Tayub yang sebenarnya. Hanya saja Tayub mampu berkembang sampai ke wilayah Kota Blora dan sekitarnya karena adanya kebiasaan ngamen dari rumah satu ke rumah yang lainya. Tayub mempunyai penggemar yang sangat fanatik karena Tayub mampu mengembangkan iringan yang bervariasi.

\subsection{Bentuk Pertunjukan}

\subsubsection{Deskripsi pertunjukan Tayub Desa Bedingin Kecamatan Todanan} Kabupaten Blora.

Tayub merupakan kesenian tradisional yang kian ditinggalkan oleh anakanak muda, dengan masuknya modern dan alat-alat musik modern ke tanah air kesenian asli produk Jawa ini semakin ditinggalkan. Kesenian Tayub ini juga sempat menjadi dakwah para Wali/Da'i zaman dulu, hingga sampai saat ini masih 
dilestarikan oleh masyarakat sebagai hiburan atau sebagai tanda rasa syukur. Bentuk pertunjukan Tayub di Desa Bedingin Kecamatan Todanan Kabupaten Blora dibagi menjadi 3 tahap yaitu tahap awal pembukaan, inti dan penutup.

\subsubsection{Pembukaan}

Pertunjukan Tayub berlangsung siang hari pada pukul 14.00 WIB berakhir pada pukul 17.00 WIB dan Tayub berlangsung pada malam hari pada pukul 21.00 WIB dan berakhir pada pukul 02.00 WIB. Pertunjukan Tayub dimulai dengan klenengan awal untuk mengundang masyarakat untuk berdatangan dan menyaksikan pertunjukan Tayub. Klenegan yaitu pengiring menabuh gamelan dengan nyanyian Jawa yang dinyanyikan oleh wirosuworo, klenengan dilakukan berulangkali bertujuan utuk mengingatkan para joged agar segera bersiap untuk naik ke atas panggung. Sebelum joged naik keatas panggung, pengrawit dan wirosuworo melakukan kondangan atau syukuran makan bersama yang telah didoakan bersama-sama, dengan makanan yang berupa nasi tumpeng dan ayam ingkung (ayam sesaji) beserta sayuran.

Klenengan kedua dilakukan setelah kondangan selesai pengiring membawakan gendhing seperti bowo pangkur, sinom dan caping gunung yang dinyanyikan oleh wirosuworo bertujuan mengumpulkan masyarakat untuk dapat ikut menikmati dan menyaksikan pertunjukan Tayub. Klenengan merupakan iringan gendhing yang dilantunkan oleh para pengrawit. Pertunjukan dimulai dengan joged membawakan lagu satu atau dua lagu untuk menandakan bahwa Tayub akan segera dimulai dan dilanjutkan dengan gambyongan. 
Menari gambyong dalam pertunjukan Tayub di Desa Bedingin menggunakan gambyong pareanom. Pada gambyongan berlangsung tidak semua joged ikut menari bersama, biasanya salah satu joged tertua duduk dan menyanyi atau menjadi sinden di belakang penari mengiringi tari gambyong.

Gambyong pembuka acara pertama pengarih menunjuk seseorang yang punya hajad beserta kerabat atau saudara untuk membuka acara dengan menari bersama joged, bermaksud bahwa pertunjukan Tayub telah dimulai dan dibuka untuk tamu undangan atau masyarakat yang ingin berpartisipasi dalam pertunjukan Tayub, yang disajikan untuk masyarakat banyak agar dapat dinikmati bersama karena Tayub merupakan tarian kerakyatan.

Sebuah pertunjukan Tayub terdapat peraturan apabila tamu undangan ingin menjadi penari laki-laki mereka harus mendaftar terlebih dahulu kepada orang yang bertugas mencatat daftar calon pengibing yang disebut pengarih kemudian catatan tersebut diserahkan kepada pranatacara untuk dipanggildan menari bersama joged.

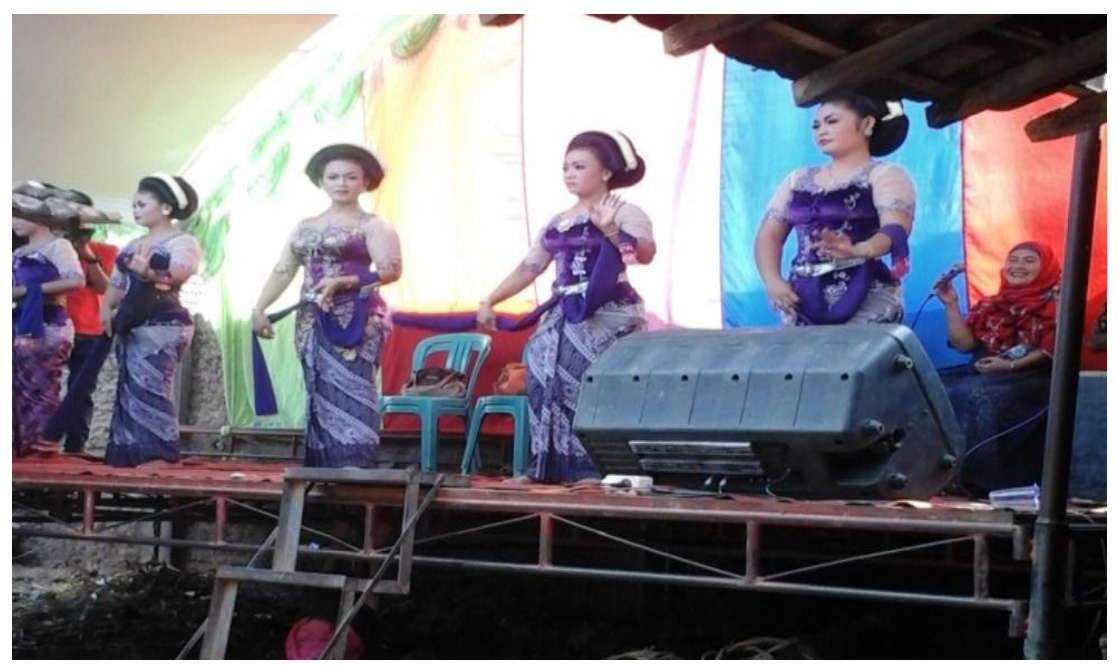

Foto 5 : Penari Gambyong dan Sinden

(Dokumentasi : Ayu, Oktober 2015) 
Keterangan :

Keterangan dalam foto 5 menunjukan joged sedang menari gambyong, tampak seorang sinden yang duduk di belakang para joged yang sedang menyanyikan sebuah lagu Jawa, namun sinden tersebut tidak menggunakan kostum seperti joged lain, dikarenakan sinden sudah tidak lagi berprofesi menjadi joged, beliau bernama Sutinah dari Pati berusia 48. Sutinah berpartisipasi menjadi sinden karena yang punya hajat termasuk masih kerabatnya sendiri.

\subsubsection{Inti}

Pelaksanaan dalam Tayuban, joged bertugas untuk menari dan bernyanyi Jawa. Gerak yang digunakan spontanitas gerak Tayub lebih mengarah menyerupai gerak tari surakarta putri. Orang yang pertama menari bersama joged biasanya orang yang punya hajat atau orang-orang yang mempunyai status sosial atas seperti perangkat desa setelah itu baru disusul oleh para pengibing yang diperankan oleh masyarakat lainya yang sudah mendaftar kepada pengarih tentunya.

Teknis dalam Tayuban dengan cara 1 penari perempuan (joged) dengan 2 penari laki-laki (pengibing) yang menari di depan dan di belakang joged. contoh 5 joged 10 penari laki-laki yang 5 menjadi pambekso menari di depan joged menggunakan sampur dan 5 sebagai pangguyup yang menari di belakang joged tidak menggunakan sampur. Setelah menari bersama mendapat satu rambahan gendhing, pengibing (pambekso dan pangguyub) berpindah tempat memutar kekanan setengah lingkaran 180 derajat searah jarum jam. Sedangkan para joged 
hanya mengubah arah hadapnya ke belakang saja sehingga tetap berhadapan dengan pambekso dan tidak menghadap pangguyup.

Pada sajian kedua sampur pambekso dikembalikan kepada joged, selanjutnya dari joged memberikan sampur tersebut kepada pangguyup sehingga pangguyup menjadi pambekso dan pambekso menjadi pangguyub. Pertukaran dalam Tayuban sudah menjadi tradisi zaman dahulu dimaksutkan agar pengibing tidak saling berebut untuk menari bersama joged.

Setelah sajian dalam sesi pertama dan kedua, maka dilanjutkan dengan pranatacara memanggil lagi calon-calon pengibing yang sudah mendaftar untuk selanjutnya naik keatas panggung menari bersama joged, setelah pambekso dan pangguyup sudah siap, maka pengibing dipersilahkan untuk meminta gendhing kepada joged dan pengrawit dan selanjutnya persiapanpun dimulai Tayuban pertunjukan ini berkelanjutan hingga berakhirnya acara Tayuban.

Gendhing-gendhing atau tembang yang dibawakan joged dalam pertunjukan Tayub ada perkembangan zaman sekarang ini mulai mengikuti permintaan pasar, dalam artian lagu-lagu atau gendhing tembang Jawa merebah ke lagu campursari kreasi dan dangdut dilakukan agar masyarakat tidak merasa bosan pada kesenian Tayub yang terkesan monoton.

\subsubsection{Penutup}

Pada bagian penutup dalam acara pertunjukan Tayub biasanya berhubungan dengan waktu yang sudah tidak memungkinkan pertunjukan berlangsung lagi, pengarih mengumumkan pertunjukan akan segera berakhir 
sebelum gendhing terakhir dilantunkan. Gendhing yang disajikan terakhir tersebut menggunakan gendhing langgam pamitan.

Dapat ditarik kesimpulan keberlangsungan pertunjukan Tayub melalui tahap pembukaan, inti dan penutup. Bagian pembukaan Tayub dilakukan klenengan, kondangan, gambyongan, dilanjutkan dengan penanggap ngibing bersama joged (Tayuban) untuk menandakan Tayub telah dibuka untuk dinikmati masyarakat. Tayub pada bagian inti yaitu Tayuban yang dilakukan oleh pengibing dengan joged diiringi dengan gendhing oleh pengrawit, Tayuban dilakukan sesi pertama dan sesi kedua. Bagian penutup wirosuworo mengumumkan bahwa pertunjukan Tayub telah selesai dan melantunkan gendhing terakhir langgam pamitan.

Wawancara dengan wirosuworo Bapak Kacung Saputro Oktober 2015

Bagaimana tahap-tahap pertunjukan Tayub dari awal hingga akhir, pertunjukan Tayub diawali klenengan pertama, mengundang masyarakat, setelah itu kondangan dilanjutkan klenengan lagi agar joged segera naik kepanggung. Setelah itu gambyongan lanjut penanggap nari bersama joged tujuannya buka acara. Bagian inti Tayuban, Tayuban habis satu gendhing, joged mutar hadap belakang diikuti pembekso dan pengibing seterusnya begitu, bagian penutup saya mengumumkan pertunjukan selesai diakhiri dengan gendhing pamitan.

\subsubsection{Penyajian Dalam Kesenian Tayub}

Penyajian dalam pertunjukan Tayub memiliki elemen-elemen pertunjukan Tayub seperti pemain, tata busana, tata rias, iringan, tempat penyajian, pengibing, penonton dan tamu undangan. 


\subsubsection{Pemain Atau Pelaku}

Pemain atau pelaku dalam pertunjukan Tayub terdiri dari joged, pranatacara, pengibing, pengarih atau pramugari dan pengrawit atau panjak

\subsection{Joged}

Joged adalah sebutan penari perempuan dalam pertunjukan Tayub di Desa Bedingin, pada umumnya joged adalah seorang penari yang dianggap sebagai pemeran utama dalam pertunjukan Tayub, tanpa adanya joged Tayub tidak akan hidup. Sebagai seorang joged harus mampu melakukan pertunjukan Tayub seperti menyanyi dan menari, oleh karena itu joged dianggap sebagai penari yang menjadi daya tarik pertunjukan agar para penikmat tertarik untuk berpartisipasi dalam pertunjukan Tayub dengan menari bersama atau Tayuban. Maka dari itu joged harus tampil sumeh, luwes, kenes dan berpenampilan menarik.

Pertunjukan Tayub dapat diperankan dengan minimal 3 orang joged, yang dianggap cukup mampu untuk meramaikan acara pertunjukan. Tayub adalah tari berpasangan, Tayub dianggap sebagai tari rakyat atau tari masal, maka dari itu biasanya pertunjukan Tayub dipentaskan semeriah mungkin dengan menghadirkan joged lebih dari tiga. Joged dalam pertunjukan Tayub biasanya berusia 14-30 tahun, perempuan dengan usia sebatas itu secara fisik mempunyai tubuh yang ideal. sementara usia 30-47 dianggap sebagia penari senior yang lebih berpengalamaan menjadi joged. Joged yang berusia 14 tahun biasanya tidak meneruskan ke jenjang perguruan tinggi, joged pada usia 14 tahun mempunyai perawakan yang besar atau bongsor sehingga memenuhi kriteria sebagai penari Tayub atau joged. 
Menjadi joged biasanya berpendidikan terakhir tamat SD maupun SMP saja, salah satunya adalah Ibu Purwaningsih yang memulai menjadi joged pada usia 14 tahun hingga saat ini berusia 41 tahun masih eksis menggeluti dunia Tayuban. Masa kerja yang cukup lama membuat Ibu Purwaningsih sudah berpengalaman menjadi joged. Penari Tayub ini tidak memiliki kelompok atau grup seperti kesenian kethoprak atau yang lainnya. Penari Tayub tidak satu pakem, melainkan pelaku Tayub adalah pekerja free lance. Pelaku Tayub dalam melaksanakan tugas dibantu dan didukung oleh pranatacara (pembawa acara) dan pengrawit.

Para tamu undangan dapat meningkat atau lebih banyak dikarenakan ikut berperperan aktifnya para tamu undangan atau masyarakat dalam pertunjukan Tayub tersebut. Pengibing atau penayub sendiri adalah penampilan penari pria bersama joged dalam pertunjukan Tayub. Pengibing diberi sampur oleh joged, dalam pertunjukan Tayub sampur sebagai properti untuk menari bersama joged. Sampur kehormatan pertama diberikan kepada Kepala Desa atau pejabat tertinggi yang hadir dalam pertunjukan tersebut. Setelah selesai para pejabat menari bersama joged, selanjutnya tamu undangan atau masyarakat yang sudah mendaftarkan diri kepada pengarih (orang yang bertugas mencatat tamu yang ingin menjadi Tayub) dan selanjutnya akan dipanggil pranatacara untuk menari bersama joged. Antusias tamu undangan membuat minat masyarakat menjadi lebih tinggi. Gerak pengibing cenderung sederhana, bebas dan mudah menyesuaikan irama gendhing yang mengiringi. 
Pranatacara dibagi menjadi dua, yaitu wirosuworo dan pengarih adalah seseorang yang mengatur jalannya atau kelancaran pertunjukan Tayuban. Pranatacara dilakukan oleh 2 orang laki-laki. Pranatacara mempunyai berbagai tugas selain menyanyi bersama joged, antara lain sebagai penghubung antara penonton atau tamu undangan dengan joged dan pengrawit. Satu diantaranya bertugas dibawah panggung untuk mencatat, mempersilahkan penonton atau calon pengibing yang akan menari bersama joged dan mengatur jalannya pertunjukan Tayub. Selain itu juga mengawasi berlangsungnya pertunjukan Tayub dan bisa menghentikan jalannya pertunjukan Tayub ketika kondisinya sudah kacau (terjadi kerusuhan). Wawancara dengan pak Nandar pengarih Oktober 2015

Apa tugas anda dalam pertunjukan Tayub, Aku kerjo dadi pranotocoro mbak, seperti apa tugas pranotocoro, pranotocoro ono loro (2) sijine dadi wirosuworo sing nyanyi ning nduwur panggung karo ngandani panjak nek ono wong njaluk gendhing, karo dadi tukang nyeluki calon wong mbeso utowo ngumumke tiap informasi, mboh ono tukaran, mboh ono sing kelangan lan liyo liyone. Pranotocoro sijine dadi pengarih sing tukang ntayeti calon wong mbeso, tugase ning ngisor panggung terus catetane tak wehno wirosuworo ben dipanggil nganggo mik, apa yang anda lakukan jika terjadi kerusuhan, Pranotocoro ngawasi uwong uwong nek ono sing rese mengko sing tanggung jawab yo aku karo wirosuworo, berusaha melerai utowo ndamaino

Saya bekerja sebagai pranotocoro mbak, pranatacara terbagi menjadi dua. Pertama sebagai wirosuworo yang menyanyi diatas panggung dan bertugas menghubungkan antara penonton dengan pengrawit jika penonton meminta lagu. Tugas wirosuworo juga mengumumkan setiap kejadian informasi dalam kelangsungan pertunjukan Tayub, bisa info kerusuhan, berita kehilangan dan lainlain. Salah satu pranotocoro lain yaitu pengarih yang bertugas dibawah panggung untuk mencatat calon pengibing, seterusnya akan saya serahkan catatan nama-nama calon pengibing kepada wirosuworo agar diumumkan melalui mic. Pranatacara juga mengawasi orang-orang yang bermasalah, nanti yang bertanggung jawab saya dengan wirosuworo, saya berusaha melerai atau mendamaikan. 


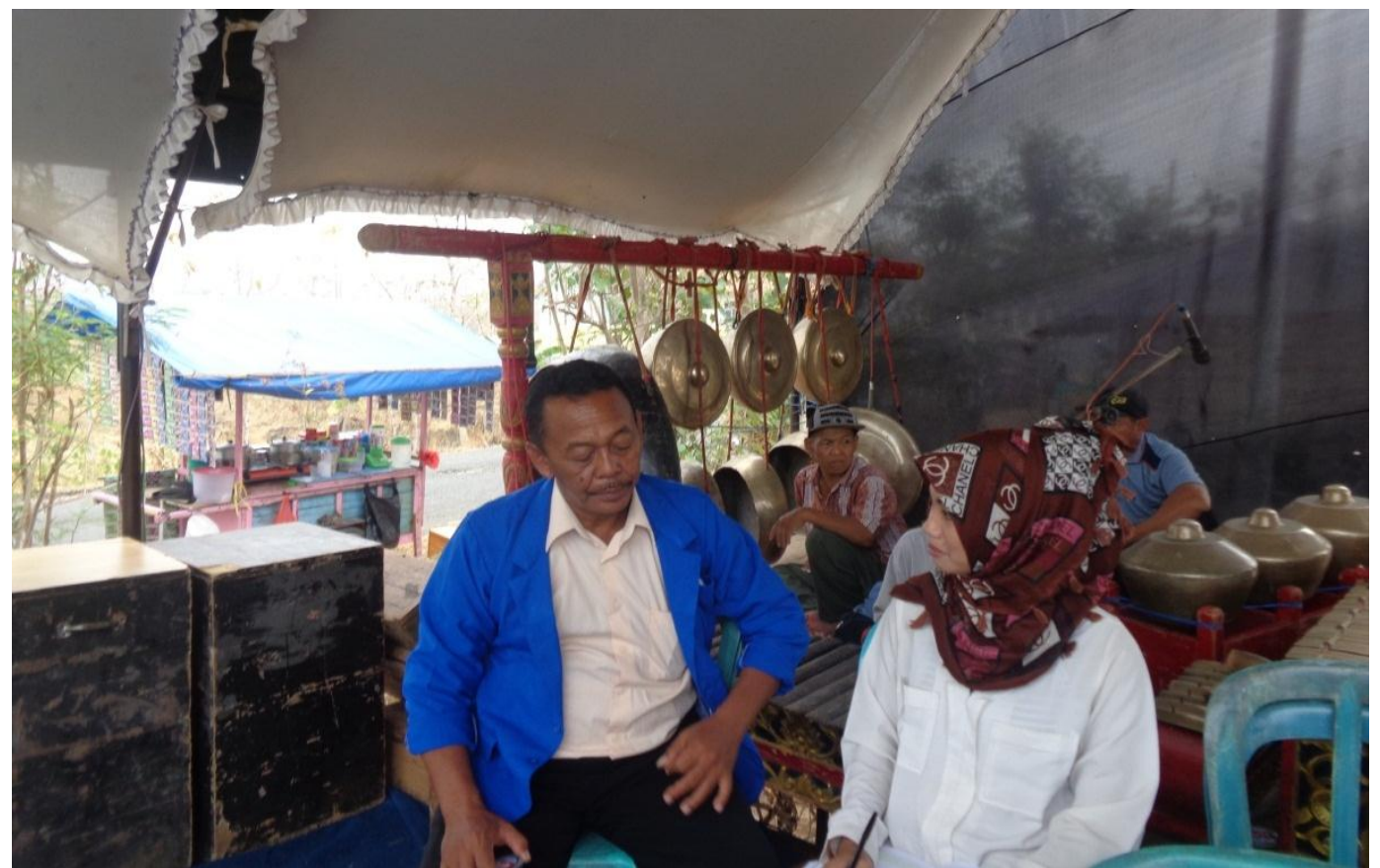

Foto 6 : Wawancara Dengan pengarih

(Dokumentasi : Ayu, Oktober 2015)

Pengrawit bertugas untuk menabuh gamelan dalam mengiringi joged menyanyi atau menari dalam sebuah pertunjukan Tayub. Para pengrawit khususnya dalam pertunjukan Tayub perlu memiliki keahlian harus dapat menguasai gendhing-gending Jawa klasik maupun kreasi baru sesuai dengan perkembangan zaman masa kini.

\subsection{Tata Rias Dan Busana}

Sebagai penari Tayub, dituntut untuk terlihat cantik dan menarik dan juga mempunyai daya tarik sendiri, daya tarik yang terpancar dari wajah joged yaitu dengan cara merias wajah. Rias merupakan hal terpenting dalam mendukung sebuah sajian seni tari. Rias yang digunakan oleh para joged yaitu dengan rias korektif yang artinya cenderung lebih tebal, karena rias sebagai salah satu hal yang paling peka dan utama dihadapan penonton atau penikmat Tayub. Penikmat 
Tayub, penonton dan pengibing biasanya melihat paras joged terlebih dahulu sebelum menikmati Tayuban.

Rias yang digunakan joged merupakan rias panggung, lebih tajam dibanding dengan rias sehari-hari. Hal itu nampak pada penggunaan bedak, pemakaian pensil alis, bayangan pada kelopak mata, pemerah pipi, pemerah bibir dan juga menggunakan bulu mata. Rias yang dipertebal akan membuat karakter joged menjadi terlihat cantik, penggunaan pemerah pipi dan juga pemerah bibir berfungsi sebagai riasan wajah agar terlihat lebih segar dan tidak pucat.

Proses sebelum penyajian joged pada tahap awal kegiatan terlebih dahulu mempersiapkan segala perlengkapan seperti makeup dan busana yang akan digunakan. Joged menggunakan rias yang berwarna mencolok yang bertujuan agar terkesan cantik, menarik dan lebih menegaskan karakter yang dibawakan.

Sanggul yang digunakan joged adalah sanggul soloputri, sebelum menggunakan sanggul biasanya joged menyasak rambutnya agar tampak lebih tinggi dan membentuk sunggar diatas kedua telinga, setelah itu sanggul baru dipasang beserta hiasan rambut. Hiasan rambut bisa berupa bunga melati, jamang ataupun cunduk mentul. Joged tanpa malu-malu seringkali memperbaiki riasan wajahnya disela-sela pertunjukan untuk mempertahankan rias wajahnya agar tetap terlihat cantik.

Pemakaian tata busana bermaksud untuk memperjelas peranan dan karakter yang dibawakan dalam pertunjukan Tayub. Kostum joged menggunakan kebaya modern tertutup dengan lengan pendek dilengkapi kain jarik wiru tengah (wiron). 
Penggunaan slepe atau sabuk yang diikatan sebagai penutup pada pinggang yang sebelumnya telah dikaitkan sampur yang melingkar diperut. Warna yang dipilih joged adalah dominan kuning kemerahan karena sesuai dengan watak tarian Tayub yang lincah. Selain slepe tidak boleh ketinggalan properti dalam menarik Tayub yaitu sampur (selendang).

Sampur (selendang) sebagai pelengkap didalam pertunjukan Tayub dengan warna bentuk dan corak yang bebas. Namun demikian sampur yang digunakan terbuat dari bahan sifon warna polos dengan menggunkan monte atau rumbai-rumbai untuk memperindah sampur. Gerakan sampur menggoyang rumbai-rumbai diujung sampur sangat menarik untuk dilihat dan kerlipan rumbairumbai yang terkena cahaya memberikan suasana gemerlap yang kemudian memantulkan diwajah joged merupakan daya pesona sendiri dari sebuah tarian Tayub.

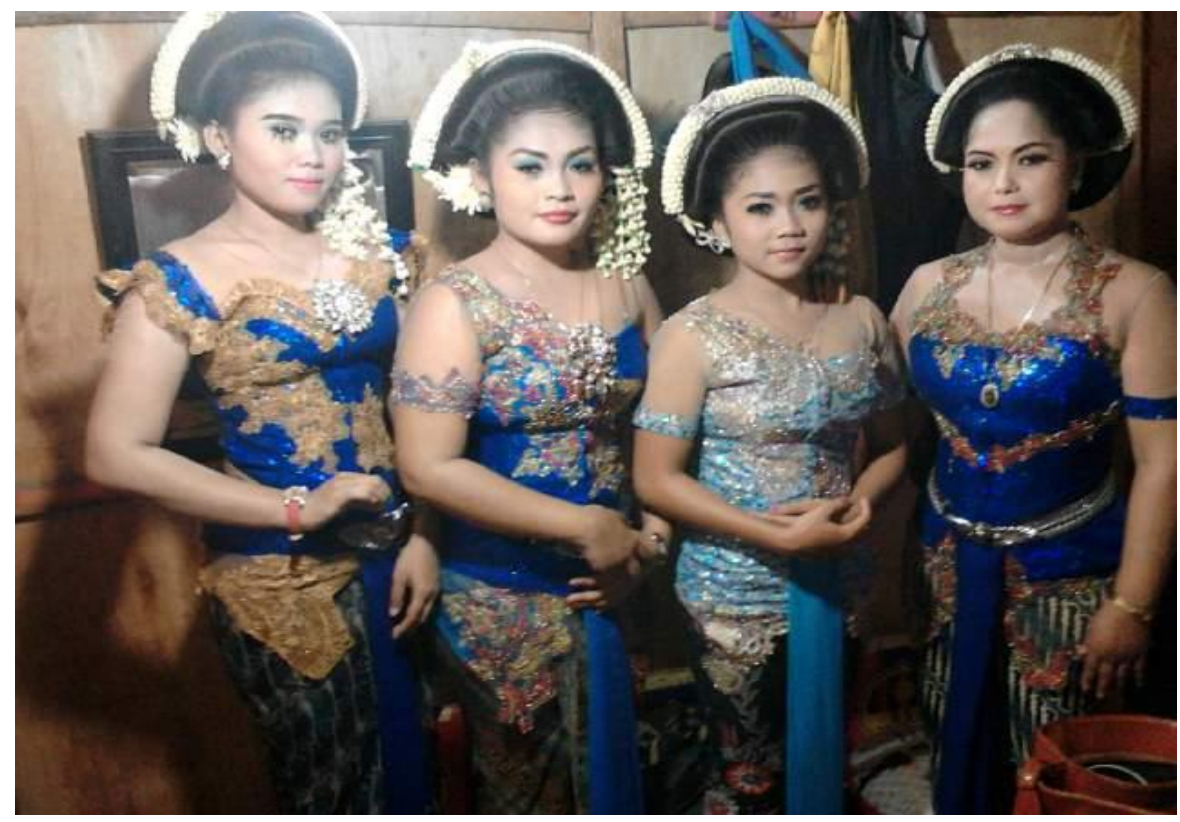

Foto 7 : Penari Tayub (joged)

(Dokumentasi : Ayu, Oktober 2015) 
Keterangan :

Keterangan foto 7 menunjukan karakter rias cantik dan kostum yang digunakan oleh joged.

Cara pemakaian busana, pertama joged menggunakan jarik yang sudah diwiru sebelumnya dengan cara melilitkan dari pinggul sampai diatas mata kaki hingga wiru tepat berada ditengah dan rapi, kemudian dibalutkan stagen untuk mengencangkan jarik supaya kencang, secara rapi diperut sampai pinggang, dikaitkan dengan peniti agar jarik dan stagen tidak lepas. Selanjutnya, pakai strepes atau tarso (pembentuk tubuh bagian pinggul sampai bagian dada) kemudian padukan dengan kebaya modern. Setelah busana dipakai, pasangkan aksesoris pada pinggang yakni sampur yang diikatkan melingkar pada perut dan terurai panjang didepan. Diluar sampur dipasang slepe atau sabuk diikatkan dengan epek timang. Bagian terakhir memakai perhiasan yaitu kalung pada leher, gelang dan anting.

Busana pranatacara cukup sederhana yaitu pemakaian baju adat Jawa lengan panjang (beskap) dan pemakaian jarik atau kain motif batik yang dililitkan pada tubuh bagian bawah. Pada bagian kepala menggunakan blangkon sebagai penutup kepala. Namun, pranatacara dalam pertunjukan Tayuban tidak menggunakan jarik, melainkan menggunakan celana kain warna hitam, dan memakai jas dan selop sebagai alas kaki. Biasanya pada bagian kepala tidak menggunakan blangkon atau penutup kepala, hanya ada salah satu pranatacara menggunakan udeng sebagai penutup kepala, tujuannya hanya fashion belaka 
(wawancara dengan Bapak Cepres pengarih). Hal ini dimaksudkan agar pranatacara terkesan gagah, rapi dan berwibawa dalam pembawaan karakter.

Busana untuk pengrawit menggunakan beskap dan blangkon, pengrawit juga menggunakan jarik. Busana penari pria atau pengibing lebih sederhana karena Tayuban ini merupakan tarian tradisional yang dimiliki oleh masyarakat pedesaan yang kebanyakan kehidupannya adalah seorang petani menggunakan kemeja, hem, celana panjang, kaos, topi dan alas kaki berupa sandal.

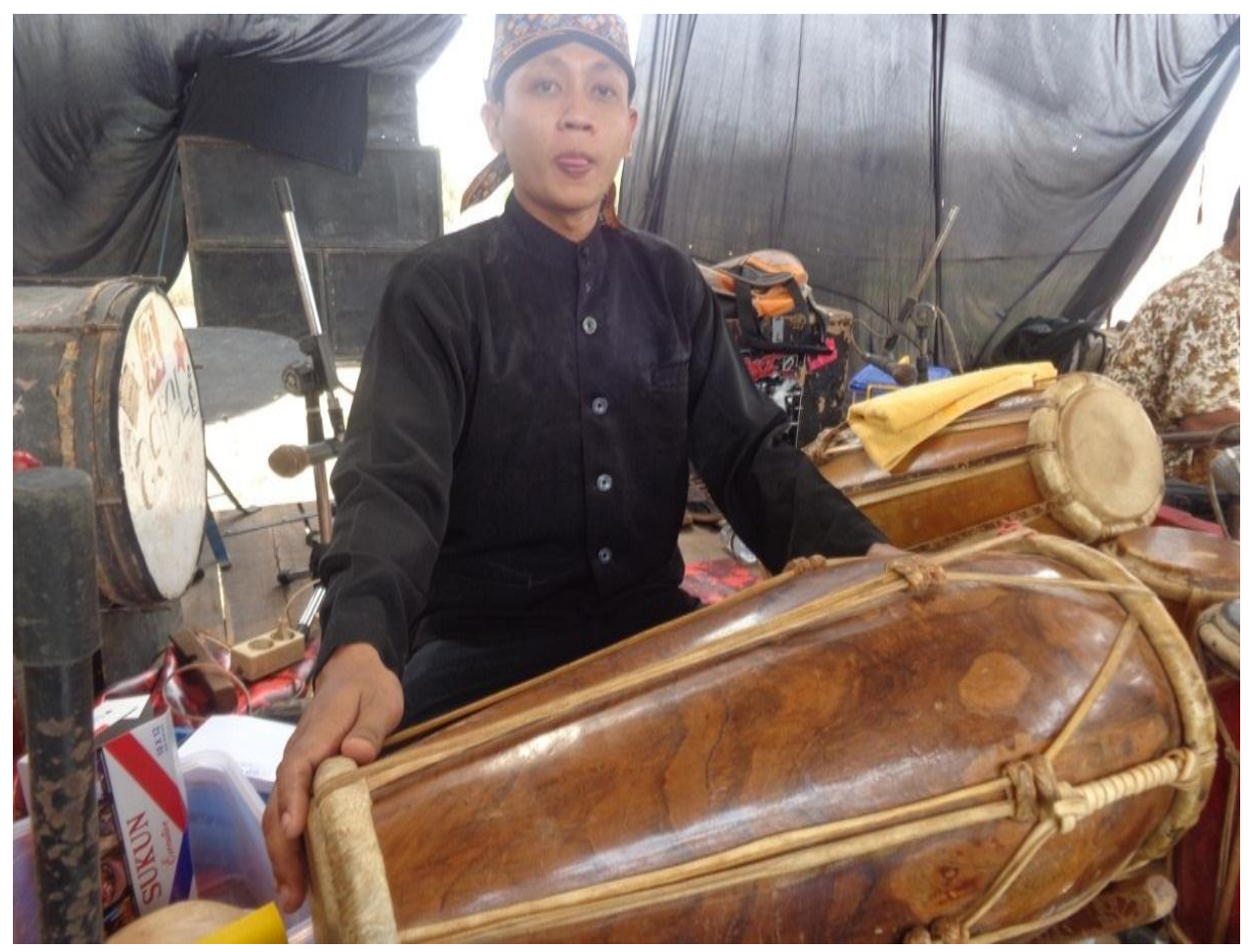

Foto 8 : Agil, Ketua Paguyuban

(Dokumentasi : Ayu, Oktober 2015)

Keterangan :

Keterangan foto 8 terlihat Agil berusia 30 tahun yang merupakan ketua paguyuban Agil Manunggal yang sedang memainkan kendhang dalam pertunjukan Tayub dan menggunakan kostum berupa beskap dan blangkon. 


\subsection{Iringan}

Iringan yang digunakan Tayub adalah seperangkat gamelan Jawa dengan laras slendro dan pelog. Dalam penggunaannya ditabuh secara bergantian. Seperangkat gamelan Jawa yang lengkap terdiri dari 17 jenis instrumen seperti Bonang Barung, Bonang Penerus, Slenthen, Kendhang Jawa (Ciblon), Kendang Jaipong, Gender, Kethuk, Kenong, Saron Barung, Saron Penerus, Demung, Gong, Kempul, Ketipung, Gambang, drum dan simbal. Alat-alat tersebut berbeda satu dengan yang lainya, tetapi bergabung sehingga menghasilkan sebuah irama yang sangat indah.

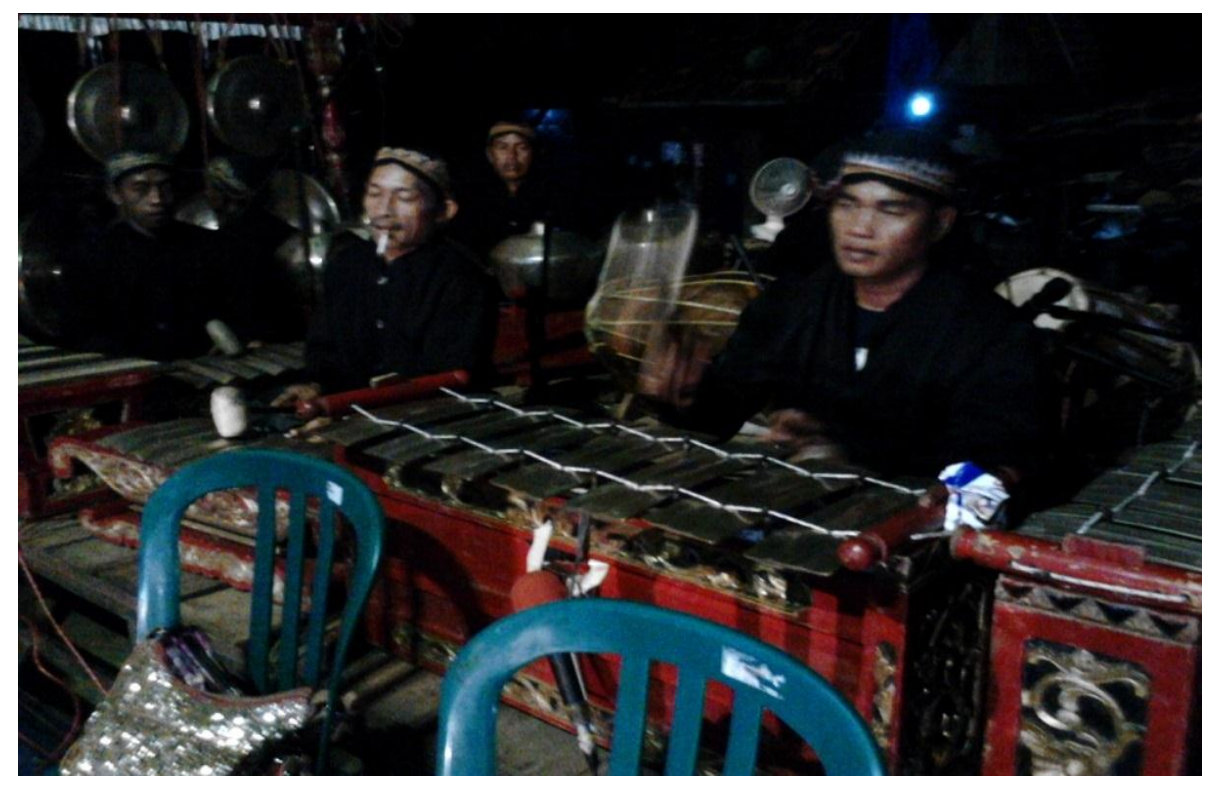

Foto 9 : Pengrawit Tayub

(Dokumentasi : Ayu, Oktober 2015)

Keterangan:

Keterangan foto 9 terlihat pengrawit sedang memainkan gamelan Jawa. Namanama pengrawit yang bertugas mengiringi pertunjukan Tayub paguyuban Agil Manunggal antara lain : Pak Agil memainkan kendhang sekaligus ketua paguyuban, Pak Nunuk memainkan saron, Pak Bambang memainkan peking, Pak 
Sanuri memainkan bonang, Pak Darno memainkan bonang penerus, Pak Wisnu memainkan gambang, Pak Parjo memainkan gong gedhe, Pak Nyamat memainkan kenong, Pak Siran memainkan jedor, Pak Topo memainkan demung dan Pak Warso memainkan siter.

Karawitan mempunyai peran yang sangat penting dalam pertunjukan Tayub, sebagai penentu lagu dan irama adalah instrumen kendhang. Maka kendhang mempunyai peran sangat penting dalam karawitan Tayub. Karena ekspresi para penari sangat didukung oleh karawitan terutama kendhang.

Kesimpulannya bahwa musik pengiring mempunyai peran yang sangat aktif dalam pertunjukan Tayub. Pertunjukan Tayub tidak akan berjalan lancar tanpa adanya musik pengiring, karena musik pengiring dalam pertunjukan Tayub sangat menentukan ekspresi atau interaksi dalam menari bersama antara joged dengan pengibing atau disebut dengan Tayuban.

Peneliti melakukan wawancara dengan Agil selaku ketua dari paguyuban Agil Manunggal tentang siapa saja nama-nama pengiring beserta alat musik yang dimainkan, adakah alat musik yang berperan sangat aktif dalam pertunjukan Tayub.

\subsection{Tempat Pentas}

Penyajian Tayub di Blora pada umumnya menggunakan panggung yang tinggi dan terkesan mewah. Hal ini berfungsi sebagai pembahasan antara penari dan penonton agar tidak terjadi saling mengganggu satu sama lain. Penyajian Tayub agar kelihatan rapi sehingga menumbuhkan ide yaitu diadakan pembatasan jarak antara penari pria dengan joged sekitar 1 meter menurut joged Ibu 
Purwaningsih. Keuntungan lain pertunjukan di atas panggung adalah pemain berada lebih tinggi dari penonton sehingga seluruh gerak dapat dinikmati oleh penonton.

Panggung penyajian Tayub berada di atas panggung sehingga para penonton dapat menyaksikan pertunjukan Tayub dengan leluasa. Para pemain pengiring Tayub duduk lesehan beralas tikar 1/4 dari luas panggung dengan seperangkat gamelannya, sedangkan para tamu undangan duduk ditempat yang telah dipersiapkan panitia (diluar arena pentas). Joged berada di tengah-tengah arena pentas agar mempermudah para penonton dalam menyaksikan pertunjukan Tayub.

Kesimpulannya bahwa pertunjukan Tayub tertata dengan jarak pengibing dengan joged, tempat penyajian Tayub disajikan di atas panggung yang lebih tinggi dari arena penonton, agar penonton lebih leluasa untuk menikmati pertunjukan Tayub dengan leluasa. Pemain pengiring bertempat dari 1/4 panggung di belakang tempat duduk joged.

\subsection{Peran Masyarakat}

Identifikasi masyarakat Jawa menurut Geertz (1989) dibagi menjadi tiga golongan yang bersifat abangan, santri dan priyai. Ketiga tipe keagamaan yang berbeda yaitu Hindu-Budha dan nilai-nilai Islam. Pola interaksi antara budaya lokal dan nilai Islam menjadi Islam warna-warni.

Peran masyarakat dalam pertunjukan Tayub menunjuk pada keterlibatan masyarakat yang terdapat beberapa macam golongan, yaitu sebagai pengibing, tamu undangan, penonton dan pedagang. Selain itu masyarakat juga berperan 
sebagai penangagap (orang yang punya hajad), penikmat seni (penikmat saja), pendokumentasi, operator, pemasak dan karang tarun. Masyarakat yang terlibat dalam pertunjukan Tayub merupakan faktor pendukung yang sangat dibutuhkan keberadaannya, sebab tanpa adanya masyarakat pertunjukan tidak akan berjalan dengan lancar.

\subsubsection{Penonton}

Penonton pada pertunjukan Tayub, tidak terbatas pada usia-usia tertentu (dalam Hurlock, 2007:55-56). Suatu pertunjukan tidak akan berjalan lancar tanpa adanya penonton. Penonton dalam pertunjukan Tayub adalah orang yang datang untuk menyaksikan Tayuban ke arena pertunjukan, penonton bisa saja dari tamu undangan atau orang yang datang tanpa diundang, para penonton pertunjukan Tayub terdiri dari bapak-bapak, ibu-ibu dan anak-anak. Pada pertunjukan Tayub terjadi interaksi sosial antara joged dan penonton. Penonton datang tanpa undangan, mereka bergerombol mencari tempat dan posisi dengan sendirinya untuk menyaksikan pertunjukan Tayub dengan santai, sehingga mereka bisa menangkap apa dan bagaimana pertunjukan Tayub tersebut bisa dirasakan dalam memberikan pencerahan dalam batinya. Selain itu penonton juga dapat berpartisipasi menjadi pengibing atau penari laki-laki

Penonton di dalam pertunjukan Tayub Desa Bedingin Kecamatan Todanan Kabupaten Blora menyambut dengan ramah dan penuh kegembiraan. Masyarakat yang tediri dari bapak-bapak, ibu-ibu, pemuda-pemudi dan anak anak berkumpul diarena pertunjukan untuk menyaksikan acara pertunjukan. 


\subsubsection{Pengibing}

Pengibing adalah seorang atau salah satu tamu undangan yang mendapat kesempatan menari Tayub di atas panggung bersama ledhek atau joged (Rochana, 2007:222). Pengibing dalam pertunjukan Tayub adalah orang yang berperan sebagai penari laki-laki yang menari berpasangan dengan joged, pengibing terbagi menjadi 2 yaitu pambekso dan pangguyup. Pambekso adalah penari laki-laki yang menari di depan joged dengan menggunakan sampur, sedangkan pangguyub adalah orang yang menari di belakang joged tidak menggunakan sampur. Pambekso dan pangguyup tidak harus memiliki kemampuan menari yang baik, minimal mengerti dan peka terhadap musik karawitan, karena dengan adanya pengibing dalam pertunjukan Tayub, maka pertunjukan akan menjadi lebih ramai dan meriah. Selain itu pengibing merasa senang bisa menari bersama ledhek dan juga menghibur para penonton.

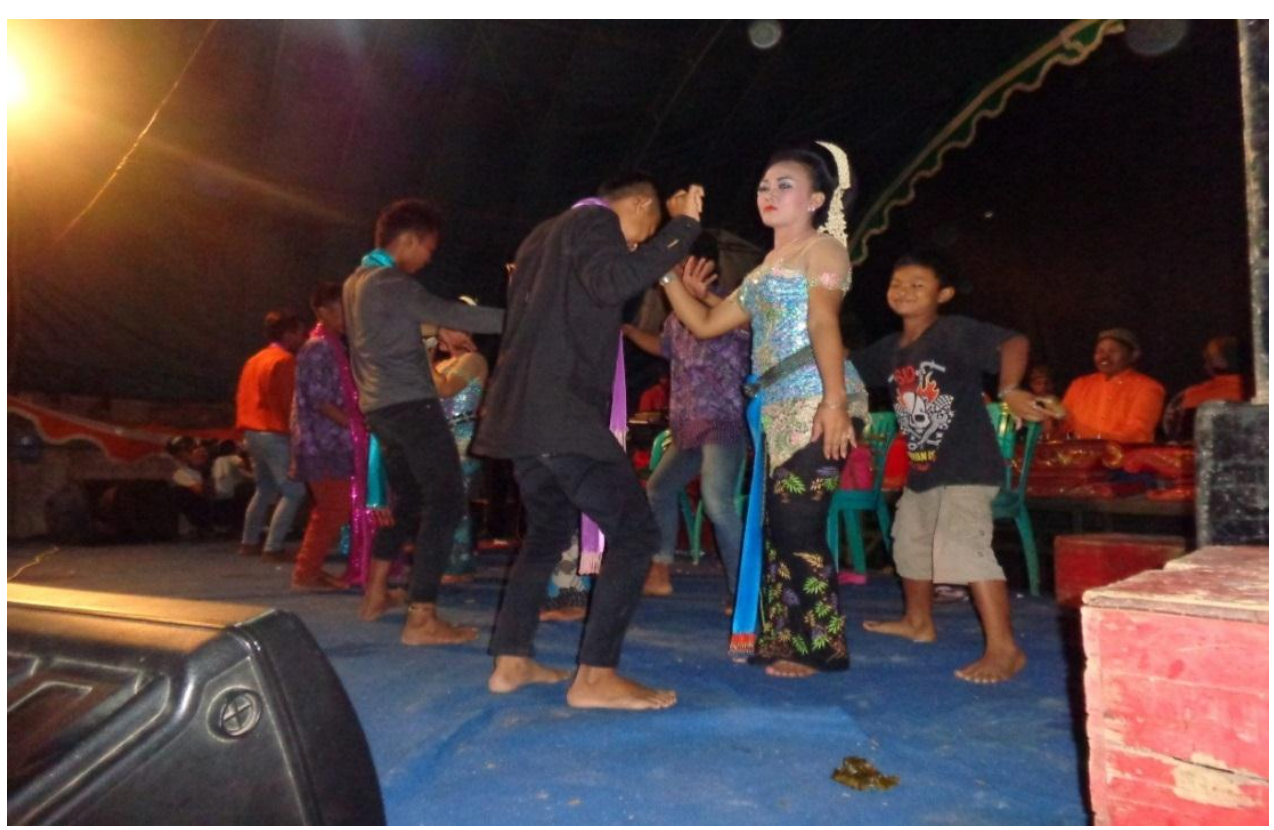

Foto 10: Anak-Anak Yang Sedang Ngibing

(Dokumentasi : Ayu, Oktober 2015) 
Keterangan :

Keterangan dalam foto 10 nampak terlihat anak-anak yang sedang melakukan kegiatan Tayuban. Hal ini menunjukan bahwa penggemar Tayub tidak hanya dari kalangan orang tua saja yang berantusias untuk menari bersama joged.

Pengibing dapat dilakukan dari kalangan tamu undangan atau penonton. Pertunjukan Tayub dalam mengibing atau Tayuban dapat terjadi adanya interaksi antara joged dengan penonton, interaksi yang didapatkan akan dinikmati oleh penonton dan dapat menghadirkan suasana romantis dalam getaran gerak dan musik karawitan. Pengibing seringkali bergerak dengan pola-pola gerak gaya surakarta secara bervariasi atau bergerak cenderung bebas seperti gerak dangdutan. Kepolosan dan keluguan dalam bergerak pada pengibing seringkali menjadi tontonan yang menarik. Adapun faktor-faktor yang menyebabkan konflik antara pengibing yang biasa terjadi yaitu karena pengaruh minuman beralkohol maka pambekso maupun pangguyup menjadi lebih sensitif dan arogan sehingga dapat menimbulkan konflik antara pengibing. Wawancara dengan penonton di Desa Bedingin Oktober 2015.

Kerusuhan dapat terjadi pada pengibing yang datang lebih awal dan sudah mendaftar lebih lama tapi tidak kunjung dipanggil, hal itu yang membuat kecemburuan antar kelompok pengibing sehingga dapat menimbulkan masalah. Penyebab utama terjadi konflik yaitu berawal dari minuman beralkohol yang dijual diarena pertunjukan Tayub secara terang-terangan.

Adakah kerusuhan yang terjadi pada saat pementasan Tayub berlangsung, kerusuhan terjadi antar siapa dan siapa, adakah pemicunya, siapa yang bertanggung jawab atas terjadinya kerusuhan, kerusuhan terjadi antara pengibing dengan pengibing 
yang lain, karena pengibing yang sudah mendaftar terlebih dahulu tidak kunjung dipanggil, dari situlah terdadinya kerusuhan karena pengibing ada yang mengkonsumsi alkohol, sehingga mereka tidak sadar atau mabuk, karena pertunjukan Tayub selalu diikuti pedagang minuman keras. Kerusuhan dipertanggung jawabkan oleh pengarih dengan cara berusaha melerai dan mendamaikan sehingga pertunjukan dapat dinikmati kembali.

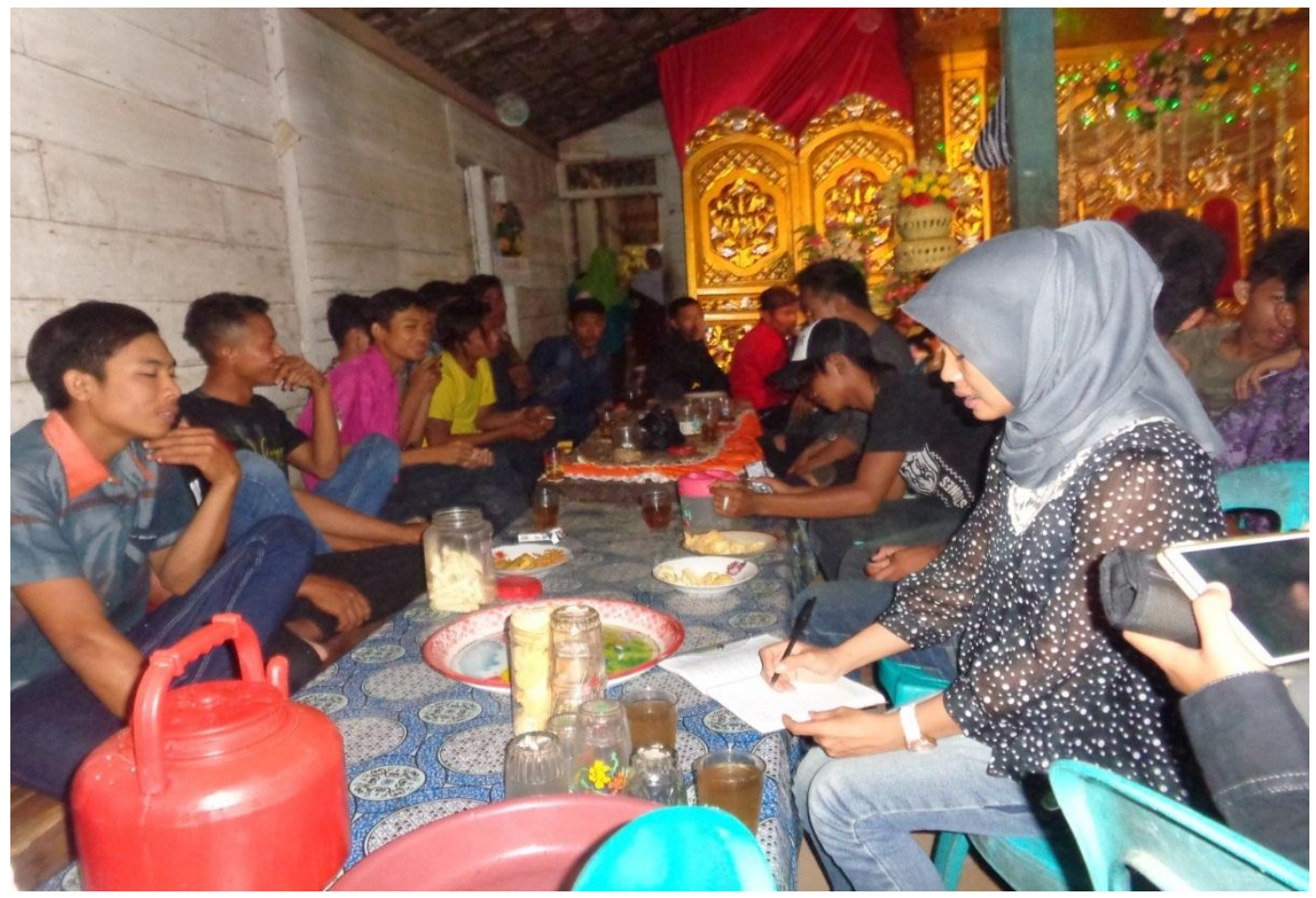

Foto 11: Wawancara Dengan Penonton

(Dokumentasi, Ayu Oktober2015)

Keterangan :

Keterangan dalam foto 11 terlihat peneliti sedang melakukan wawancara dan mencatat isi wawancara dengan salah satu penonton tentang tarjadinya konflik dalam pertunjukan Tayub.

\subsubsection{Tamu Undangan}

Tamu undangan dalam pertunjukan Tayub adalah orang yang menghadiri acara yang telah diselenggarakan penanggap. Tamu undangan biasanya berkaitan dengan penanggap, tamu undangan adalah teman dan kerabat penanggap yang 
diundang untuk ikut menikmati hiburan pertunjukan Tayub yang telah disediakan oleh penanggap, tamu undangan bisa saja orang yang akan ikut berpartisipasi menari bersama joged, namun tidak semua tamu undangan bisa menari.

Dapat ditarik kesimpulan bahwa tamu undangan adalah orang yang mendapat panggilan untuk datang diacarapertunjukan Tayub sebagai penikmat Tayub atau penonton.

\subsubsection{Pedagang}

Pedagang dalam usahanya menggunakan perlengkapan mudah dibongkar pasang, pedagang berusaha dibidang produksi dan berjualan barang-barang untuk memenuhi kebutuhan masyarakat (Akhirudin, 1982).

Pedagang dalam pertunjukan Tayub adalah sekelompok orang yang berjualan diarena pertunjukan Tayub, sebagai salah satu kesempatan untuk menghasilan keuntungan disekitar arena pertunjukan Tayub. Pedangang tersebut seperti kegiatan pasar tiban yang hanya dilakukan jika ada pertunjukan Tayub. Penjualan dipasar tiban beraneka macam makanan dan minuman yang diperlukan oleh penonton yang hadir dipertunjukan Tayub antara lain, makanan padat seperi nasi, mie, lontong, bakso dan sate. Makanan ringan diantaranya seperti, kacang, jagung, buah, permen, roti dan lainya, ada juga yang menjual mainan anak dan pernak pernik. Para pedagang biasanya menggunakan gerobak, meja kursi panjang untuk menggelar barang dagangannya, ada juga yang berjualan dengan hanya menggelar tikar dan berjualan diatas tikar saja. 


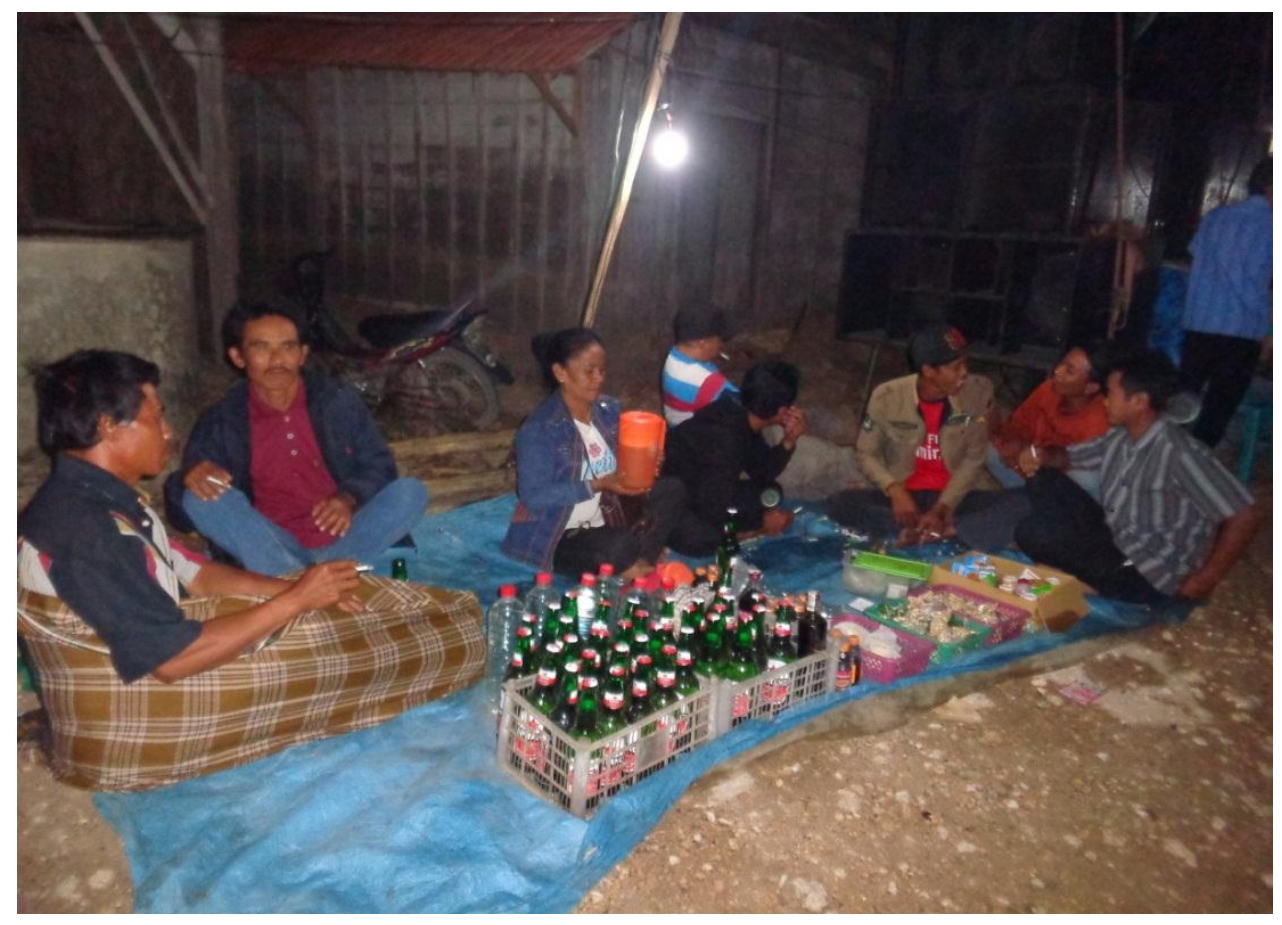

Foto 12 : Pedagang Minuman Keras

(Dokumentasi : Ayu, Oktober 2015)

Keterangan :

Keterangan dalam foto 12 menunjukkan bahwa adanya pedagang minuman keras yang ditemui peneliti dalam pertunjukan Tayub yang secara terang-terang menjual dagangannya. Serta nampak pedagang sedang mengangkat minuman yang sudah dioplos dan akan diberikan oleh konsumen.

Minuman beralkohol dalam pertunjukan Tayub di Desa Bedingin biasanya dijual secara terang-terangan karena pedagangnya berkeliling menawarkan minumanya, penjual minuman itu bersedia untuk menuangkan minumannya itu dan diberikan kepada penikmat minuman itu. Kehadiran pedangan minuman beralkohol ikut memeriahkan pertunjukan yang sedang berlangsung sebagai contoh hajatan yang dilakuakan secara sederhana bisa tampak lebih semarak dan 
meriah jika hadir penjual minuman disekitar arena pementasan. Seperti yang telah dijelaskan oleh Bapak Supandri dalam wawancara dengan peneliti.

Kesimpulannya bahwa pasar tiban dalam pertunjukan Tayub menjadi salah satu peran yang sangat penting, karena pedagang berdatangan secara berbondongbondong ke arena pertunjukan untuk menjual daganganya, selain mendapat keuntungan, pedagang juga termasuk orang-orang yang ikut menikmati acara pertunjukan Tayub, karena tanpa adanya pedagang pertunjukan akan terlihat sepi. Pedagang minuman keras sudah menjadi bagian dari pertunjukan Tayub, karena setiap diadakan pertunjukan Tayub disitulah penjual minuman keras ditemukan.

Peran masyarakat dalam pertunjukan Tayub di Desa Bedingin selain menjadi penonton, pengibing, tamu undangan dan pedagang juga terdapat masyarakat yang berperperan sebagai penanggap, penikmat seni, pendokumentasi, operator, dan karang taruna.

\subsubsection{Penangap}

Penanggap adalah orang yang mengadakan pertunjukan Tayub sebagai hiburan, nazar tasyakuran, pernikahan, khitanan atau pelepas nadzar. Keterlibatan pertunjukan Tayub dengan penanggap yaitu sebelum acara pementasan dimulai, penanggap harus menyiapkan tumpeng dan ayam ingkung untuk kondangan pembukaan pertunjukan Tayub yang akan dilakukan oleh pelaku seni. Penanggap biasanya diberi kesempatan pertama yang akan menari bersama joged sebagai tanda penghormatan dari pelaku seni diawal pertunjukan atau sebagai tanda pertunjukan telah dibuka untuk masyarakat. Penanggap juga merupakan orang 
yang bertanggung jawab atas keberlangsungan pertunjukan Tayub yaitu dengan memberi fasilitas untuk para pelaku seni dan juga pemberi upah.

Kesimpulannya bahwa penanggap orang pertama yang mendapatkan kesempatan menari bersama joged. Penanggap adalah seorang yang bertanggung jawab sebagai orang yang mengadakan acara pertunjukan, penanggap juga sebagai orang yang mengeluarkan biaya untuk keberlangsungan acara pertunjukan, yaitu sebagai seseorang yang memberi upah kepada pemain, operator, pendokumentasi, tamu undangan dan keperluan dapur.

\subsubsection{Penikmat Tayub}

Penikmat Tayub adalah orang yang datang ke arena pertunjukan sebagai tamu undangan, pengibing, penonton, pemabuk, bahkan ada juga yang datang hanya sebagai penikmat saja. Pertunjukan Tayub dalam penikmat Tayub biasanya adalah penggemar Tayub yang sangat fanatik, para penggemar Tayub biasanya selalu datang setiap kali ada pertunjukan Tayub tanpa undangan.

Kesimpulannya bahwa peran penikmat Tayub juga sebagai pemeriah acara, karena kedatangan mereka secara bersamaan tanpa undangan. Maka dari itulah penikmat Tayub disebut sebagai penggemar yang sangat fanatik.

\subsubsection{Pendokumentasi}

Pendokumentasi seseorang yang mengumpulkan data. Pendokumentasi diambil dari kata dokumentasi yang berarti mengumpulkan data dengan cara mengambil data-data dari catatan, dokumentasi, administrasi, video atau gambar. Pendokumentasi dengan petunjukan Tayub mempunyai hubungan sebagai berikut, 
pendokumentasi adalah orang yang bertugas untuk mendokumentasikan acara pertunjukan Tayub.

Pendokumentasi dalam acara Tayub merupakan orang yang mengambil gambar dengan cara memotret atau merekam pertunjukan Tayub yang sedang berlangsung. Dokumentasi dapat dilakukan dengan bentuk video maupun gambar kamera bertujuan untuk mengabadikan acara pertunjukan yang diadakan oleh penanggap. Dokumentasi yang telah dibuat biasanya akan dapat dilihat dihari kemudian oleh penanggap dan bisa saja dokumentasi dengan bentuk video dapat dibeli oleh para penggemar Tayub yang ingin mempunyai video dekumentasi pertunjukan Tayub tersebut.

Kesimpulannya bahwa peran pendokumentasi sebagai salah satu dukungan dari masyarakat sebagai, pendokumentasi yang memberikan bantuan berupa mendokumentasikan setiap acara pertunjukan dari awal hingga akhir pertunjukan. Karena dokumentasi juga dibutuhkan sebagai kenang-kenangan, untuk melihat lagi pertunjukan yang sudah berlalu. Maka dari itu peran pendokumentasi juga diperlukan dalam setiap acara.

\subsubsection{Operator}

Operator dalam pertunjukan Tayub adalah orang yang mengatur audio dan mengatur lighting. Opertor disebut orang yang mengendalikan suara besar kecilnya suara saund system. Operator juga bertugas memasang lampu-lampu untuk penerangan diarena pementasan, agar pelaku seni dapat leluasa melakukan kegiatan yang dapat menghibur masyarakat. Penerangan cahaya dan audio sangatlah membantu jalannya pertunjukan Tayub, karena cahaya yang menjadi 
penerangan pertunjukan Tayub dapat mendukung pertunjukan Tayub agar terlihat megah dan enak dipandang karena menunjukan para pelaku seni terlihat berkarakter sesuai dengan perannya masing-masing.

Audio dalam pertunjukan Tayub membuat pelaku seni dan penggemar Tayub menjadi lebih puas, karena suara gamelan dan suara nyanyian joged dan pranatacara terdengar lebih keras dan merdu, suara audio yang membuat para penggemar pertunjukan Tayub semakin mendendang dalam telinga mereka. Sehingga masyarakat dapat menikmati pertunjukan Tayub dengan puas karena suara-suara gamelan dan suara penyanyi terdengar jelas ditelinga penikmat Tayub. Maka dari itu audio dalam pertunjukan Tayub sangat membantu dan mendukung untuk kelancaran acara Tayuban.

Kesimpulan bahwa peran operator dalam pertunjukan Tayub juga sangat menguntungkan. Peran operator sebagai penata cahaya, audio suara, semua itu sangat dibutuhkan dalam suatu acara apapun. Peran operator membantu dalam keberlangsungan pertunjukan Tayub, karena operator mampu membantu memasang lampu sebagai penerangan dan mengaktifkan audio suara sebagai pengeras suara. Maka dari itulah peran operator sangat dibutuhkan dalam pertunjukan Tayub, karena dinilai sangat mendukung dalam suatu pertunjukan.

\subsubsection{Karang Taruna}

Karang taruna adalah sekelompok orang yang bertugas melayani tamu undangan dan melayani pelaku seni. Karang taruna bekerja bersama dan bergotong-royong membantu orang yang punya hajad. Karang taruna bekerja 
secara bergantian dari hajadan satu ke hajad yang lain dan tidak meminta imbalan, hanya saja karang taruna mendapatkan upah seikhlasnya dari penanggap.

Karang taruna bekerja dengan cara membawa makanan atau minuman dan menyuguhkan untuk tamu undangan. Karang taruna juga bekerja mengambil gelas dan piring yang kotor setelah digunakan oleh orang-orang yang telah slesai menggunakannya. Biasanya karang taruna mendapatkan upah dari yang punya hajat seikhlasnya lalu upah tersebut dikumpulkan menjadi uang kas dan akan digunakan kembali sebagai kepentingan karang taruna untuk membuat seragam. Dalam pertunjukan Tayub, karang taruna tidak bekerja sendiri, karang taruna telah dibantu oleh orang-orang yang bertanggung jawab didapur. Orang-orang tersebut terdiri dari tukang masak, tukang cuci piring, tukang menyiapkan makanan dan tukang menyiapkan minuman.

Mengingat lokasi Desa Bedingin yang jauh dari jangkauan kota, maka tidak disediakan makanan yang berupa prasmanan dan beraneka masakan. Masyarakat Desa Bedingin hanya menyediakan 1 macam makanan, misalkan hanya soto, rawon atau lodeh. maka dari itu semua urusan makanan dan minuman akan dilayani oleh karang taruna. Keterlibatan karang taruna dalam pertunjukan Tayub ini sangatlah membantu untuk semua penikmat pertunjukan Tayub.

Kesimpulannya bahwa peran masyarakat yang berada di dalam pertunjukan Tayub sangatlah dibutuhkan. Peran masyarakat sebagai karang taruna dan juru masak bertugas membantu melayani tamu undangan, pemanin, kesenian Tayub dan penonton. Karena sebuah acara tidak akan berjalan lancar tanpa adanya dukungan dan bantuan dari masyarakat. 


\section{BAB V}

\section{PENUTUP}

\subsection{Simpulan}

Berdasarkan permasalah yang telah ditulis peneliti bagaimana bentuk kesenian Tayub dan bagaimana peran masyarakat terhadap kesenian Tayub maka dapat ditarik kesimpulan bahwa peran masyarakat pada pertunjukan Tayub di Desa Bedingin Kecamatan Todanan Kabupaten Blora pada dasarnya Tayub merupakan aktivitas bersifat kolektif yang melibatkan seluruh komponen masyarakat, baik seniman pelaku, penonton, tamu undangan maupun pedagang.

Bentuk pertunjukan Tayub meliputi pembukaan, inti dan penutup yang terdiri dari pemain, iringan, tata rias, tata busana dan tempat pentas. Penyajian Tayub diawali klenengan untuk mengundang masyarakat,agar mendatangi pusat sumber suara, para joged menari gambyong. Setelah gambyong pranatacara mempersilahkan penanggap atau petinggi desa untuk mengawali menari bersama joged dilanjutkan inti dengan Tayuban. Pada pertunjukan penutup, ditandai dengan gendhing langgam pamitan menandakan acara telah selesai.

Peran masyarakat Desa Bedingin dalam pertunjukan Tayub sebagai penonton, pedagang, tamu undangan dan pengibing. Penonton berperan sebagai seseorang atau berkelompok yang menyaksikan dansebagai penikmat dalam pertunjukan Tayub. Pengibing berperan dalam pertunjukan Tayub yaitu sebagai orang yang ikut berpartisipasi dalam kegiatan menari bersama joged. Pedagang berperan dengan berkelompok menyerupai pasar tiban yang merupakan tempat keramaian dan pusat jajanan yang digelardalam pertunjukan Tayub. Peran tamu 
undangan yaitu dapat sebagai pengibing, penonton dan penikmat, tamu undangan merupakan teman atau kerabat yang mendapatkan undangan dalam pertunjukan Tayub. Peran masyarakat sangat mendukung dan penting, karena tanpa adanya dukungan masyarakat pertunjukan Tayub tidak akan berjalan lancar.

\subsection{Saran}

\subsubsection{Pemerintahan Desa Bedingin}

Pemerintah Desa Bedingin hendaknya menyediakan wadah bagi senimanseniman yang ada di Desa Bedingin agar lebih dapat mengembangkan bakat terutama pada kesenian Tayub.

\subsubsection{Dinas Pariwisata dan Kebudayaan}

Dinas pariwisata untuk terus memperhatikan keberadaan kesenian terutama kesenian kerakyatan Tayub. Menjaga dan mengembangkan dengan memberikan bantuan sarana dan prasarana pendukung kesenian Tayub serta didirikannya sanggar seni tari yang didalamnya terdapat kesenian Tayub, sehingga ketika ada acara hajatan tidak perlu mendatangkan atau menyewa kesenian lain sehingga lebih ringan menggunakan swasembada masyarakat desa sendiri, diharapkan pula dapat mempromosikan kesenian Tayub. Lembaga pendidikan untuk dapat menyelenggarakan kegiatan kesenian seperti kesenian Tayub.

\subsubsection{Bagi Departemen Pendidikan dan kebudayaan Kabupaten Blora}

Bagi Departeman Pendidikan dan kebudayaan Kabupaten Blora hasil penelitian ini dapat menambah sumber informasi sehingga dapat dijadikan dasar pertimbangan dalam menjaga kelestarian seni pertunjukan Tayub. 


\section{REFERENCES}

Arikunto, Suharsimi.1998. Prosedur Penelitian Suatu Pendekatan Praktik. Jakarta: Rineka Cipta.

Bastomi, Suwaji. 1992. Wawasan Seni. IKIP Semarang Press

Cahya, nur. 2013. Dalam Skripsi Dengan Judul Penyajian Tayub Dalam Upacara Apitan di Desa Tanggel Kecamatan Winong Kabupaten Pati.

Cahyono, Agus. 2002. Eksistensi Tayub dan Sistem Transmisinya. Yogyakarta: Yayasan Lentera Budaya.

Departemen Pendidikan dan Kebudayaan, 1986. Ensiklopedi Tari Indonesia Seri $P-T$ Jakarta: Departemen Pendidikan dan Kebudayaan, Proyek Inventarisasi dan Dokumentasi Kebudayaan Daerah.

Umami, afriza. 2013. Skripsi Dengan Judul Peran Pengibing Dalam Pertunjukan. Tayub di Desa Kemiri Kecamatan Jepon. Kabupaten Blora

Greetz, cliffrord. 1983. Abangan, Santri, Priyayi, dalam Masyarakat Jawa. Jakarta: PT. Pustaka Jaya

Hadi, Y Sumadio. 1996. Aspek-Aspek Dasar Koreografi Kelompok. Yogyakarta: Manthili

Ambarwangi, S., \& Suharto, S. (2014). REOG AS MEANS OF STUDENTS' APPRECIATION AND CREATION IN ARTS AND CULTURE BASED ON THE LOCAL WISDOM. Harmonia: Journal Of Arts Research And Education, 14(1), 37-45. doi:http://dx.doi.org/10.15294/harmonia.v14i1.2789

Ambarwangi, S., \& Suharto, S. (2013). PENDIDIKAN MULTIKULTURAL DI SEKOLAH MELALUI PENDIDIKAN SENI TRADISI. Harmonia: Journal Of Arts Research And Education, 13(1). doi:http://dx.doi.org/10.15294/harmonia.v13i1.2535

Subandi. (2011). Lakon Anoman Duta Garap Padat: Sebuah Penelitian Singkat (The Condensed Creativity of Anoman Duta : A Short Study). Harmonia: Journal Of Arts Research And Education, 6(3). doi:http://dx.doi.org/10.15294/harmonia.v6i3.813

Suharto, S., \& Aesijah, S. (2014). THE LESUNG MUSIC IN THE VILLAGE OF LEDOK BLORA REGENCY. Harmonia: Journal Of Arts Research And Education, 14(1), 65-71. doi:http://dx.doi.org/10.15294/harmonia.v14i1.285 
Suharto, S. (2011). Refleksi Teori Kritik Seni Holistik : sebuah Pendekatan Alternatif dalam Penelitian Kualitatif bagi Mahasiswa Seni (Reflection on Art Criticism and Holistic Art Criticism : an Alternative Approach of Qualitative Research for Art Students). Harmonia: Journal Of Arts Research And Education, 8(1). doi:http://dx.doi.org/10.15294/harmonia.v8i1.803

Putra, B. (2013). PENGEMBANGAN MODEL KONSERVASI KESENIAN LOKAL SEBAGAI KEMASAN SENI WISATA DI KABUPATEN SEMARANG. Harmonia: Journal Of Arts Research And Education, 12(2). doi:http://dx.doi.org/10.15294/harmonia.v12i2.2525

Irianto, A. (2016). The Development of Jathilan Performance as an Adaptive Strategy Used by Javanese Farmers. Harmonia: Journal Of Arts Research And Education, 16(1), 38-48. doi:http://dx.doi.org/10.15294/harmonia.v16i1.5213

Hapsari, L. (2014). FUNGSI TOPENG IRENG DI KURAHAN KABUPATEN MAGELANG. Harmonia: Journal Of Arts Research And Education, 13(2). doi:http://dx.doi.org/10.15294/harmonia.v13i2.2780

Ispahani, V. (2012). APRESIASI SEBAGAI SALAH SATU PENDEKATAN DALAM PEMBELAJARAN SENI TARI DI SMP. Harmonia: Journal Of Arts Research And Education, 11(1). doi:http://dx.doi.org/10.15294/harmonia.v11i1.2070

Budiarti, M. (2011). MENGUBAHÂ CITRA LENGGER MENJADIÂA MEDIA EKSPRESIÂA ESTETIS (To Change the Image of Lengger Into Esthetic $\hat{A}$ Medium of Expression). Harmonia: Journal Of Arts Research And Education, 4(2). doi:http://dx.doi.org/10.15294/harmonia.v4i2.708

Malarsih, M., \& Herlinah, H. (2014). Creativity Education Model through Dance Creation for Students of Junior High School. Harmonia: Journal Of Arts Research And Education, 14(2), 147-157. doi:http://dx.doi.org/10.15294/harmonia.v14i2.3296

Darmasti. "TARI SESAJI PANGENTAS BILAHI SUDRA TINGAL." Harmonia: Journal of Arts Research and Education [Online], 12.2 (2012): n. pag. Web. 24 Sep. 2017

Tarwiyah, T. (2011). PELESTARIAN BUDAYA BETAWI PERMAINAN ANAK CICI PUTRI DAN ULABANG/ WAK WAK GUNG : KAJIAN KANDUNGAN KECERDASAN JAMAK. Harmonia: Journal Of Arts Research And Education, 10(1). doi:http://dx.doi.org/10.15294/harmonia.v10i1.51

Tarwiyah, T. (2011). ANALISIS NILAI-NILAI PENDIDIKAN DALAM LAGULAGU DAERAH BETAWI (An Analysis of Educational Values in Songs of the BetawiArea). Harmonia: Journal Of Arts Research And Education, 5(1). doi:http://dx.doi.org/10.15294/harmonia.v5i1.831 
Suryani, S. (2014). Tayub as a Symbolic Interaction Medium in Sedekah Bumi Ritual in Pati Regency. Harmonia: Journal Of Arts Research And Education, $\quad$ 14(2), doi:http://dx.doi.org/10.15294/harmonia.v14i2.3291

97-106.

Widodo, B. (2011). SLENDRO PELOG: SUATU KETERASINGAN DI DUNIA ANAK. Harmonia: Journal Of Arts Research And Education, 1(1). doi:http://dx.doi.org/10.15294/harmonia.v1i1.837

Widodo, W. (2011). Nuansa Laras Diatonik dalam Macapat Semarangan (Diatonic Scale Atmosphere in Semarang Style Macapat).. Harmonia: Journal Of Arts Research And Education, 7(1). doi:http://dx.doi.org/10.15294/harmonia.v7i1.751

Wiyoso, J. (2011). PENGARUH DIFUSI DALAM BIDANG MUSIK TEHADAP KARAWITAN (The Influence Diffusion of Music to Karawitan). Harmonia: Journal Of Arts Research And Education, 3(2). doi:http://dx.doi.org/10.15294/harmonia.v3i2.687

Wiyoso, J. (2017). Puppet Visual Adaptation on Playing Cards as Educational Media. Harmonia: Journal Of Arts Research And Education, 16(2), 182-191. doi:http://dx.doi.org/10.15294/harmonia.v16i2.5816

Kusumastuti, E. (2011). PENDIDIKAN SENI TARI PADA ANAK USIA DINI DI TAMAN KANAK-KANAK TADIKA PURI CABANG ERLANGGA SEMARANG SEBAGAI PROSES ALIH BUDAYA. Harmonia: Journal Of Arts Research And Education, 5(1). doi:http://dx.doi.org/10.15294/harmonia.v5i1.826

Pratjichno, B. (2011). Pornografi dalam Dunia Seni Tari (Pornography in Dance World). Harmonia: Journal Of Arts Research And Education, 7(2). doi:http://dx.doi.org/10.15294/harmonia.v7i2.769

Haryono, S. (2011). DANGDUT DAN EKSPLOITASI SEKS PEREMPUAN (Dangdut and Woman Sex Exploitation). Harmonia: Journal Of Arts Research And Education, 3(2). doi:http://dx.doi.org/10.15294/harmonia.v3i2.688

Budiarti, M. (2011). MENGUBAH CITRA LENGGER MENJADI MEDIA EKSPRESI ESTETIS (To Change the Image of Lengger Into Esthetic Medium of Expression). Harmonia: Journal Of Arts Research And Education, 4(2). doi:http://dx.doi.org/10.15294/harmonia.v4i2.708

Hidajat, R. (2014). The Popularity of Waranggana Tayub Malang through Body Exploitation. Harmonia: Journal Of Arts Research And Education, 14(2), 72-77. doi:http://dx.doi.org/10.15294/harmonia.v14i2.3288

Noordiana, N., Juwariyah, A., \& Inda, F. (2017). The Impact of Tayub Exploitation on The Tradition and Life of Javanese Society. Harmonia: Journal Of Arts Research And Education, 16(2), 133-142. doi:http://dx.doi.org/10.15294/harmonia.v16i2.7514 
Pigeaud, Kerajaan-Kerajaan Islam di Jawa (Peralihan dari Majapahit ke Mataram). Terj. Gratifitipers dan KITLV Kejayaan kerajaan Demak pada dasawarsa terakhir abad ke-15 dan paro pertama abad ke-16.

Jazuli, M. 1994. Telaah Teoritis Seni Tari. Semarang: IKIP Semarang Press. 2008. Paradigma Seni Pertunjukan. Yogyakarta: yayasan lentera budaya.

Lindsay, 1991. Klasik, Kitsch, Kontenporer: Sebuah Studi Tentang Seni Pertunjukan Jawa. Terj. Nin Bakdi Sumanto Yogyakarta: Gadjah Mada University Press.

Kayam, 1981. Seni Tradisi Masyarakat. Jakarta: Balai Pustaka.

Rohana, 1988. dalam Amengkunegara. Serat Cethini, Trans. Kamajaya Yogyakarta: Yayasan Cethini.

Koenjaraningrat. 1986. Pengantar Ilmu Antropologi. Jakarta: Akara Baru.

Marinis, Marco. 1993.The Semiotics Of Performance. Terj. Aine O'heal Bloomington And Indianapolis: Indiana University Press.

Moeliono, 1991. Kamus Umum Bahasa Indonesia. Jakarta: Balai Pustaka.

Moleong, Lexy. 2001. Metodologi Penelitian Kualitatif. Bandung: PT. Remaja Rodakarya.

Zoetmulder. 1063;1997. bekerjasama dengan Robson. Kamus Jawa KunaIndonesia, Terj. Darusuprapto Dan Sumarti Suprayitno Jakarta: PT Gramedia Pustaka Utama.

Purwodarminto. 2002. Kamus Besar Bahasa Indonesia. Departemen Pendidikan dan Kebuyaan. Balai Pustaka: Jakarta.

Poerbatjaraka. 1957. Kapustakan Djawi Jakarta: Penerbit Djambatan.

Wirjosuparto. 85;1968. Kakawin Bharatayuda Jakarta: Penerbit Bharata.

Redfield, Robert. 81;1982. Masyarakat, Petani dan Kebudayaan. Terj. Daniel Dhakidae Jakarta: Cv Rajawali.

Suharto, Ben. 12;1999 Tayub: Pertunjukan dan Ritus Kesuburan Bandung: Masyarakat Seni Pertunjukan Indonesia. 
Soedarsono, 2001. Metodologi Penelitian Seni Pertunjukan Dan Seni Rupa. Cetakan Kedua Bandung: Masyarakat Seni Pertunjukan Indonesia.

Soedarsono, 2002 Seni Pertunjukan Indonesia Di Era Globalisasi. Cetakan ketiga. Yogyakarta: Gadjah mada university press

Soekanto. 1990. Sosiologi Suatu Pengantar. Jakarta: Rajawali

Syah Sinaga, Syahrul. 2001. Akulturasi Kesenian Rebana. Semarang Harmonia Vol.2 No. 3/September-Desember. Semarang: UNNES.

Thowok, Nini. D. 2012. Stage Make-Up By Nini Thowok. Jakarta: Gramedia Pustaka Utama.

Widyastutieningrum, Sri Rochana. 2009. "Penari Tayub Primadona Dari Desa Todanan Blora" dalam buku pesona perempuan dalam sastra dan seni pertunjukan. Bandung: sunan Ambu STSI Press Surakarta.

- 2004. Sejarah Tari Gambyong Seni Rakyat Menuju Istana Surakarta: Citra Etnika.

—2007. "Penari Perempuan Dalam Tayub Di Blora Jawa Tengah: sebuah pendekatan etnokoreologi." Surakata: ISI Press Surakarta.

-2007. Tayub di Blora Jawa Tengah Pertunjukan Ritual Kerakyatan. Surakarta: ISI Press Surakarta.

Widjanarko, 2004. Peran masyarakat dalam pengelolaan lingkungan hidup di kabupaten kudus laporan penelitian. Kudus: puslitbang UMK-Pusat.

Winter, Ranggawarsita. 1987. Kamus Kawi-Jawa. Yogyakarta: Gadjah Mada University Press.

Yayasan Radyapustaka, 1970 Serat Sastramiruda Surakarta: Radyaustaka. 


\section{GLOSARIUM}

Beskap

Blangkon

Gendhing

Gong

Ingkung

Joged

Kempul

Kenong

Klenengan

Ketawang

Kondhe

Kondangan
: Jas model Jawa

: Sejenis topi yang dipakai laki-laki tradisi Jawa

: Lagu atau nyanyian dalam karawitan Jawa

:Instrumen gamelan Jawa yang terbuat dari

perunggu dan berpencu, untuk mengawali dan

mengkhiri gendhing dan tanda berakhirnya gatra

: Ayam sesaji upacara pembukaan

: Penari wanita atau ledhek

: Instrumen gamelan Jawaberpencu, sebagai

penanda dalam gendhing, dimainkan seperti

balungan

: Instrumen gamelan Jawa berpencu, berfungsi

menegaskan irama

: Pembukaan pertunjukan Tayub

: Salah satu bentuk gendhing dalam karawitan yang

1 gong terdiri dari 16 ketukan

: Sanggul rambut

: Do’a bersama 
Ladrang

Ledhek

Nanggap

Pambekso

Pangguyup

Pelok

Penanggap

Pengarih

Pengibing

Pranatacara

Sampur

Toyibun

Tumpeng

Wiru

Wirosuworo
: Salah satu bentuk gendhingdalam karawitan yang

1 gong terdiri dari 32 ketukan

: Penari dan penyanyi kesenian Tayub

: Mengadakan

: Orang yang menari di depan ledhek

: Orang yang menari di belakang ledhek

: Tangga nada yang menggunakan 7 nada dalam

gamelan tradisi Jawa

: Orang yang punya hajad

: Orang yang bertugas mencatat calon pengibing

: Orang yang menari bersama ledhek

: Pembawa acara pada adat Jawa

: Selendang sebagai perlengkapan tari

: Sebutan kesenian Tayub pada zaman Sunan

Kalijaga

: Nasi yang berbentuk kerucut digunakan untuk upacara dimulainya pertunjukan Tayub

: Lipatan pada tepi kain

:Penyanyi Laki-Laki 


\section{Lampiran-lampiran}


Lampiran 1

\section{PEDOMAN OBSERVASI}

1. Mengamati Desa Bedingin sebagai lokasi acara pertunjukan Tayub meliputi kondisi geografis, jumlah penduduk, pendidikan, mata pencaharian dan kesenian.

2. Pengamatan kesenian Tayub

2.1 Mengamati kesenian Tayub

2.2 Mengamati urutan kesenian Tayub

2.3 Mengamati masyarakat pelaku seni, penonton, pengibing, pedagang dan tamu undangan.

3. Pertunjukan Tayub dalam acara hajadan

3.1 Mengamati pelaku Tayub

3.2 Mengamati persiapan dalam pertunjukan Tayub

3.3 Mengamati pelaksanakan penyajian Tayub

4. Peran masyarakat dalam pertunjukan Tayub

Mengamati kegiatan masyarakat yang terlibat dalam proses pertunjukan Tayub

di Desa Bedingin Kecamatan Todanan Kabupaten Blora mulai dari awal sampai akhir acara. 
Lampiran 2

\section{PEDOMAN WAWANCARA}

1. Wawancara dengan masyarakat, Bapak Kacung Saputro sebagai pengarih:

a. Bagaimana kesenian Tayub?

b. Bagaimana sejarah kesenian Tayub?

c. Bagaimana perkembangan kesenian Tayub?

d. Bagaimana kedudukan pengarih dalam pertunjukan Tayub?

e. Adakah sesaji khusus dalam pertunjukan Tayub?

f. Apakah ada syarat-syarat khusus yang dijalankan oleh pengarih, supaya pementasan atau pertunjukan berhasil?

g. Bagaimana peran masyarakat dalam pertunjukan Tayub?

h. Bagaimana urutan sajian pertunjukan Tayub?

i. Apa yang anda lakukan jika terjadi kerusuhan dalam pertunjukan Tayub?

2. Wawancara dengan perangkat desa

a. Bagaimana letak dan kondisi geografis Desa Bedingin?

b. Bagaimana struktur penduduk di Desa Bedingin menurut mata pencaharian, pendidikan, jumlah penduduk dan kesenian?

3. Wawancara dilakukan kepada Ibu Purwaningsih sebagai joged meliputi:

a. Sejak kapan anda memulai karir dalam dunia joged?

b. Sudah berapa lama berprofesi sebagai joged?

c. Apakah profesi menjadi joged dapat membantu perekonomian keluarga?

d. Apakah ada syarat untuk menjadi joged?

e. Apakah anda mempunyai bakat menyanyi dan menari? 
f. Berapa banyak penghasilan disetiap pentas?

g. Bagaimana anda menanggapi pandangan negatif ketika dalam pertunjukan Tayub?

h. Persiapan apa saja yang dilakukan sebelum pertunjukan?

i. Apa yang dirasakan pada waktu berada diatas panggung atau diarena pertunjukan?

j. Ragam gerak apa saja yang digunakan dalam pertunjukan Tayub?

k. Jenis rias apakah yang digunakan?

1. Dari segi kostum apa saja yang digunakan?

m. Siapa saja pendukung dalam pertunjukan Tayub?

n. Peranan seperti apa yang anda tampilkan dalam pertunjukan Tayub?

4. Wawancara dengan Agil Manunggal selaku ketua paguyuban dan pengrawit
a. Apa iringan yang digunakan dalam pertunjukan Tayub?
b. Jenis gamelan apa saja yang digunakan dalam pertunjukan Tayub?
c. Adakah jenis alat yang paling mendominasi dalam pertunjukan Tayub?
d. Berapa jumlah pemain musik pengiring Tayub?
e. Gendhingapa saja yang digemari oleh para pengibing?

5. Wawancara dengan masyarakat Desa Bedingin
a. Bagaimana tanggapan anda mengenai pertunjukan Tayub di Desa Bedingin?
b. Bagaimana kesan anda mengenai adanya Tayuban?
c. Keuntungan dan manfaat apa saja yang diperoleh jika menampilkan Tayuban?

d. Peran apa yang anda lakukan dalam pertunjukan Tayub? 
Lampiran 3

IDENTITAS PENULIS

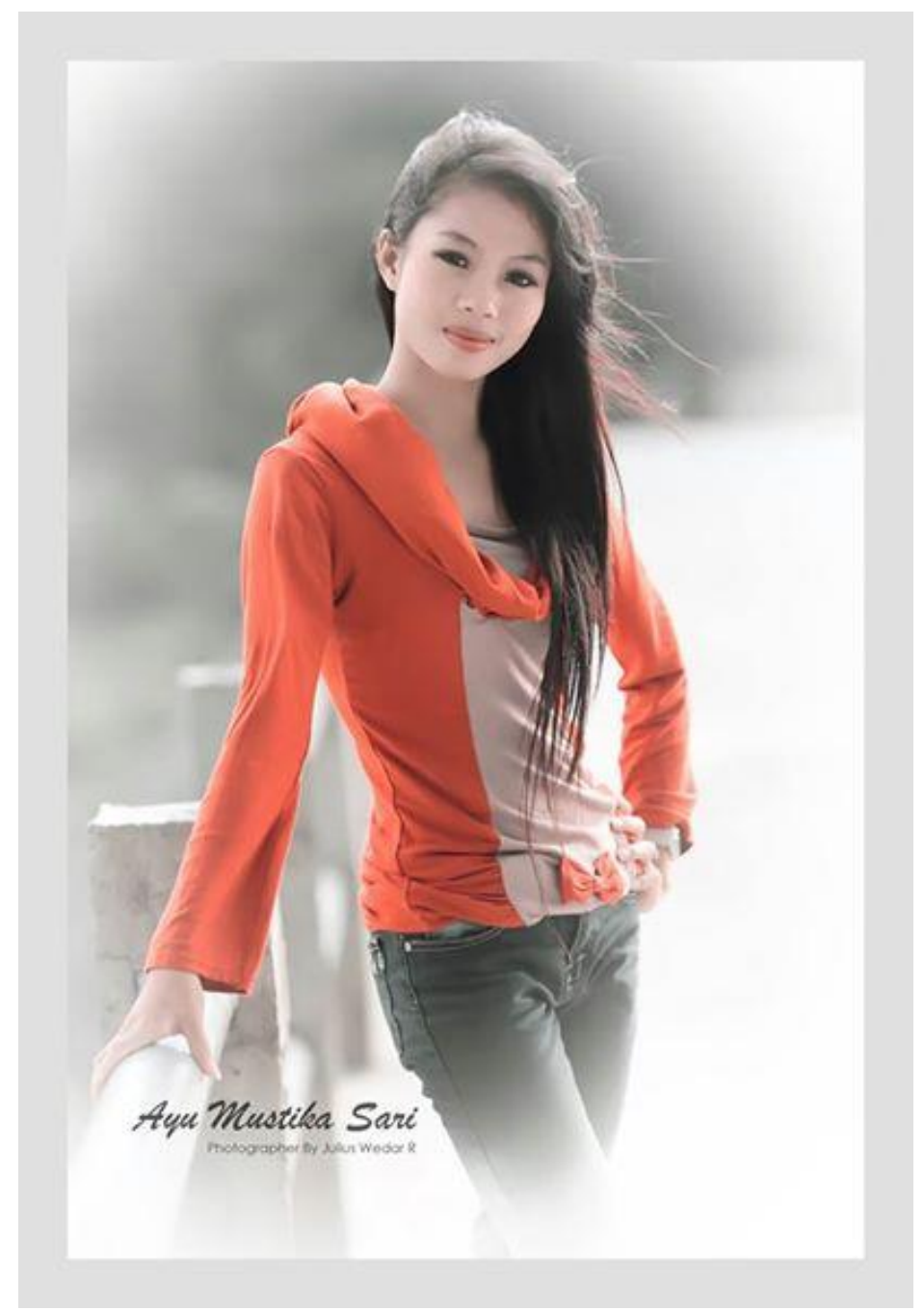

Nama

: Ayu Mustika Sari

TTL

: Pati,11 Maret 1992

Alamat

: RT 06/RW 02 Ds. Bedingin Kec. Todanan Kab. Blora

Agama

: Islam

Golongan Darah

: $\mathrm{AB}$

Status

: Belum Kawin 


\section{Lampiran 4}

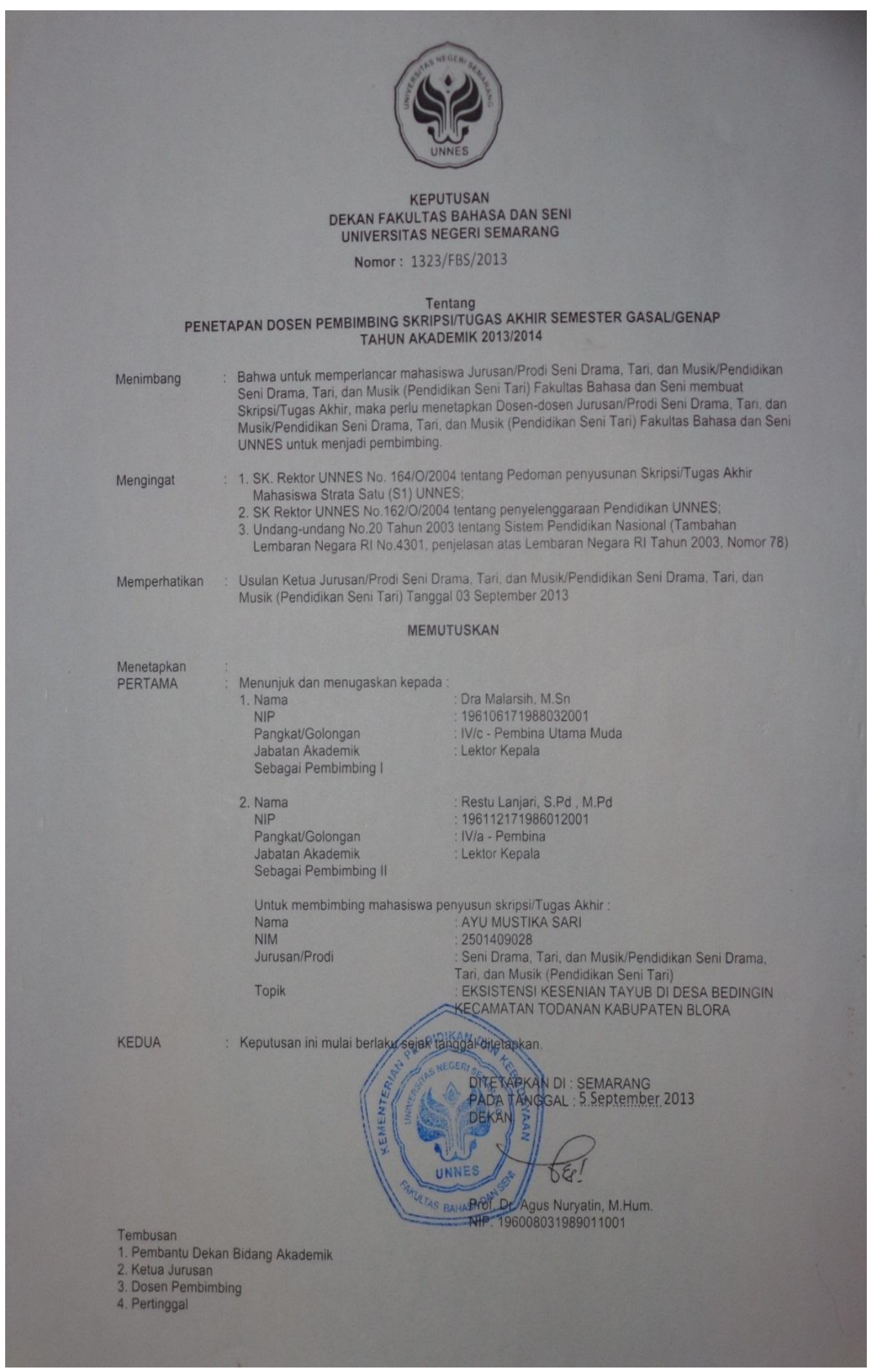




\section{Lampiran 5}

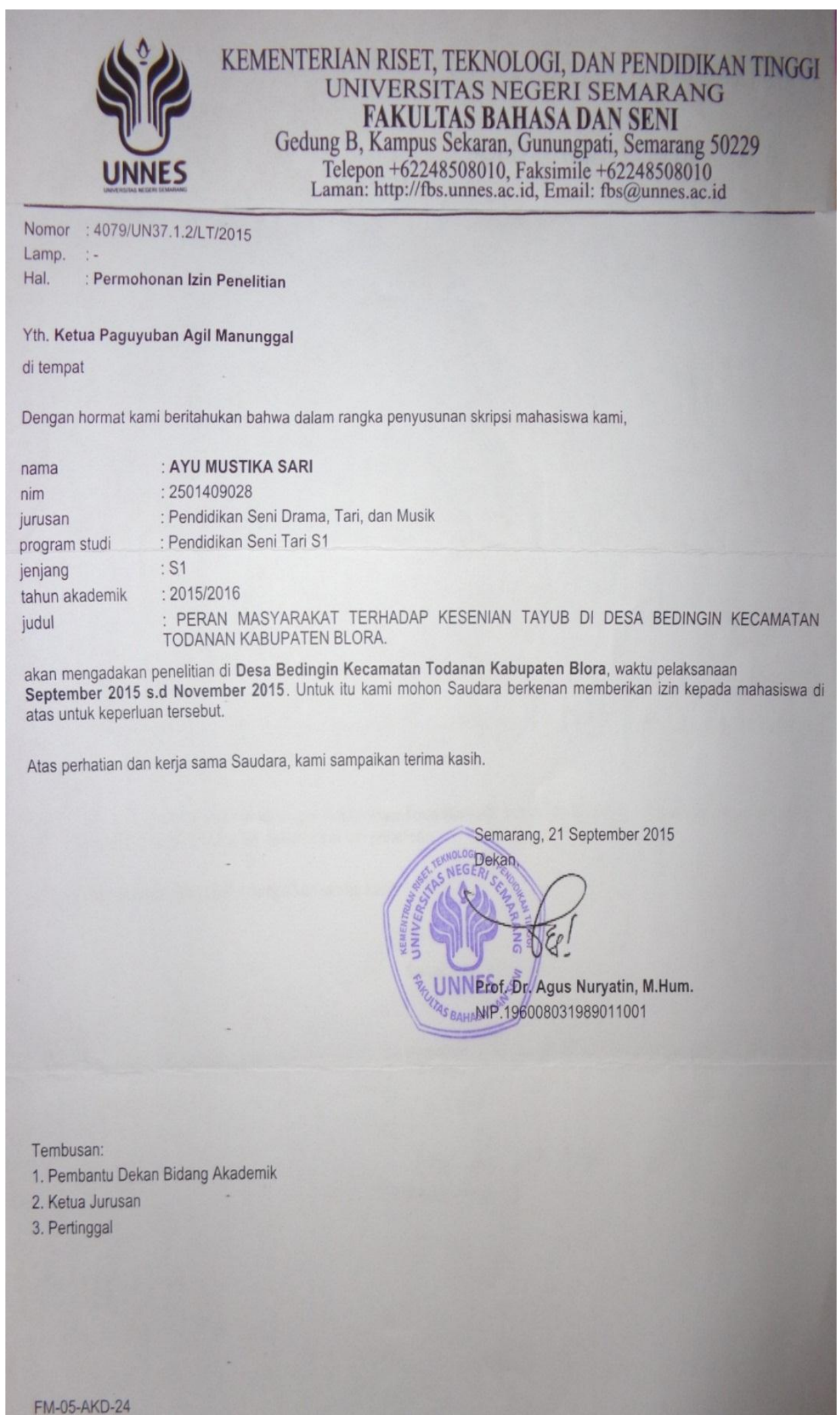




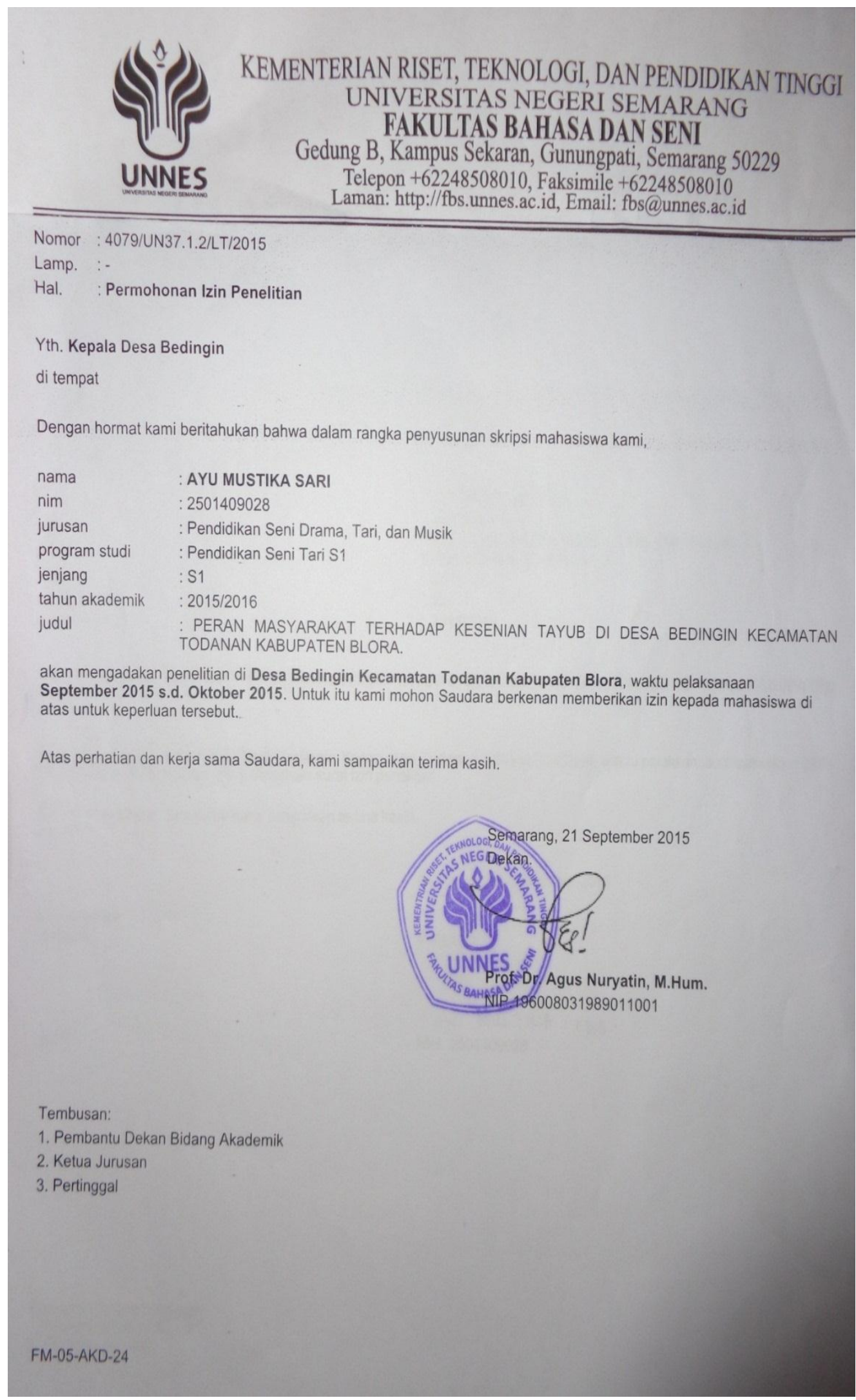




\section{Lampiran 6}

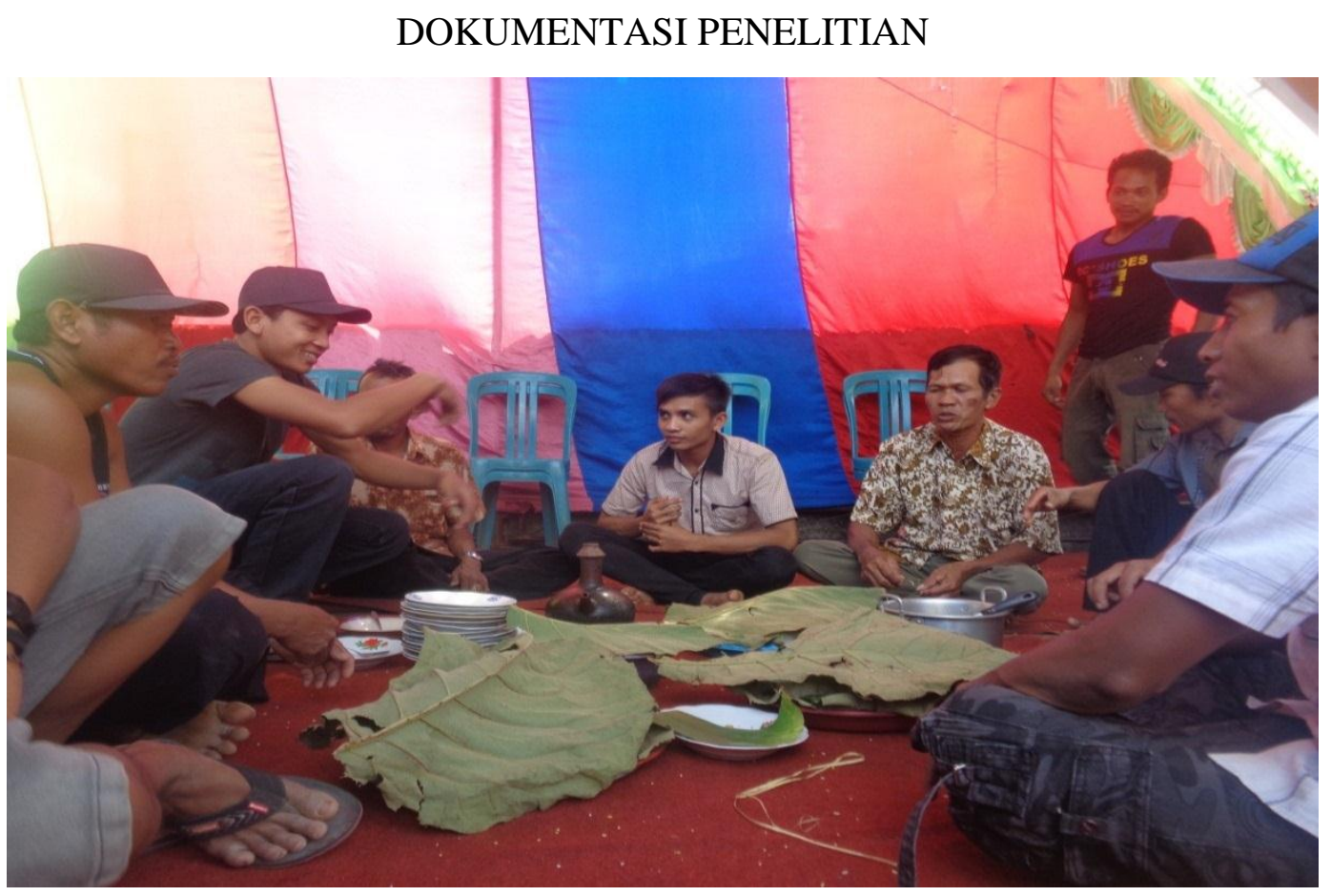

Foto 1 : Kondangan

(Dokumentasi Ayu, 2015)

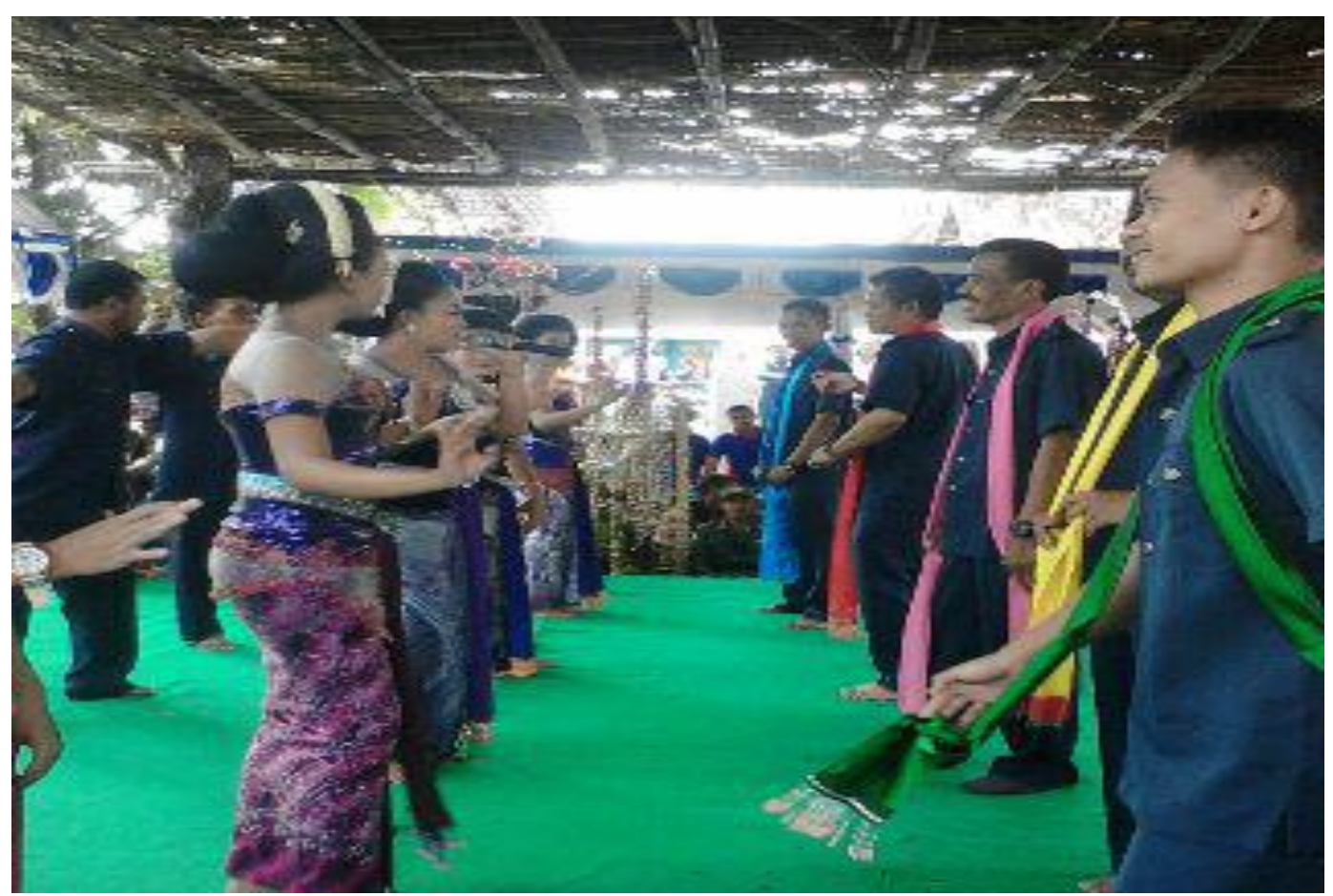

Foto 2 : Tayuban

(Dokumentasi Ayu, 2015) 


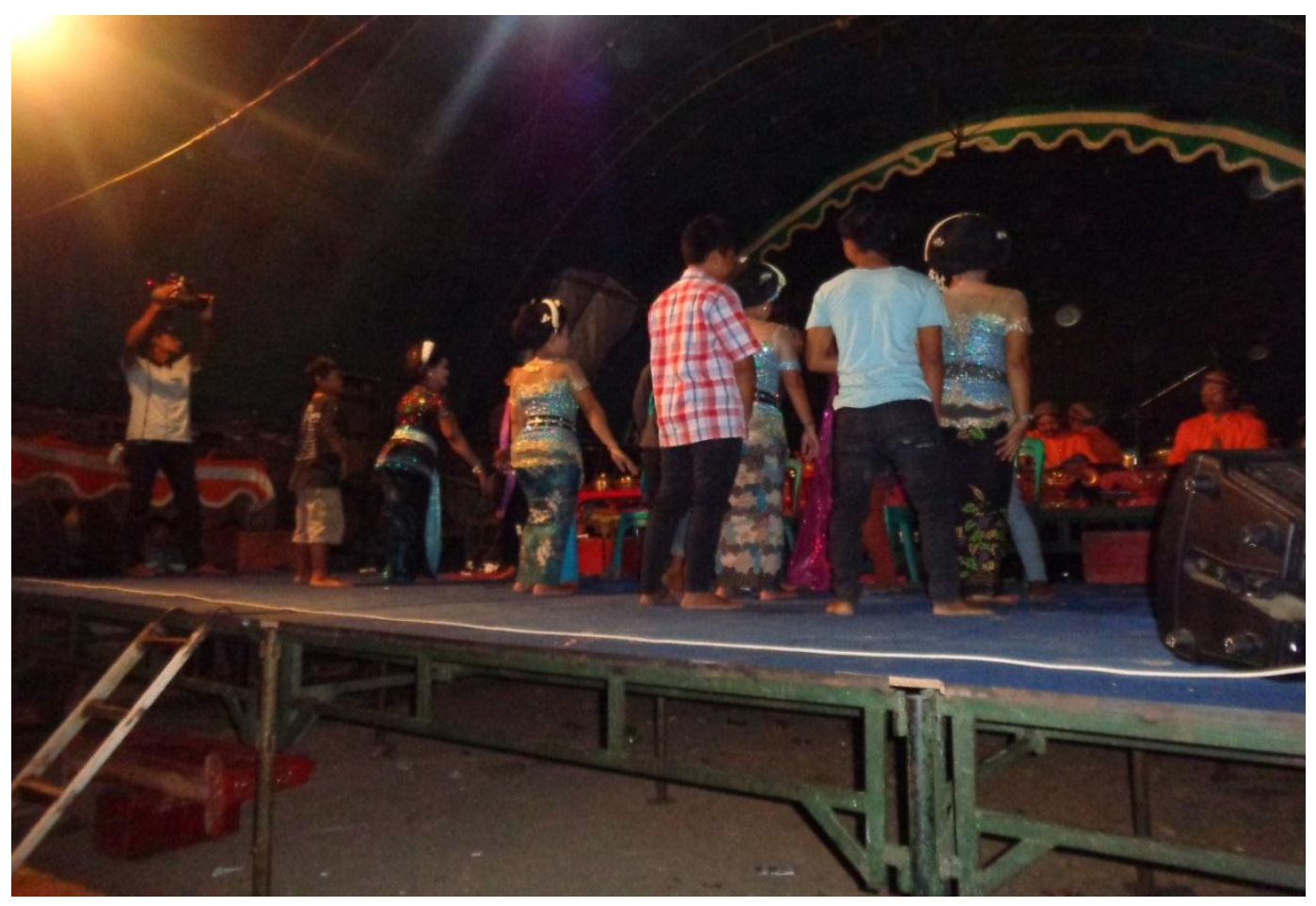

Foto 3 : Tayuban yang dilakukakan oleh anak-anak (dari sisi belakang)

(Dokumentasi Ayu, 2015)

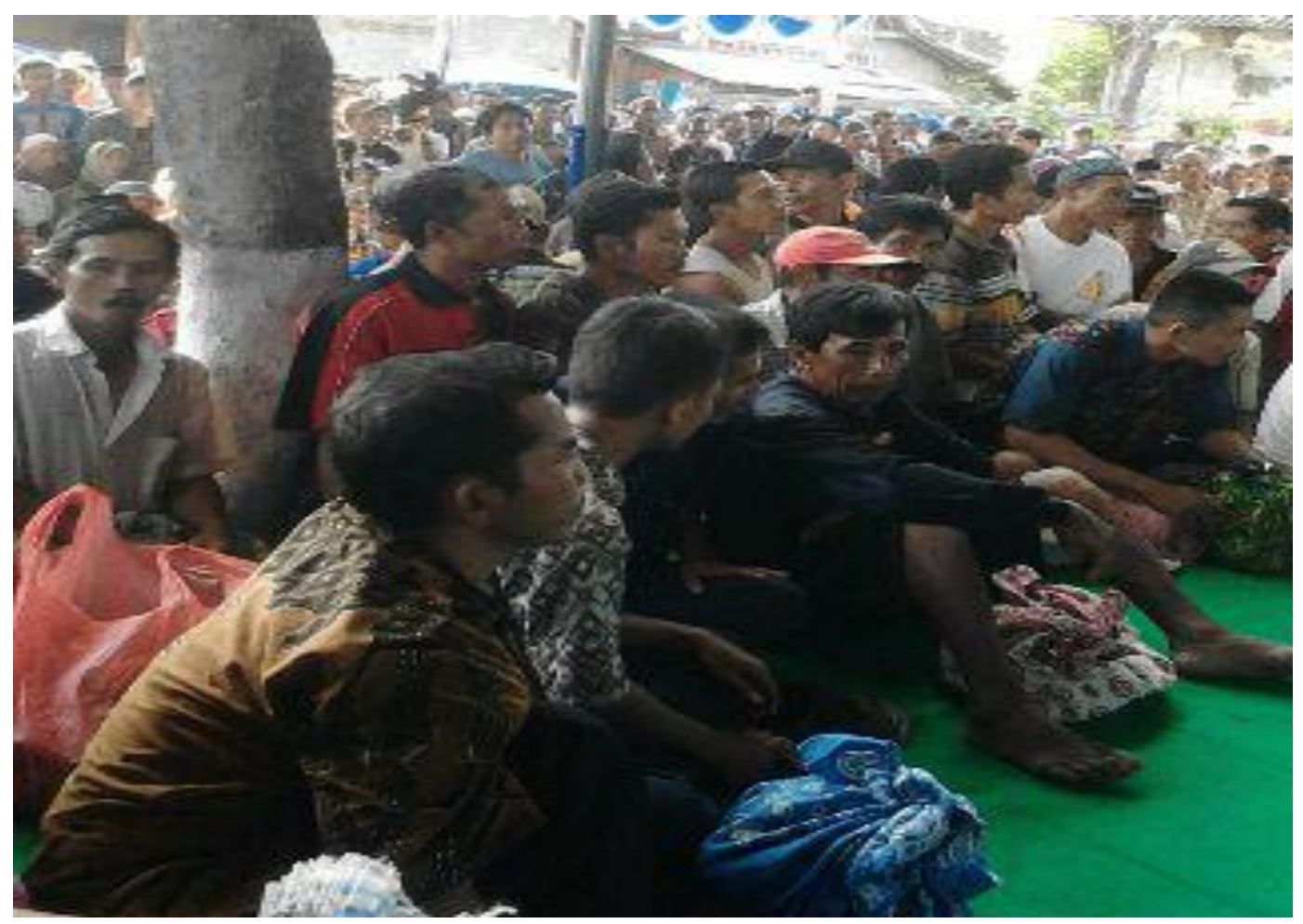

Foto 4 : Penonton Tayub dalam acara bersih desa

(Dokumentasi Ayu, 2015) 


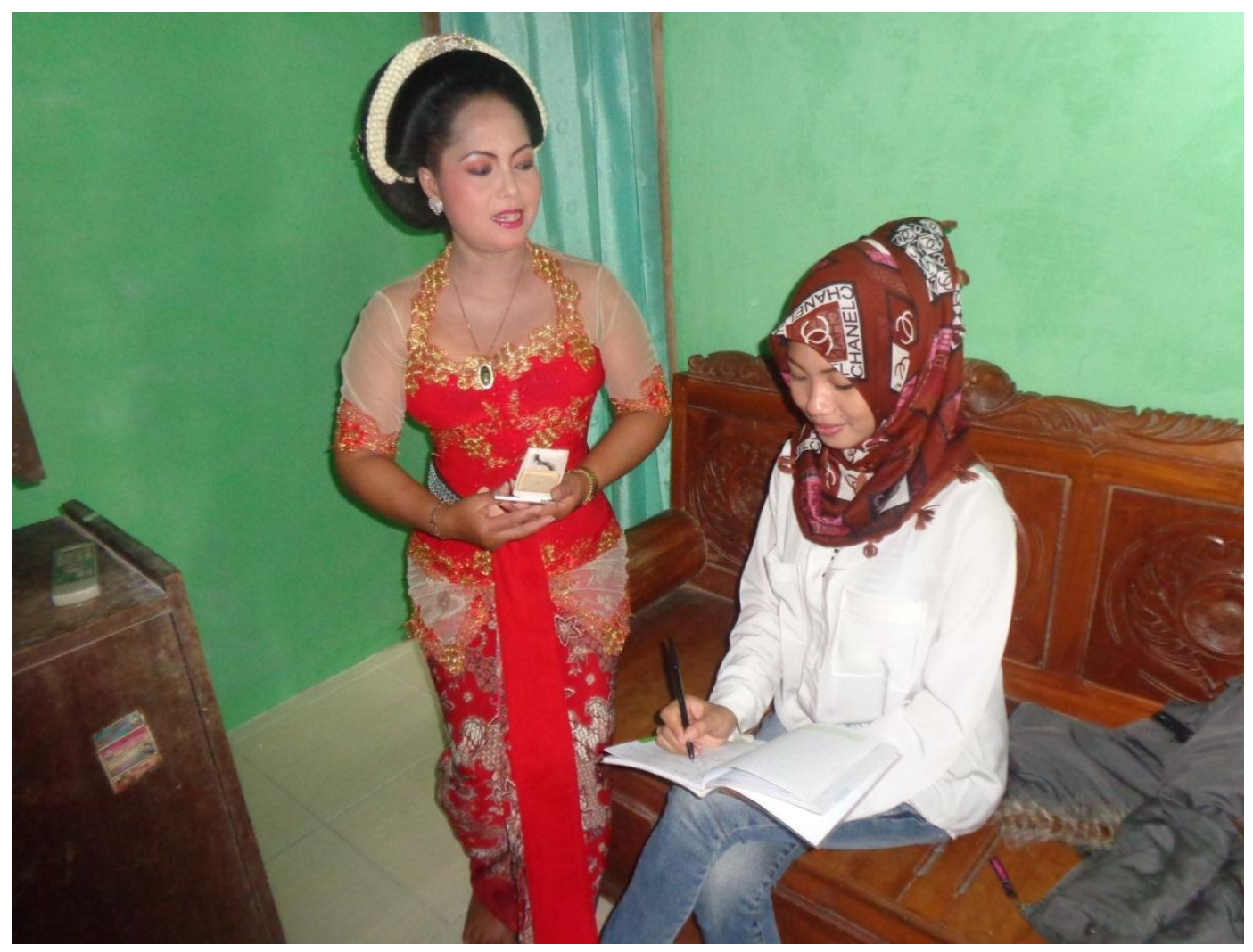

Foto 5 : Wawancara Dengan Ibu Purwaningsih

(Dokumentasi Ayu, 2015)

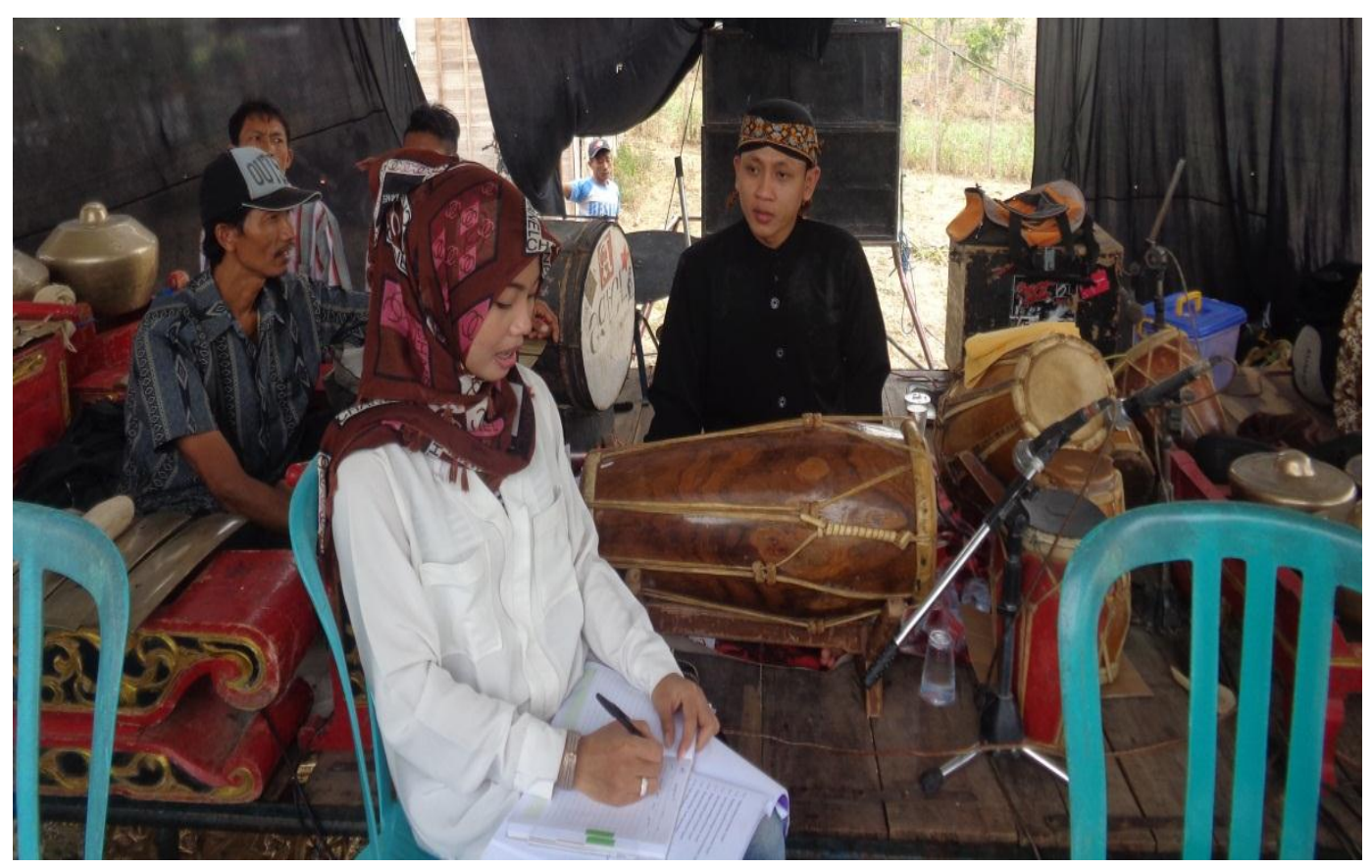

Foto 6 : Wawancara Dengan Agil

(Dokumentasi Ayu, 2015) 


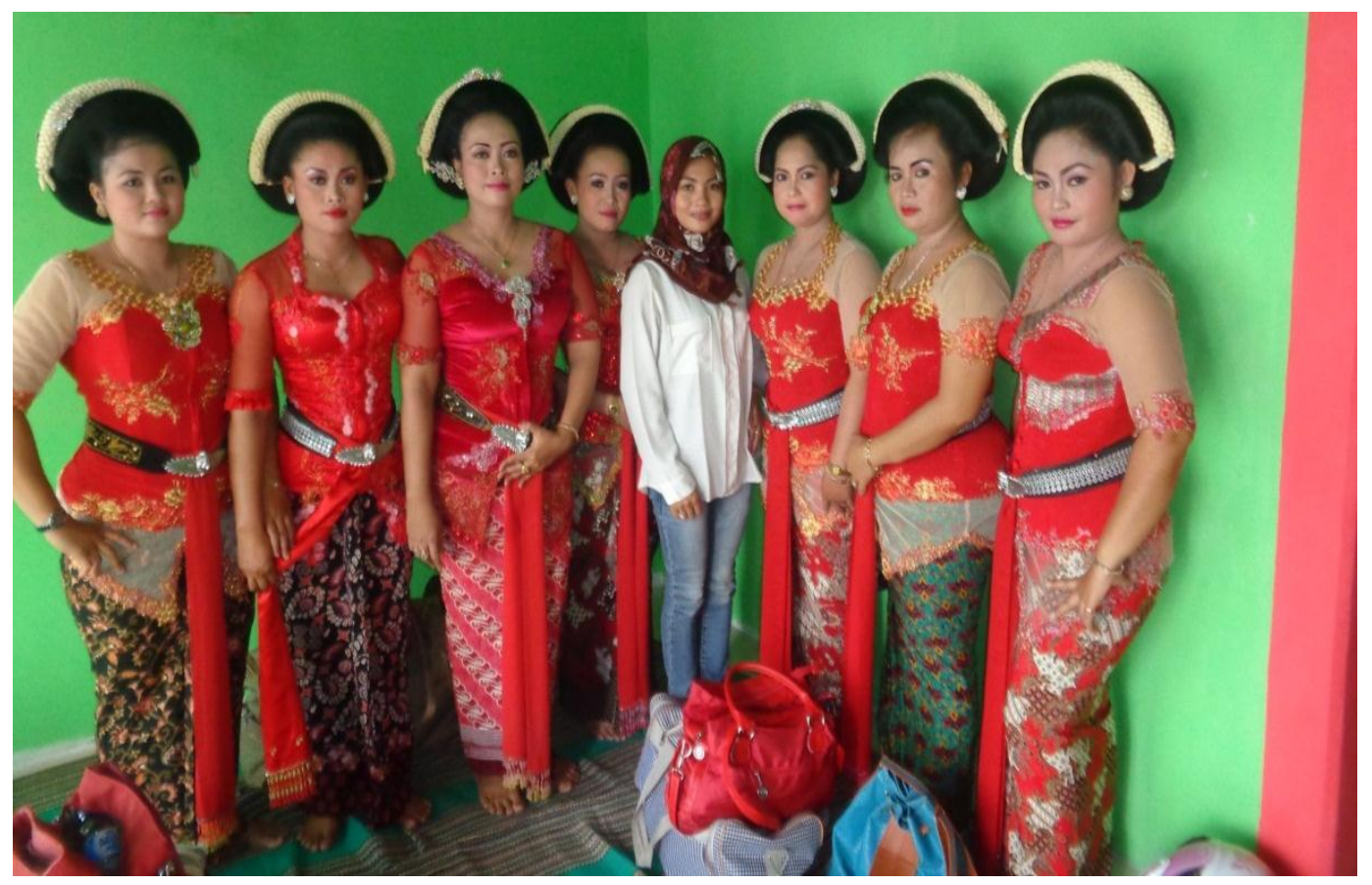

Foto 7 : Penari Tayub atau Joged

(Dokumentasi Ayu, 2015)

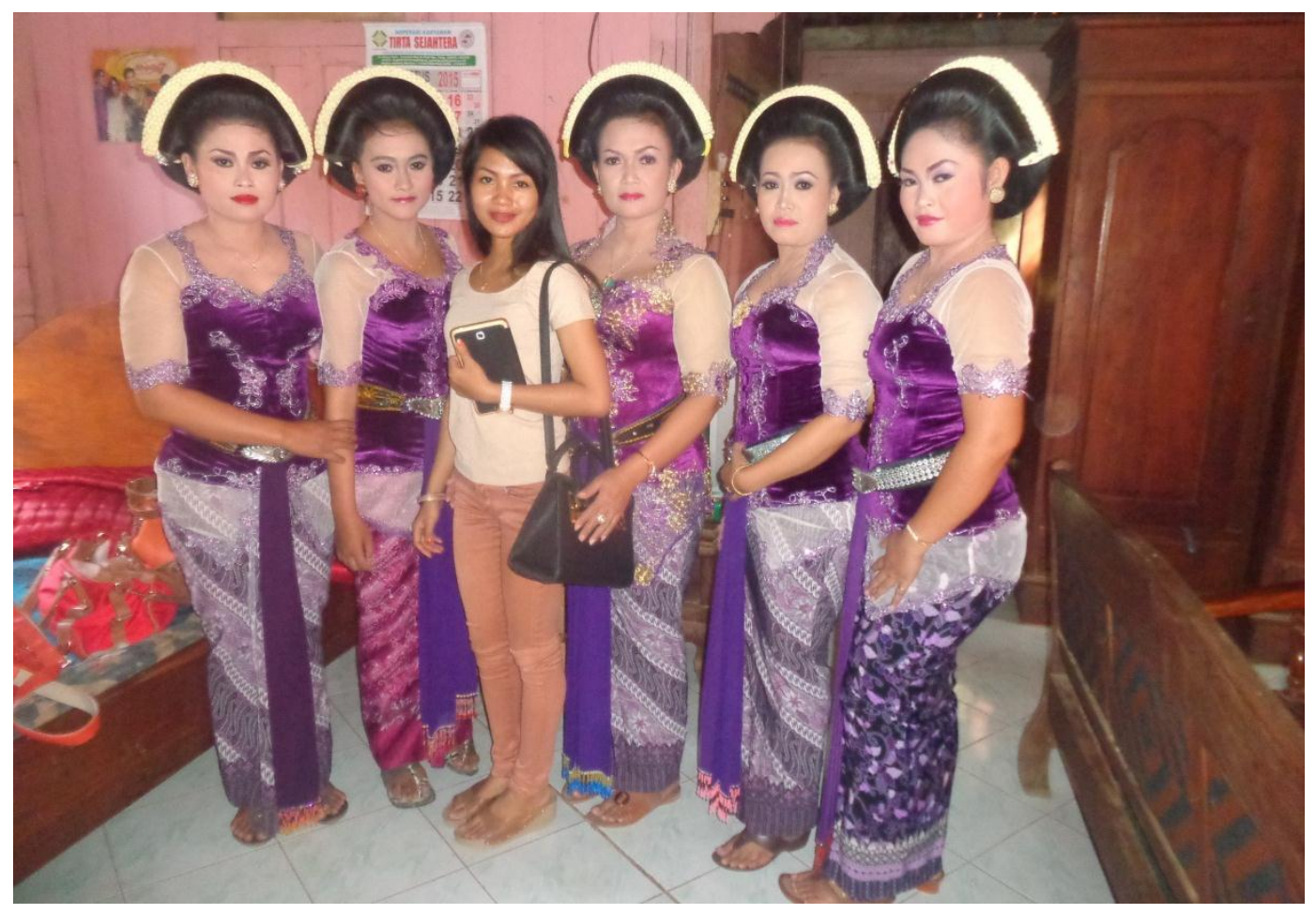

Foto 8 : Penari Tayub

(Dokumentasi Ayu, 2015) 


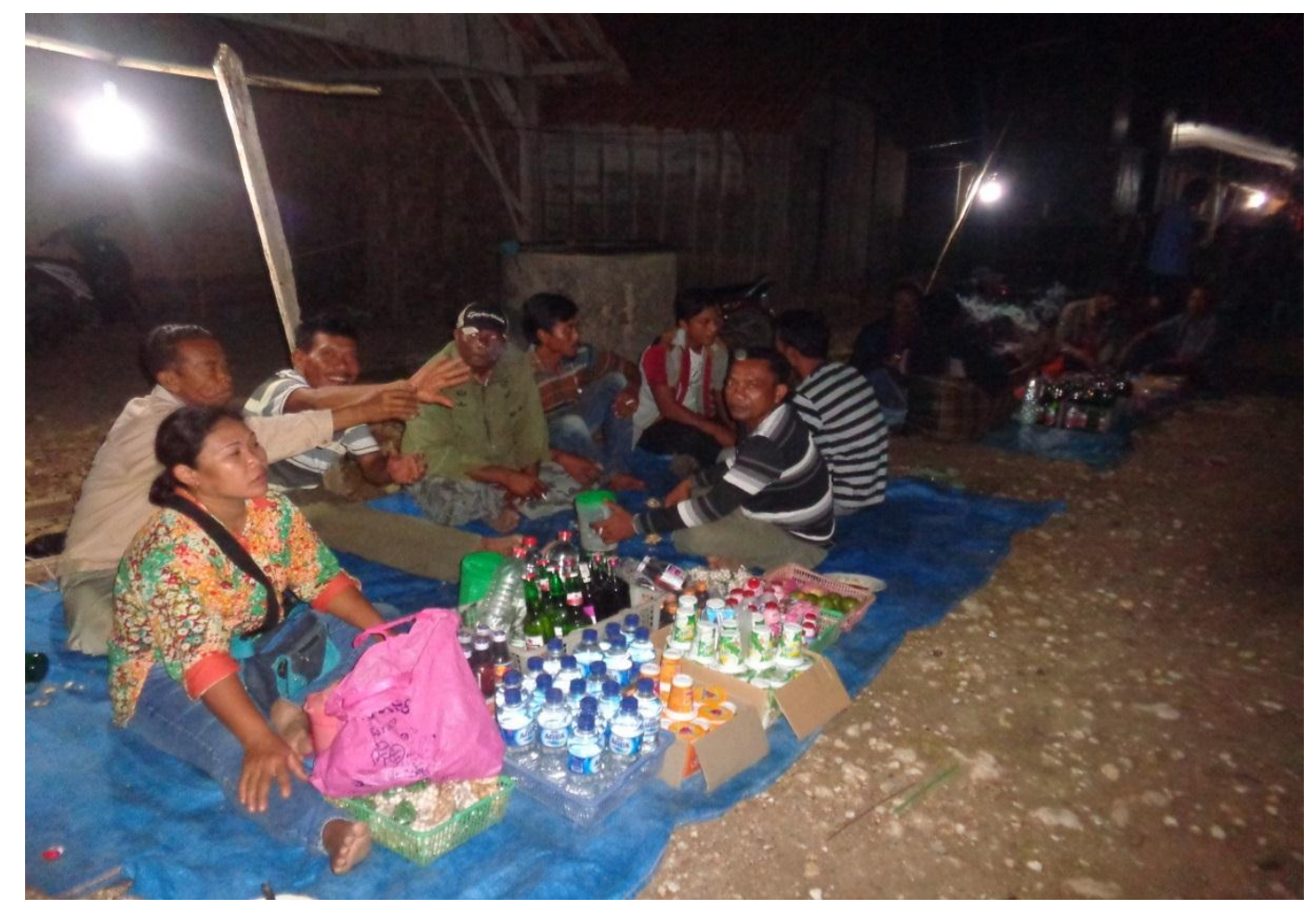

Foto 9 : Pedagang Minuman Keras

(Dokumentasi Ayu, 2015)

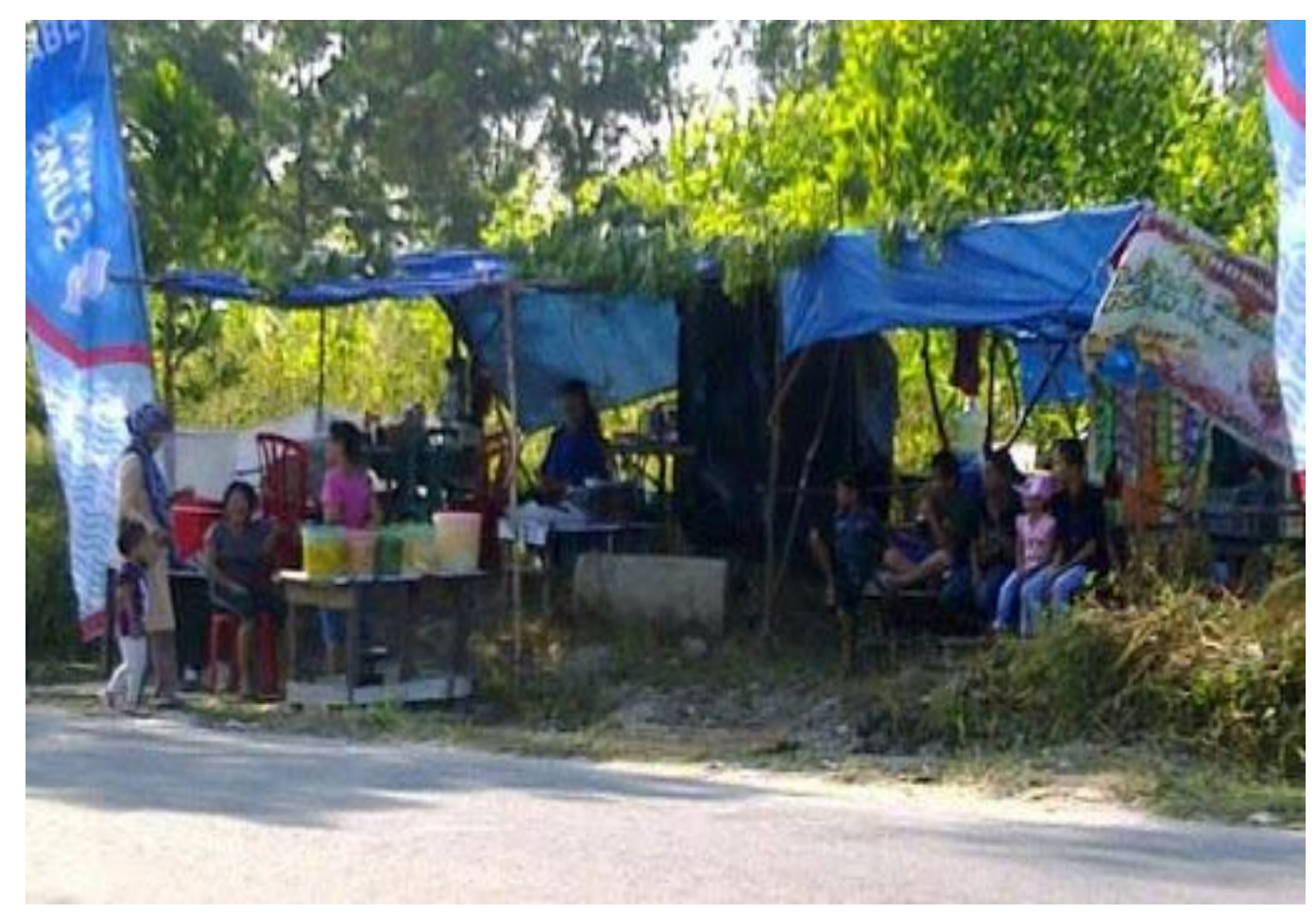

Foto 10 : Pedagang Kaki Lima

(Dokumentasi Ayu, 2015) 